\title{
INVESTIGAÇÃO DO PROCESSO DE METANAÇÃO DE CO EM ÂNODOS DE CÉLULAS A COMBUSTÍVEL PEMFC
}

Dissertação apresentada ao Instituto de Química de São Carlos da Universidade de São Paulo como parte dos requisitos para a obtenção do título de mestre em ciências.

Área de concentração: Físico-Química Orientador: Prof. Dr. Edson A. Ticianelli

\section{Exemplar Revisado}

O exemplar orignal encontra-se em acervo reservado na Biblioteca do IQSC-USP

SÃO CARLOS 
Dedico este trabalho aos meus pais Dalva e José Francisco, por terem acreditado em mim e terem me dado todo o suporte possível e até o então presumivelmente impossível para a realização dos meus sonhos. 


\section{AGRADECIMENTOS}

- Aos meus pais José Francisco e Dalva e minha irmã Tatiane por serem sempre meus companheiros, mentores e exemplo de vida;

- Ao meu orientador, Edson A. Ticianelli, por ter possibilitado a realização conjunta deste trabalho com todo seu apoio profissional e pessoal, pela sua amizade e dedicação;

- Ao Fio (Valdecir A. Paganin) pelas longas discussões, auxílios experimentais, idéias, amizade e pela persistência em "caçar" vazamentos e paciência em suas explicações e quando algo não ia bem;

- Aos colegas e amigos de laboratório, pelos momentos de descontração, paciência com minhas piadas e bons momentos regados a discussões e café, mesmo quando meu humor não estava muito bem estabelecido;

- Aos colegas e amigos de IQSC e USP, por ajudar a dar vida e dinamismo a este ambiente, contribuindo para que a passagem por esta universidade fosse completa, não só academicamente, mas socialmente e fisicamente;

- A todos os amigos de Piracicaba por dar vida aos meus finais de semana e me auxiliar nas mais diversas questões, mesmo estando distante;

- Ao IQSC, pela estrutura para a realização dos experimentos;

- Ao LNLS e LNNano, pela estrutura para realização de medidas de XPS e de TEM;

- À FAPESP, pelo apoio financeiro. 
"Não poríamos a mão no fogo pelas nossas opiniões: não temos assim tanta certeza delas. Mas talvez nos deixemos queimar para podermos ter $e$ mudar as nossas opiniões."

(Friedrich W. Nietzsche) 


\section{RESUMO}

Neste trabalho foi estudada a reação de metanação do $\mathrm{CO}$ em catalisador de Ru/C e sua aplicação em purificação de hidrogênio para utilização em célula a combustível. Tendo como meta a otimização da produção de metano em baixas temperaturas foram preparados materiais de $\mathrm{Ru}_{x} \mathrm{Pd}_{(1-x)} / \mathrm{C}$, que também foram tratados termicamente em atmosfera úmida e redutora. Ao final do estudo com $\mathrm{CO}$, também foi investigado o efeito da presença de $\mathrm{CO}_{2}$ no fluxo de hidrogênio, tal qual num sistema real utilizando-se gás de síntese. Os dados obtidos por espectroscopia de energia dispersiva de Raio-X (EDX) mostraram uma boa correspondência entre as composições teóricas e as obtidas experimentalmente dos catalisadores preparados neste trabalho. Analisando-se os difratogramas de Raio-X (DRX) foi possível observar a presença de fases metálicas principalmente de $\mathrm{Ru}$, observando-se também o aumento da cristalinidade do material, promovido pelo tratamento térmico. Além disso, os tamanhos médios de cristalito (TMC) dos materiais foram obtidos com a equação de Scherrer e situaram-se em torno de $2,5 \mathrm{~nm}$. As micrografias de TEM confirmaram o tamanho reduzido das partículas, mas apontaram para uma baixa dispersão dos materiais sobre o suporte, principalmente no caso do $\mathrm{Ru} / \mathrm{C}$. Com as medidas de XPS foram identificadas espécies de Ru metálico, $\mathrm{Ru}(\mathrm{IV}), \mathrm{Ru}(\mathrm{VII}), \mathrm{RuO}_{x} \mathrm{H}_{\mathrm{y}}$ e $\mathrm{Ru} . \mathrm{xH}_{2} \mathrm{O}$. O tratamento térmico somente afetou a população de espécies do material $\mathrm{Ru} / \mathrm{C}$, que passou a apresentar maior percentual de Ru metálico, em detrimento aos óxidos. Os catalisadores Ru/C e $\mathrm{Ru}_{7} \mathrm{Pd}_{3} / \mathrm{C}$ antes e após o tratamento térmico foram acomodados em filtro de linha gasosa (reator de leito fixo), sendo possível concluir que o tratamento térmico somente promoveu melhora no desempenho metanador para o catalisador Ru/C. Quando utilizados em camada difusora anódica este efeito foi ainda mais pronunciado, sendo observada a produção de $\mathrm{CH}_{4}$ em regime estacionário em Ru/C tratado termicamente quando a temperatura de metanação foi $85^{\circ} \mathrm{C}$. O material mais eficiente foi o de Ru/C após o tratamento térmico, sendo capaz inclusive de hidrogenar seletivamente o $\mathrm{CO}$ na presença de $\mathrm{CO}_{2}$. A melhora no desempenho da célula que utilizou este material foi mais notável a $105^{\circ} \mathrm{C}$, possibilitando a operação com $33 \mathrm{mV}$ de sobrepotencial a 1 A. $\mathrm{cm}^{-2}$ quando alimentada com $\mathrm{H}_{2}$ contendo 75 ppm de $\mathrm{CO}$. 


\section{ABSTRACT}

In this work the $\mathrm{CO}$ methanation reaction over $\mathrm{Ru} / \mathrm{C}$ catalyst and its practical applications for use as hydrogen purifier for low temperature fuel cell anodes were studied. Aiming at optimizing the low temperature methane production, two main procedures were proposed: The use of $\operatorname{Ru}_{x} \mathrm{Pd}_{(1-\mathrm{x})} / \mathrm{C}$ materials and its corresponding thermal treatment of the $\mathrm{Ru} / \mathrm{C}$ catalyst under wet and reductive atmosphere. The effect of the presence of $\mathrm{CO}_{2}$ was then investigated under the same conditions as for $\mathrm{CO}$ in order to establish the catalysts selectivity for the $\mathrm{CO}$ methanation in the presence of $\mathrm{CO}_{2}$, as in a real system using syngas. EDX data showed a good agreement between the expected compositions and that actually obtained for catalysts prepared in this work. DRX spectra have indicated the presence of metallic phases, particularly of $\mathrm{Ru}$, and the increase of the material crystallinity, promoted by the thermal treatment. Furthermore, the materials mean crystallite sizes were obtained by the use of the Scherer equation and they resulted around 2,5 $\mathrm{nm}$ for all samples. TEM micrographs confirmed the small particle size but also showed a poor material dispersion of the metals over the carbon support, especially in the case of Ru/C. XPS measurements have evidenced the presence of ruthenium species such as $\mathrm{Ru}(\mathrm{IV}), \mathrm{Ru}(\mathrm{VII}), \mathrm{RuO}_{\mathrm{x}} \mathrm{H}_{\mathrm{y}}$ and $\mathrm{Ru} \cdot \mathrm{xH}_{2} \mathrm{O}$ in the prepared ruthenium material. The thermal treatment only affected the $\mathrm{Ru}$ species population, showing more metallic ruthenium and less oxides. The $\mathrm{Ru} / \mathrm{C}$ and $\mathrm{Ru}_{7} \mathrm{Pd}_{3} / \mathrm{C}$, prior and after the treatment, were accommodated inside a gas filter, and mass spectrometry investigations indicated that the thermal treatment only increased the methanation performance for the Ru/C catalyst. When used in anodic gas diffusion layer, this improvement was even more pronounced, and resulted in stationary methane production even at $85^{\circ} \mathrm{C}$. The most efficient material for $\mathrm{CO}$ methanation was $\mathrm{Ru} / \mathrm{C}$ thermally treated, that promoted the $\mathrm{CO}$ methanation in a preferable way even when $\mathrm{CO}_{2}$ was present with percentages as high as $25 \%$. The increase of the electrochemical performance of the fuel cell with this catalyst in the diffusion layer was better when at $105^{\circ} \mathrm{C}$. 


\section{LISTA DE ILUSTRAÇÕES}

Figura 1 Célula unitária para o sistema cristalino do $\mathrm{Ru}, \mathrm{HCP}$ ("Hexagonal Close Packing"). a e c são os parâmetros de rede.

Figura 2 Curva analítica para concentração de metano, utilizando-se espectrômetro de massas na saída do compartimento anódico da célula.

Figura 3 Difratogramas de Raio-X obtidos para os materiais: (a) Ru/C (b)Ru/C após tratamento térmico (c) $\mathrm{Ru}_{7} \mathrm{Pd}_{3} / \mathrm{C}$ (d) $\mathrm{Ru}_{7} \mathrm{Pd}_{3} / \mathrm{C}$ após tratamento térmico e (e) RuPd/C.

Figura 4 Espectro de XPS para catalisador de Ru/C (a) como preparado, (b) após tratamento térmico. A região de energia corresponde ao orbital $3 p_{3 / 2}$ do Ru.

Figura 5 Espectro de XPS para catalisador de $\mathrm{Ru}_{7} \mathrm{Pd}_{3} / \mathrm{C}$ (a) como preparado, (b) após tratamento térmico. A região de energia corresponde ao orbital $3 p_{3 / 2}$ do Ru.

Figura 6 Imagens obtidas por TEM para os materiais: (a)Ru/C, (b)Ru/C após tratamento térmico, (c) $\mathrm{Ru}_{7} \mathrm{Pd}_{3} / \mathrm{C}$ e (d) $\mathrm{RuPd} / \mathrm{C} . \quad 50$

Figura 7 Produção de $\mathrm{CH}_{4}$ durante $\mathrm{o}$ revezamento do gás de alimentação anódica de $\mathrm{H}_{2}$ contendo 100 ppm de $\mathrm{CO}$ para $\mathrm{H}_{2}$ puro e de $\mathrm{H}_{2}$ puro para $\mathrm{H}_{2}$ contendo 100 ppm de $\mathrm{CO}$, quando catalisador Ru/C foi utilizado na camada difusora anódica, a $85^{\circ} \mathrm{C}$.

Figura 8 Perfis de produção de $\mathrm{CH}_{4}$ quando troca-se o gás de alimentação anódica de $\mathrm{H}_{2}+100 p p m$ de $\mathrm{CO}$ para $\mathrm{H}_{2}$ puro, utilizando-se $\mathrm{Ru} / \mathrm{C}$ ou $\mathrm{Ru}_{7} \mathrm{Pd}_{3} / \mathrm{C}$ como catalisador na camada difusora anódica.

Figura 9 Perfil de produção de $\mathrm{CH}_{4}$ a $105^{\circ} \mathrm{C}$ em catalisador Ru/C sem tratamento térmico, quando utilizado em CDG.

Figura 10 Perfil de produção de $\mathrm{CH}_{4}$ a $85^{\circ} \mathrm{C}$ em catalisador de Ru/C tratado termicamente e utilizado em CDG.

Figura 11 Perfil de produção de $\mathrm{CH}_{4}$ a $105^{\circ} \mathrm{C}$ em catalisador de $\mathrm{Ru} / \mathrm{C}$ tratado termicamente e utilizado em CDG.

Figura 12 Comparação de curvas de sobrepotencial anódico para camada difusora contendo somente $\mathrm{C}$ e posteriormente $\mathrm{Ru} / \mathrm{C}$, em duas diferentes temperaturas. 
Figura 13 Conversão de $\mathrm{CO}$ a $\mathrm{CH}_{4}$ em Ru/C acomodado num filtro de linha gasosa, em diversas temperaturas e sob fluxo de $\mathrm{H} 2$ contendo $\mathrm{CO}$.

Figura 14 Perfis de conversão de $\mathrm{CO}$ a $\mathrm{CH}_{4}$ em filtro de linha gasosa a $200{ }^{\circ} \mathrm{C}$ para os catalisadores antes e após o tratamento térmico.

Figura 15 Curvas de polarização e de sobrepotencial anódico para células a combustível operando a $85^{\circ} \mathrm{C}$ e empregando Ru/C para a convesão do $\mathrm{CO}$ em $\mathrm{CH}_{4}$.

Figura 16 Curvas de produção de $\mathrm{CH}_{4}$ quando $\mathrm{Ru} / \mathrm{C}$ tratado termicamente foi utilizado em filtro de linha de gases, operando a $200^{\circ} \mathrm{C}$, e o gás de alimentação foi (a) $\mathrm{H}_{2}$ contendo $75 \mathrm{ppm}$ de $\mathrm{CO}$ (b) $\mathrm{H}_{2}$ contendo $25 \%$ de $\mathrm{CO}_{2}$ e (c) 66 $\mathrm{H}_{2}$ contendo $25 \%$ de $\mathrm{CO}_{2}+75 \mathrm{ppm}$ de $\mathrm{CO}$.

Figura 17 Curvas de produção de $\mathrm{CH}_{4}$ quando $\mathrm{Ru} / \mathrm{C}$ tratado termicamente foi utilizado em CDG de ânodo de célula a combustível, operando a $85^{\circ} \mathrm{C}$, e o gás de alimentação anódica foi (a) $\mathrm{H}_{2}$ contendo $75 \mathrm{ppm}$ de $\mathrm{CO}$ (b) $\mathrm{H}_{2}$ contendo $25 \%$ de $\mathrm{CO} 2$ e (c) $\mathrm{H}_{2}$ contendo $25 \%$ de $\mathrm{CO}_{2}+75$ ppm de CO.

Figura 18 Curvas de conversão de $\mathrm{CO}$ a $\mathrm{CH}_{4}$ quando $\mathrm{Ru} / \mathrm{C}$ tratado termicamente foi utilizado em CDG de ânodo de célula a combustível, operando a $105^{\circ} \mathrm{C}$, e o gás de alimentação anódica foi (a) $\mathrm{H}_{2}$ contendo 75 ppm de $\mathrm{CO}$ (b) $\mathrm{H}_{2}$ contendo $25 \%$ de $\mathrm{CO}_{2}$ e (c) $\mathrm{H}_{2}$ contendo $25 \%$ de $\mathrm{CO}_{2}+75 \mathrm{ppm}$ de co.

Figura 19 Curvas de polarização de células a combustível operando a $85^{\circ} \mathrm{C}$ e com camada difusora contendo Ru/C tratado termicamente. Além disso estão representadas também as curvas de polarização obtidas com hidrogênio contendo $\mathrm{CO}$ 70 e também $\mathrm{CO}_{2}$.

Figura 20 Curvas de polarização de células a combustível operando a $105^{\circ} \mathrm{C}$ e com camada difusora contendo Ru/C tratado termicamente. Além disso, estão representadas também as curvas de polarização obtidas com hidrogênio contendo $\mathrm{CO}$ 71 e também $\mathrm{CO}_{2}$. 


\section{LISTA DE TABELAS}

Tabela 1 Principais tipos de células a combustível, conforme classificação pelo eletrólito utilizado e sua faixa de temperatura de operação.

Tabela 2 Dados obtidos via EDX representando a proporção mássica entre os metais e o suporte de Carbono e proporção atômica entre os metais dos catalisadores em estudo. t.t. indica que o material foi tratado termicamente e depois analisado via EDX.

Tabela 3 Planos cristalográficos e seus respectivos ângulos e intensidade de difração para o Ru, de acordo com dados obtidos o JCPDS ("Joint Committee for Powder Diffraction Structure"), ficha número 021258.

Tabela 4 Parâmetros de rede a e c do Ru HCP e tamanho médio de cristalito para os diversos materiais. Os parâmetros a e c também estão comparados com o padrão de Ru. 


$\begin{array}{ll}\text { IEA } & \text { "International Energy Agency" } \\ \text { SOFC } & \text { "Solid Oxide Fuel Cell" } \\ \text { MCFC } & \text { "Molten Carbonate Fuel Cell" } \\ \text { PAFC } & \text { "Phosphoric Acid Fuel Cell" } \\ \text { AFC } & \text { "Alkaline Fuel Cell" } \\ \text { PEMFC } & \text { "Proton Exchange Membrane Fuel Cell" } \\ \text { YSZ } & \text { "Yttria-stabilized zirconia" } \\ \text { NASA } & \text { "National Aeronautics and Space Administration" } \\ \text { ROH } & \text { Reação de Oxidação do Hidrogênio } \\ \text { WGSR } & \text { "Water-Gas Shift Reaction" } \\ \text { RWGSR } & \text { "Reverse Water-Gas Shift Reaction" } \\ \text { PrOx } & \text { "Preferential Oxidation" } \\ \text { t.t. } & \text { Tratamento Térmico } \\ \text { EDX } & \text { "Energy Dispersive X-Ray" } \\ \text { DRX } & \text { Difração de Raio-X } \\ \text { XPS } & \text { "X-Ray Photoelectron Spectroscopy" } \\ \text { TEM } & \text { "Transmission Electron Microscopy" } \\ \text { TMC } & \text { Tamanho Médio de Cristalito } \\ \text { HCP } & \text { "Hexagonal Close Packing" } \\ \text { LNLS } & \text { Laboratório Nacional de Luz Sincrotron } \\ \text { LNNano } & \text { Laboratório Nacional de Nanotecnologia } \\ \text { BF } & \text { "Bright Field" } \\ \text { HAADF } & \text { "High-Angle Annular Dark Field" } \\ \text { EDG } & \text { Eletrodo de Difusão Gasosa } \\ \text { CDG } & \text { Camada de Difusão Gasosa }\end{array}$




\section{LISTA DE SÍMBOLOS}

K

Constante de Scherrer igual a 0.9 (consideração sobre formato dos cristalitos);

$\lambda \quad$ Comprimento de onda da radiação incidente (em $\AA$ )

$\theta$

Ângulo de difração;

$\beta$

Largura da meia altura do pico de difração, aproximado por uma curva pseudo Voigt (rad);

h, k, I Índices de Miller do plano cristalográfico correspondente ao pico de difração utilizado;

d Distância entre dois planos cristalográficos paralelos;

a, c Parâmetros de rede da célula unitária para o sistema cristalino hexagonal compacto;

$\varepsilon \quad$ Eficiência termodinâmica;

$\Delta \mathrm{G} \quad$ Variação da energia livre de Gibbs;

$\Delta \mathrm{H} \quad$ Variação de Entalpia;

$\eta \quad$ Sobrepotencial Anódico;

$\mathrm{E}_{\mathrm{H} 2} \quad$ Potencial da célula a combustível, a uma dada densidade de corrente, quando se utiliza Hidrogênio puro;

$E_{\mathrm{H} 2 / \text { contaminantes }}$ Potencial da célula a combustível, a uma dada densidade de corrente, quando se utiliza Hidrogênio contendo contaminantes. 


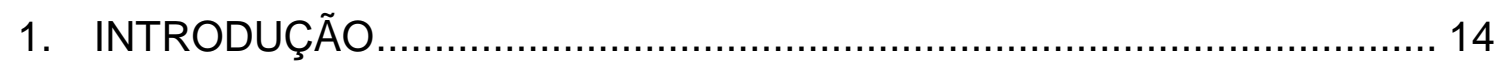

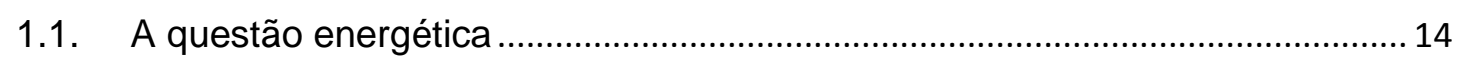

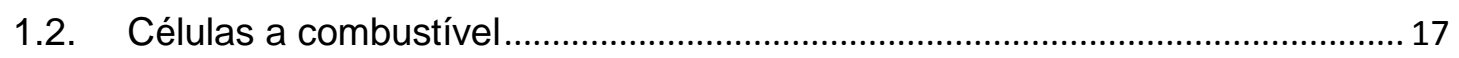

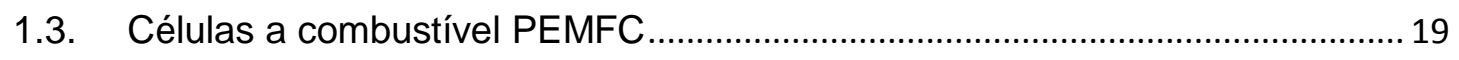

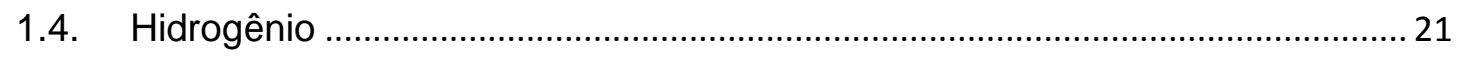

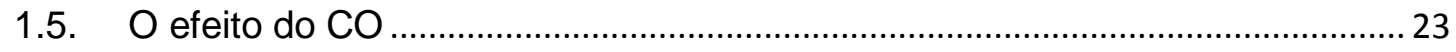

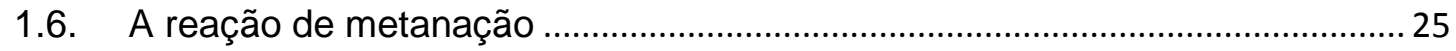

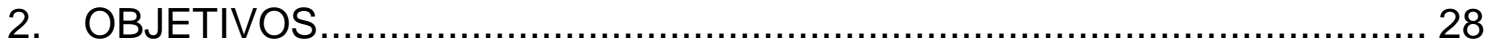

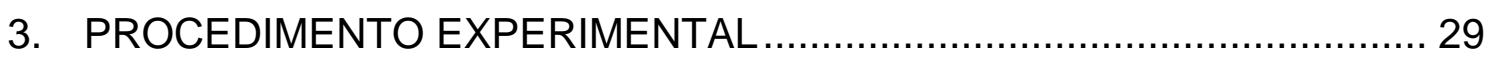

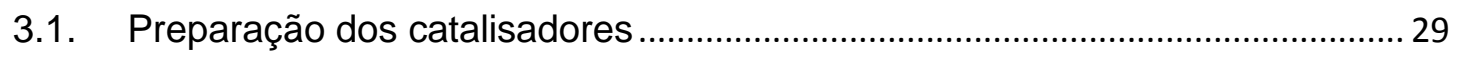

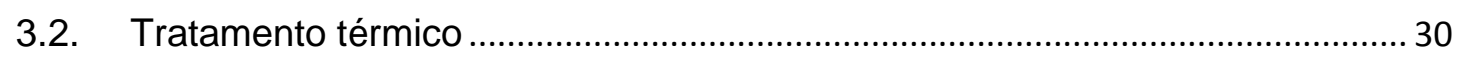

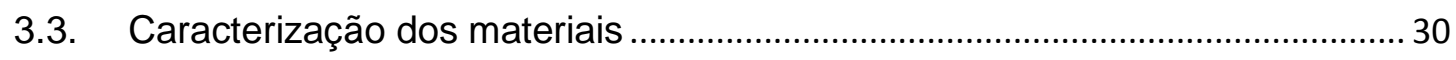

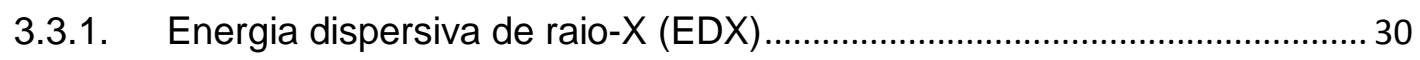

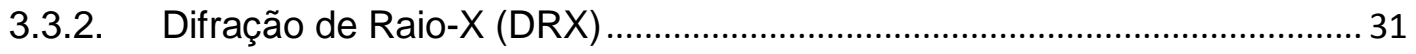

3.3.3. Espectroscopia de Fotoelétrons excitados por Raio-X (XPS) .................... 33

3.3.4. Microscopia Eletrônica de Transmissão (TEM) …………….......................... 34

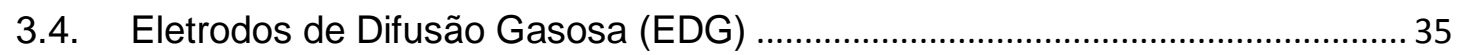

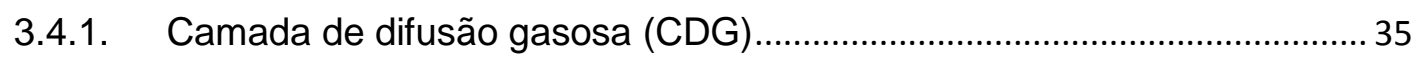

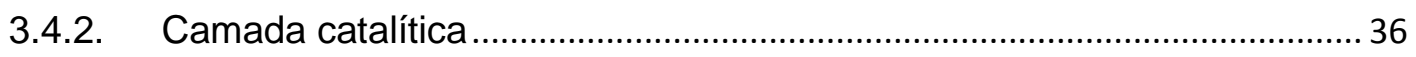

3.5. Preparação do conjunto Membrana-Eletrodos (MEA) ....................................... 37

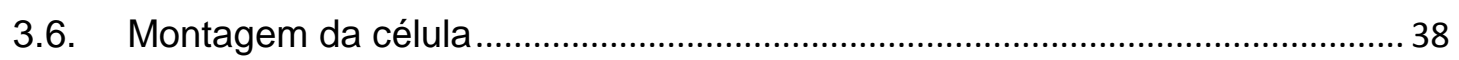

3.7. Acoplamento com o espectrômetro de massas.................................................... 39

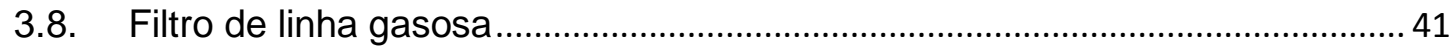

3.9. Curvas polarização em estado estacionário ......................................................... 41

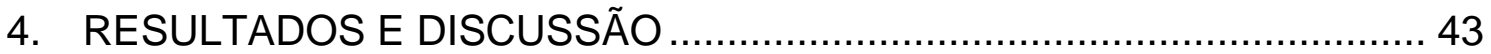

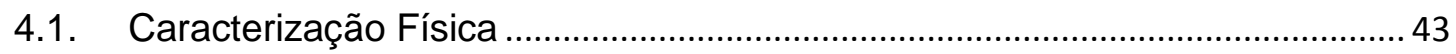

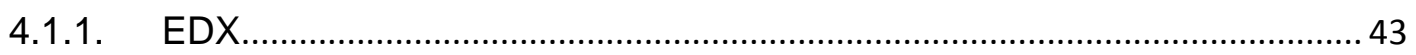

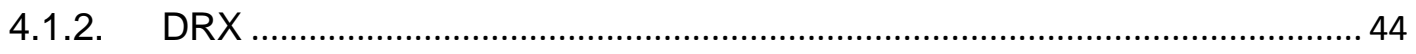

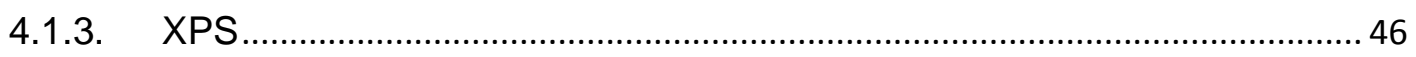

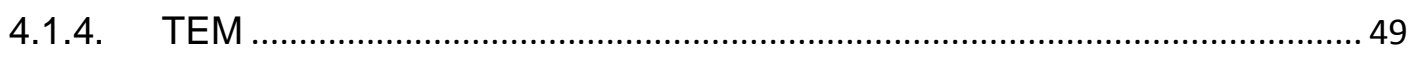

4.2. Camada difusora modificada com $\mathrm{Ru} / \mathrm{C}, \mathrm{Ru}_{7} \mathrm{Pd}_{3} / \mathrm{C}$ e RuPd/C ........................... 51

4.2.1. Reação de metanação............................................................................... 51 
4.2.1.1. Efeito da adição de Pd em Ru/C ............................................................ 51

4.2.1.2. Efeito do aumento da temperatura ......................................................... 56

4.2.2. Curvas de polarização e de sobrepotencial anódico ................................... 59

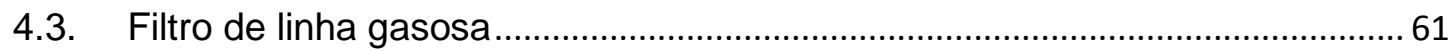

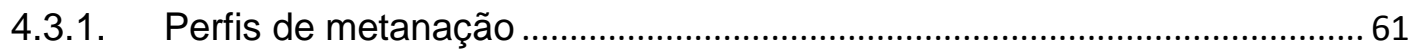

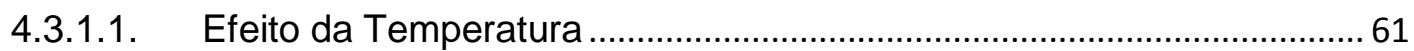

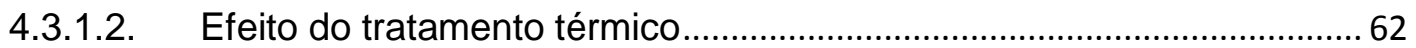

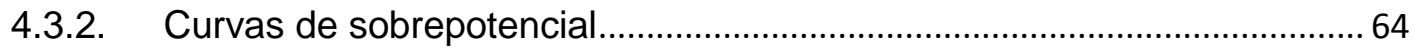

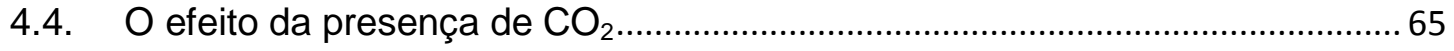

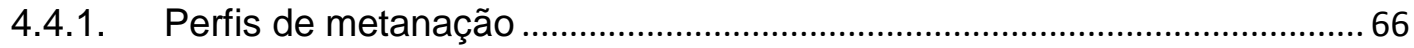

4.4.2. Curvas de Polarização em estado estacionário ........................................... 70

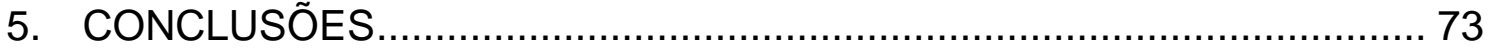

6. REFERÊNCIAS BIBLIOGRÁFICAS ............................................. 74 


\section{INTRODUÇÃO}

\subsection{A questão energética}

Nas últimas décadas têm crescido os debates a respeito das consequências da emissão de gases poluentes na atmosfera, principalmente os óxidos de enxofre, carbono e nitrogênio, liberados durante a queima de combustíveis fósseis. Dentre os efeitos que estes gases produzem quando presentes na atmosfera podem-se destacar: o efeito estufa, cujo principal responsável é o $\mathrm{CO}_{2}$, e que promove uma aceleração no aquecimento do planeta; a chuva ácida, causada pela presença de óxidos de enxofre e de nitrogênio, que se convertem em ácidos sulfúrico e nítrico, produzindo uma precipitação pluviométrica com um pH abaixo do normal, com consequências como acidificação de corpos d'água, danos à vegetação, corrosão de edifícios, etc. ${ }^{[1]}$.

Além da emissão de gases poluentes, a utilização dos combustíveis fósseis apresenta outros empecilhos, podendo-se destacar o fato de suas reservas apresentarem localização geográfica limitada. Apesar disto, sua demanda é global ${ }^{[2]}$, o que conduz a um impacto ambiental e social que inclui não somente extração, mas também o transporte partindo destas poucas regiões produtoras, para todo o planeta, ocasionando eventualmente grandes vazamentos durante estas atividades. As consequências são desastrosas não somente para o meio ambiente, mas também para as pessoas envolvidas direta e indiretamente com a atividade petroleira $^{[3]}$.

No sudeste brasileiro o volume de chuvas no período de outubro/2012 a janeiro/2013 ficou abaixo do esperado, o que trouxe como uma das consequências a diminuição do nível do reservatório das usinas hidrelétricas. Para evitar um possível apagão devido à capacidade reduzida de geração de energia, o Governo Federal colocou em funcionamento usinas termelétricas, que utilizam óleo cru ou gás natural para a produção de energia ${ }^{[4]}$. 
Porém, esta é uma maneira cara, ineficiente e poluidora de produção de energia elétrica, que por estes motivos vem sendo muito debatida no cenário energético mundial. Além dos atuais problemas energéticos já discutidos, é necessária a elaboração de planos de longo prazo para o país, pois o Brasil será sede de grandes eventos mundiais, nomeadamente a copa das confederações em 2013, copa do mundo de futebol em 2014 e olímpiadas em 2016. Estes grandes acontecimentos tendem a alavancar a produção industrial e a atividade comercial nacional, elevando-se também o consumo energético.

Entretanto, os moldes atuais de gerenciamento energético contemplam ou a construção de hidrelétricas, acarretando em danos ambientais e sociais devido às áreas a serem alagadas, ou a utilização de sistemas ultrapassados de produção de energia, como as termelétricas, que se opõe às tendências mundiais e aos tratados de redução da emissão de gases estufa. Portanto, fazem-se necessários investimentos para a viabilização de maneiras alternativas de produção e distribuição de energia elétrica.

Segundo a IEA ${ }^{[5]}$ (International Energy Agency) há previsão de elevação dos subsídios para a utilização de combustíveis renováveis dos atuais U\$\$ 66 bi para U\$ 250 bi até 2035. Além do mais, o preço do barril de óleo cru do tipo "Brent" saltou de U\$\$35 em fevereiro de 2009 para quase U\$\$85 em maio de 2010 e finalmente para $U \$ \$ 117$ em fevereiro de 2013. Esta crescente elevação no preço do barril de petróleo é acompanhada por diversos distúrbios e instabilidades políticas e econômicas em seus países produtores. Como exemplos destes distúrbios, pode-se citar a guerra da Líbia, em 2011, os atuais levantes no Mali e também a guerra civil na Síria. Todo este cenário político-econômico vulnerável aos indicadores econômicos e às instabilidades políticas, além dos impactos ambientais envolvidos nas atividades relacionadas aos combustíveis fósseis, como exposto anteriormente, colocam em questão a viabilidade da continuidade da utilização desta matéria prima, como é feita hoje em dia $^{[5]}$.

Tendo em vista esta situação de oleocracia, diversas alternativas aos combustíveis fósseis vêm sendo desenvolvidas e utilizadas. Uma maneira de reduzir este problema é diversificar as matrizes energéticas, aumentando a parcela de utilização dos combustíveis provenientes de fontes renováveis (dentre eles os 
biocombustíveis) e reduzindo gradativamente a contribuição dos combustíveis fósseis. Além disso, paralelamente a essa mudança na matriz energética, novos métodos de produção de energia devem ser desenvolvidos e implementados, visando-se à máxima eficiência na geração de energia elétrica, aproveitando-se também, se possível, os subprodutos gerados, valendo-se da chamada cogeração. Um exemplo de cadeia produtiva na qual se utiliza a cogeração é a do setor sucroalcooleiro. A energia elétrica necessária para se manter a usina em funcionamento pode ser obtida através da queima do bagaço da matéria prima da cadeia produtiva: a cana-de-açúcar ${ }^{[6]}$.

A utilização dos biocombustíveis promove uma neutralização na emissão do principal gás estufa, $\mathrm{O} \mathrm{CO}_{2}$. Todo o gás carbônico liberado pela queima do combustível será reabsorvido pela planta, podendo ser novamente transformado em combustível através da fotossíntese, num ciclo fechado de produção e consumo de carbono. Além do ciclo do carbono, há também a vantagem da menor emissão de outros poluentes, como óxidos de enxofre e nitrogênio ${ }^{[7]}$.

Os biocombustíveis também se tornaram alvo de grande polêmica, pois para sua produção há a necessidade de utilização de grandes quantidades de água, desmatamento de grandes áreas e produção em monocultura, prática reconhecidamente danosa ao solo pelo esgotamento dos nutrientes e, danosa também à sociedade, pela diminuição na diversidade dos alimentos disponíveis ${ }^{[8,9]}$.

Existem diversas outras maneiras de se obter energia elétrica com um menor impacto ambiental e com alta eficiência, como por exemplo, através da energia solar $^{[10]}$, energia eólica ${ }^{[11]}$, energia geotérmica ${ }^{[12]}$, energia maremotriz ${ }^{[13]}$, energia hidrelétrica ${ }^{[14]}$, energia nuclear ${ }^{[15]}$, etc.. Cada método de obtenção de energia apresenta suas próprias vantagens e desvantagens, tornando-os viáveis para determinadas aplicações e determinadas regiões, de acordo com a disponibilidade de recursos naturais. No Brasil, por exemplo, a maior parte da eletricidade provém de usinas hidrelétricas ${ }^{[14]}$, dada a grande disponibilidade de recursos naturais. Já em países como o Japão, onde há limitações físicas e de recursos naturais, a produção de energia elétrica por usinas nucleares é o método predominante ${ }^{[15]}$. Além destes métodos de geração de energia elétrica, há outro método muito eficiente, que se 
relaciona à utilização de células a combustível, cujo princípio é a conversão da energia química de diversos combustíveis em energia elétrica.

\subsection{Células a combustível}

As células a combustível são dispositivos eletroquímicos que convertem energia química diretamente em energia elétrica, sem promover a combustão. Não há um consenso sobre quem foi o descobridor dos princípios de funcionamento de uma célula a combustível. É postulado que, de maneira independente, o químico alemão Christian Friedrich Schönbein e o inglês Sir William Robert Grove foram os responsáveis pelos primeiros estudos a respeito desta tecnologia ${ }^{[16]}$.

Apesar desta falta de consenso, Grove é comumente tido como o responsável pelo conceito de célula a combustível de hidrogênio. Descobriu que, ao se conectar em série os pares de eletrodos de platina que compunham seu experimento poderia aumentar a diferença de potencial, criando o que ele chamou de bateria de gás. Essa bateria de gás foi caracterizada e estudada com mais profundidade por Ostwald, no final do século XIX. Ostwald proporcionou a compreensão dos processos eletródicos envolvidos na geração de energia por este dispositivo.

O próximo grande progresso nessa tecnologia ocorreu durante o período da segunda grande guerra. Thomas Francis Bacon foi o responsável pelo desenvolvimento da primeira célula a combustível de hidrogênio e oxigênio com aplicações práticas, que foi utilizada pioneiramente em submarinos ingleses.

$\mathrm{Na}$ década de 50 ocorreu mais um grande avanço. A empresa Dupont desenvolveu um material chamado Teflon, um polímero de tetrafluoretileno. Este material, por ser muito resistente à corrosão, proporcionou a criação de sistemas mais eficientes, com melhor vedação e mais duráveis, sendo o material de escolha para a confecção de células a combustível que utilizam eletrólito alcalino.

As primeiras membranas de trocas protônicas surgiram em meados da década de 50. A primeira a ser utilizada foi uma versão sulfonada de poliestireno. Porém, somente no final da década de 1960 foi desenvolvido pela Dupont o Nafion, 
um polímero de fluoretileno sulfonado e que apresenta excelentes propriedades mecânicas, ótima estabilidade química e durabilidade, sendo também um ótimo condutor protônico. Por estes motivos ainda hoje é o material mais utilizado como eletrólito sólido trocador de prótons, conferindo peso reduzido às células a combustível e, portanto, possibilitando o desenvolvimento para utilização em sistemas portáteis, não estacionários e de baixa temperatura de operação ${ }^{[17]}$.

Nas células a combustível, a produção de energia elétrica não se dá por trabalho de expansão, como num motor, mas sim pela utilização da energia das ligações químicas dos reagentes. Por esta razão teoricamente apresenta uma elevada eficiência, reduzindo a quantidade de combustível necessária para produzir a mesma quantidade de energia que um motor a combustão interna ${ }^{[18,19]}$.

Portanto, uma célula a combustível é uma célula eletroquímica, de fato uma célula galvânica, composta pelos compartimentos anódico e catódico, separados por um eletrólito. Em contato com o eletrólito, em cada compartimento, há catalisadores específicos para a quebra das ligações químicas.

Utilizando-se um circuito elétrico externo, os elétrons liberados na quebra das ligações dos reagentes anódicos podem ser utilizados sob a forma de energia elétrica. A eficiência teórica de uma célula a combustível $(\varepsilon)$ é definida pela equação (1), onde $\Delta G$ é a variação da energia livre de Gibbs e $\Delta H$ é a variação de entalpia da reação global:

$$
\varepsilon=\frac{\Delta G}{\Delta H}
$$

A priori qualquer combustível pode ser utilizado para geração de energia. Porém, o que irá definir as características operacionais da célula é o eletrólito utilizado, pois este é o componente que apresenta as maiores restrições, principalmente quanto à temperatura de operação e ao seu peso. Por este motivo, as células a combustível são usualmente caracterizadas de acordo com o eletrólito utilizado. Na Tabela 1 encontram-se os principais tipos de células a combustível com suas características ${ }^{[20]}$. 
Tabela 1: Principais tipos de células a combustível, conforme classificação pelo eletrólito utilizado e sua faixa de temperatura de operação ${ }^{[20]}$.

\begin{tabular}{cll}
\hline \multicolumn{1}{c}{ Tipo } & \multicolumn{1}{c}{ Eletrólito } & \multicolumn{1}{c}{ Temperatura ${ }^{\circ} \mathrm{C}$ ) } \\
\hline Óxido Sólido (SOFC) & $\mathrm{YZS}$ & $650-1000$ \\
Carbonato Fundido (MCFC) & $\mathrm{Li}, \mathrm{Na}, \mathrm{KCO}_{3}$ & $600-700$ \\
Ácido Fosfórico (PAFC) & $\mathrm{H}_{3} \mathrm{PO}_{4}$ & $170-210$ \\
Alcalina (AFC) & $\mathrm{NaOH}, \mathrm{KOH}$ & $50-200$ \\
Membrana de Troca Protônica (PEMFC) & Nafion ${ }^{\circledR}$ & $50-125$ \\
\hline
\end{tabular}

O auge da popularidade das células a combustível foi atingido em meados da década de 1970, com a utilização de células a combustível de eletrólito alcalino nas missões espaciais Apollo da NASA, agência espacial americana. Foi durante este período que ocorreram evoluções em diversos aspectos e que são refletidos até os dias de hoje, principalmente com as células a combustível de eletrólito polimérico sólido, como a utilização de eletrodos de difusão gasosa e consequente redução na quantidade de platina utilizada. Não somente as células de eletrólito polimérico evoluíram, mas muitos sistemas estacionários de células a combustível foram aperfeiçoados, possibilitando a utilização de células a combustível de carbonato fundido, ácido fosfórico e de óxido sólido como matriz energética principal da sede de grandes multinacionais ${ }^{[21]}$.

\subsection{Células a combustível PEMFC}

Dos diversos tipos células a combustível listadas acima, uma que vem ganhando grande destaque tanto em pesquisas quanto no desenvolvimento de sistemas comercializáveis é a célula a combustível de membrana de troca protônica, conhecida por PEMFC ("Proton Exchange Membrane Fuel Cell"). Dentre os diversos tipos de membranas trocadoras de prótons, a membrana de Nafion ${ }^{\circledR}$ (DuPont), um tipo de politetrafluoretileno sulfonado, é a que apresenta uma maior amplitude de aplicabilidade e que vem recebendo grande atenção em centros de pesquisa e desenvolvimento de todo o mundo ${ }^{[22]}$. 
Nas últimas décadas a miniaturização foi um dos objetivos principais da indústria de tecnologia, refletindo-se na criação de novos equipamentos portáteis. Porém, para acompanhar esta mudança, novas técnicas e métodos de gerenciamento de energia foram desenvolvidos para estes dispositivos. Além de necessitarem reduzir seu tamanho e peso, mantendo ou até mesmo aumentando sua capacidade de armazenamento de carga, as baterias passaram a ter necessidade de um maior número de ciclos de carga e descarga ${ }^{[23]}$, fatos que tem sido cada vez mais aprimorados.

Como alternativa às baterias, tem-se estudado a utilização de células a combustível de eletrólito polimérico. A faixa operacional de temperatura destas células abrange desde $30^{\circ} \mathrm{C}$ até $150{ }^{\circ} \mathrm{C}$. São muito leves e compactas (a membrana apresenta espessura micrométrica) e proporcionam ótimas densidades de potência, graças à elevada condutividade iônica deste polímero ${ }^{[24]}$.

Os combustíveis mais investigados em células de polímero sólido são, principalmente, álcoois de cadeias curtas (metanol, etanol, etc.) e o hidrogênio. Em princípio, o metanol e o etanol podem ser utilizados tanto diretamente na célula quanto podem passar primeiramente por uma unidade de reforma catalítica, onde são convertidos em hidrogênio (que será de fato o combustível da célula) e $\mathrm{CO}_{2}{ }^{[25]}$ Apesar de estes serem líquidos e, portanto, apresentarem maior densidade energética, existem alguns problemas relacionados com sua utilização.

O metanol é um combustível muito volátil, inflamável e cuja chama não apresenta coloração, representando um potencial risco de acidentes. Além disso, sérios problemas de saúde estão relacionados com sua manipulação inadequada, que vão desde a cegueira até a morte, quando ingerido. Sua desvantagem quando utilizado em células a combustível é que sua oxidação envolve um intermediário fortemente ligado ao catalisador, inativando-o e diminuindo a eficiência do dispositivo $^{[26]}$.

O etanol apresenta uma toxicidade e periculosidade muito menor do que a do metanol. Além disso, atualmente é muito utilizado como combustível para motores a combustão interna, apresentando, portanto, uma rede de distribuição préestabelecida. Sua oxidação completa em células a combustível forneceria um total 
de 12 elétrons. Porém, mesmo o melhor catalisador existente para oxidação de etanol não é capaz de converter eletroquimicamente todo o combustível a $\mathrm{CO}_{2}$, rota com maior número de elétrons ${ }^{[27-29]}$. A maior parte do combustível é convertida a ácido acético, liberando uma quantidade significativamente menor de elétrons, além dos intermediários gerados que, assim como no caso do metanol, podem inativar o catalisador utilizado para a oxidação. O esquema 1 ilustra o mecanismo complexo de oxidação do etanol ${ }^{[30]}$.

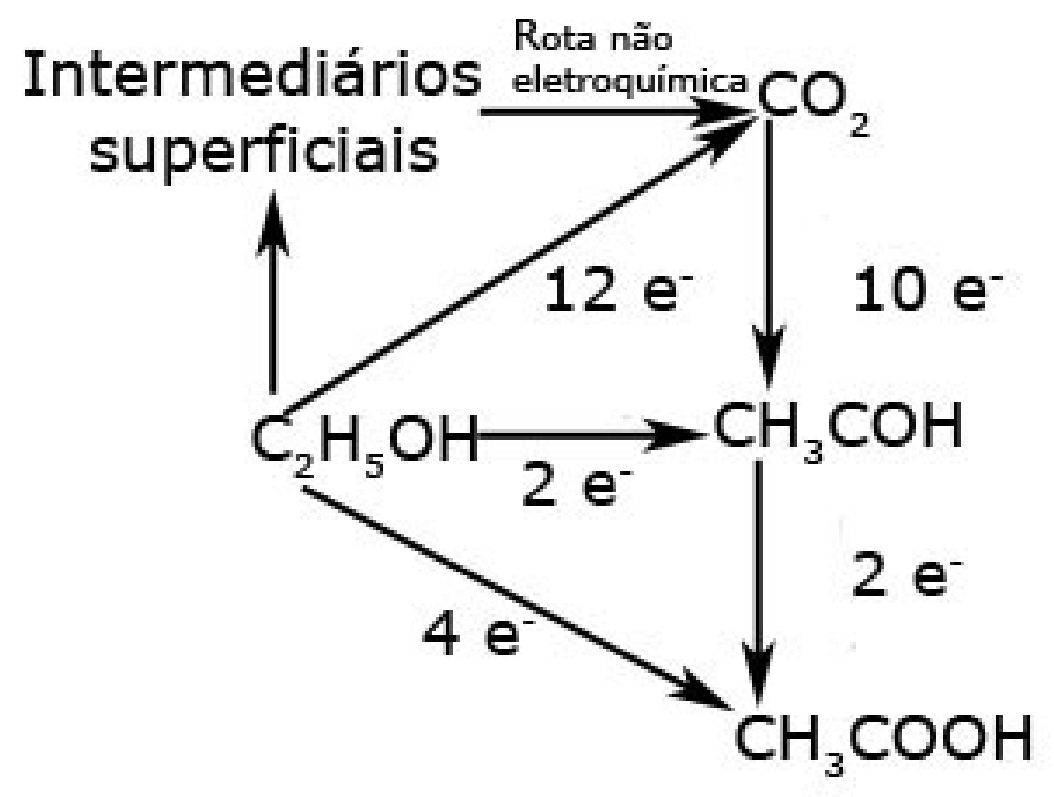

Esquema 1: Possíveis reações paralelas de oxidação do etanol numa célula a combustível do tipo PEM

\subsection{Hidrogênio}

O Hidrogênio é o elemento mais abundante do universo, correspondendo a aproximadamente $75 \%$ da massa total. Foi o alquimista Paracelso, no século XVI, o responsável pela produção do hidrogênio pela primeira vez, ao promover a reação entre ácidos fortes e metais. Porém, somente no século XVIII Cavendish descobriu que o hidrogênio era inflamável e que sua combustão produzia água, denominando o gás como "ar inflamável"[31]. 
A primeira grande utilização de hidrogênio em larga escala ocorreu no início do século $X X$, quando o gás foi utilizado para encher grandes balões de transporte, os chamados dirigíveis. Por quase quarenta anos o transporte de pessoas foi realizado sem nenhum incidente, inclusive em voos transatlânticos. Porém, em 1937, o dirigível Hindenburg se incendiou e ficou completamente destruído, impondo o fim da utilização de hidrogênio para esta finalidade. Após este acidente a utilização e manipulação de hidrogênio passaram a ser visualizados sempre como uma atividade perigosa.

Industrialmente, existem inúmeros processos em que o hidrogênio é utilizado. Podem-se destacar o processo de produção de amônia, o craqueamento de hidrocarbonetos, a hidrogenação de ácidos graxos, produção de metanol, dentre outras. Pode ser produzido de diversas maneiras, porém, industrialmente, é comumente obtido através da reforma catalítica de álcoois de baixo peso molecular, como, por exemplo, metanol, e da reforma catalítica do metano ${ }^{[32]}$.

O Hidrogênio, apesar de ser muito inflamável, apresenta um elevado coeficiente de difusão, o que o torna menos perigoso que outros combustíveis líquidos, pois dificilmente acumula-se em quantidades significativas quando ocorre um vazamento. Além disso, não apresenta riscos à saúde. A vantagem de sua utilização em células a combustível está no fato de que, por ser uma molécula muito simples, sua taxa de oxidação é elevada e não apresenta intermediários que inativam o catalisador, como no caso do etanol, metanol e outros combustíveis mais complexos que apresentam diversas rotas de oxidação ${ }^{[30]}$. Um fator de destaque é que, ao contrário do metanol e etanol, que produzem $\mathrm{CO}_{2}$ como produto da oxidação completa, o hidrogênio produz somente água (Reação 1), tornando-o um combustível extremamente limpo e de grande interesse ambiental.

$$
2 \mathrm{H}_{2}+\mathrm{O}_{2} \rightarrow 2 \mathrm{H}_{2} \mathrm{O}
$$

Reação 1: Reação global de oxidação de hidrogênio, na presença de $\mathrm{O}_{2}$ 
Dentre alguns dos problemas envolvidos na utilização do hidrogênio podemse destacar a dificuldade de armazenamento e transporte ${ }^{[30,33,34]}$. Por ser um gás de difícil liquefação, grandes tanques pressurizados são necessários para armazenar quantidades apreciáveis de combustível. Este é um fator que torna seu transporte mais perigoso e dispendioso, aumentando o peso dos tanques de armazenamento. Outra dificuldade está relacionada com a obtenção de hidrogênio com pureza suficiente para ser utilizado na célula. O hidrogênio que é comercializado com finalidade de combustível normalmente é produzido através da reforma catalítica de álcoois, gás natural, ácidos carboxílicos e outros combustíveis de baixa massa molecular ${ }^{[35]}$. Obtido desta maneira o combustível contém $20-25 \%$ de $\mathrm{CO}_{2}$ e também certa quantidade de $\mathrm{CO}$, tipicamente entre 0,5 a $1 \%{ }^{[36]}$.

\subsection{O efeito do $\mathrm{CO}$}

Em células a combustível de baixa temperatura, um catalisador formado por nanopartículas de Pt dispersas em carbono de alta área superficial $(\mathrm{Pt} / \mathrm{C})$ é o mais utilizado, por ser muito eficiente para a reação de oxidação do hidrogênio (ROH) e também para a reação de redução do oxigênio (RRO). Este material, quando utilizado no ânodo, é suscetível ao envenenamento pelo CO presente no hidrogênio, quando proveniente de reforma catalítica ${ }^{[37]}$. O CO liga-se de maneira não reversível ao sítio de Pt onde ocorre a oxidação de $\mathrm{H}_{2}$, bloqueando o principal mecanismo de fornecimento de elétrons à célula e, assim, reduz drasticamente seu desempenho, mesmo quando presente em quantidades tão reduzidas quanto 10 ppm ${ }^{[38]}$.

Para mitigar este problema uma das abordagens é tornar o catalisador de $\mathrm{Pt}$ mais tolerante à presença de $\mathrm{CO}$, através da inserção de um segundo metal no retículo cristalino da $\mathrm{Pt}$, formando assim uma liga metálica do tipo $\mathrm{PtM} / \mathrm{C}$, sendo $\mathrm{M} \mathrm{o}$ segundo metal. Diversos metais vêm sendo estudados, como o Pd, Mo, W, Ru, $\mathrm{Co}^{[39-41]}$. De maneira geral, a tolerância ao CO nessas ligas ocorre principalmente por duas vias: Efeito eletrônico e Mecanismo bifuncional ${ }^{[42]}$, como descritos a seguir. 
O efeito eletrônico é baseado na maior afinidade eletrônica que o segundo metal apresenta em relação à Pt. Portanto, atua removendo densidade eletrônica do metal ativo, diminuindo a força da retrodoação m entre o CO e a Pt. Esta menor força de ligação reflete-se no menor recobrimento superficial de CO sobre a platina, aumentando, portanto, o número de sítios ativos para a oxidação do hidrogênio ${ }^{[42,43]}$.

No mecanismo bifuncional, o segundo metal da liga deve ser menos nobre que a Pt. Desta maneira, oxida-se em menores potenciais, produzindo espécies superficiais oxigenadas, que diminuem a energia de ativação para a oxidação do CO, promovendo sua remoção dos sítios ativos da Pt, como ilustrado no esquema abaixo. Para a platina pura, em condições ambientes, a formação dessas espécies oxigenadas não ocorre em potenciais menores que $700 \mathrm{mV}$. Quando há a presença do segundo metal, este potencial pode ser reduzido para valores tão baixos quanto $200 \mathrm{mV}^{[44]}$.

$$
\begin{gathered}
\mathrm{CO}+\mathrm{S} \leftrightharpoons \mathrm{CO}-\mathrm{S} \\
\mathrm{S}+\mathrm{H}_{2} \mathrm{O} \leftrightharpoons \mathrm{S}-\mathrm{OH}+\mathrm{H}^{+}+e^{-} \\
S-\mathrm{OH}+\mathrm{S}-\mathrm{CO} \rightarrow 2 \mathrm{~S}+\mathrm{CO}_{2}+H^{+}+e^{-}
\end{gathered}
$$

Esquema 2: Envenenamento por CO (2), formação de espécies oxigenadas sobre a superfície catalítica (3), oxidação irreversível do CO adsorvido (4)

A oxidação do CO sobre estes catalisadores, no ambiente da célula a combustível, tem como produto o $\mathrm{CO}_{2}$. Outra maneira de se reduzir os problemas ocasionados pela presença de $\mathrm{CO}$ no hidrogênio é a sua oxidação não eletroquímica. Alguns catalisadores promovem a chamada reação de deslocamento gás-água (WGSR, do inglês "Water-Gas Shift Reaction", sendo sua reação reversa denominada RWGSR), resumidamente apresentada na Reação 5. 


$$
\mathrm{CO}+\mathrm{H}_{2} \mathrm{O} \leftrightharpoons \mathrm{H}_{2}+\mathrm{CO}_{2}
$$

Reação 5: Reação de deslocamento gás-água (WGSR, do inglês "Water-Gas Shift Reaction")

Diferentemente da eletroxidação do CO, a oxidação por intermédio da WGSR não necessita de aplicação de diferença de potencial para ocorrer. Portanto, catalisadores da WGSR são mais desejáveis de serem utilizados em células a combustível para a remoção do $\mathrm{CO}$, pois o fato de não necessitarem de corrente elétrica para oxidar o CO diminui a utilização de energia gerada pela célula, aumentando a eficiência do dispositivo.

Porém, como $\mathrm{O} \mathrm{CO}_{2}$ se encontra presente no gás de reforma em grandes quantidades, esta reação pode ser desfavorecida, pois a elevada pressão parcial de $\mathrm{CO}_{2}$ e de $\mathrm{H}_{2}$ promove a reversão da reação (5), aumentando a quantidade de $\mathrm{CO}$ adsorvida $^{[37]}$.

Como solução para este problema neste trabalho é proposta a utilização da reação de metanação do $\mathrm{CO}^{[45-52]}$, apresentada resumidamente abaixo.

$$
\mathrm{CO}+3 \mathrm{H}_{2} \leftrightharpoons \mathrm{CH}_{4}+\mathrm{H}_{2} \mathrm{O}
$$

Reação 6: Metanação do CO

\subsection{A reação de metanação}

Nos últimos anos a reação de metanação, tanto de $\mathrm{CO}$ quanto de $\mathrm{CO}_{2}$, vem recebendo muita atenção ${ }^{[48,53]}$. Em parte isso se deve às preocupações com a remoção do $\mathrm{CO}_{2}$ da atmosfera, pois, apesar de o $\mathrm{CH}_{4}$ promover mais o efeito estufa do que $\mathrm{O}_{2}$, ele pode ser reutilizado como combustível, criando assim um ciclo de queima de metano e produção de $\mathrm{CO}_{2}$, e reciclagem para metano, que será novamente utilizado. Em células a combustível, o principal interesse é a metanação do CO para redução do envenenamento do catalisador de Pt/C. 
Entretanto, os catalisadores que realizam metanação de $\mathrm{CO}_{2}$ normalmente também promovem a redução de $\mathrm{CO}$, e vice-versa. O que difere os materiais é a seletividade frente à esta reação ocorrer com o reagente $\mathrm{CO}$ ou $\mathrm{CO}_{2}^{[53]}$. O mais desejável para aplicações práticas de uma célula a combustível é que seja promovida somente a reação de metanação do $\mathrm{CO}$, pois a redução do $\mathrm{CO}_{2}$ envolve a participação de mais moléculas de hidrogênio, consumindo mais do combustível, com a finalidade de limpá-lo. Porém, há também a possibilidade da geração de hidrogênio in situ, promovendo, por exemplo, a eletrólise da água e reduzindo assim a utilização do combustível. A reação 7 apresenta resumidamente a redução de $\mathrm{CO}_{2}$ a metano.

$$
\mathrm{CO}_{2}+4 \mathrm{H}_{2} \leftrightharpoons \mathrm{CH}_{4}+2 \mathrm{H}_{2} \mathrm{O}
$$

Reação 7: Metanação do $\mathrm{CO}_{2}$

A principal vantagem de se propor a reação de metanação para ser utilizada como mecanismo de tolerância ao $\mathrm{CO}$ em células a combustível é o fato de o produto $\left(\mathrm{CH}_{4}\right)$ não inutilizar sítios reacionais para a oxidação de hidrogênio sobre o catalisador de platina e também de que em condições de operação de célula, $\mathrm{CH}_{4}$ não é produzido eletroquimicamente, não ocorrendo, portanto, o acoplamento de reações que envolvem metano e CO, a exemplo do que ocorre entre a WGSR e a produção eletroquímica de $\mathrm{CO}_{2}$. Ademais, o metano gerado pode ser reaproveitado para combustão direta ou passar por reforma catalítica para produzir mais hidrogênio e realimentar a célula.

Diversos catalisadores têm sido estudados com a finalidade de conversão de $\mathrm{CO}$ em $\mathrm{CH}_{4}$, principalmente a partir do gás de síntese $\left(\mathrm{H}_{2}\right.$ contendo $\left.\mathrm{CO}\right)$. Dentre eles, destacam-se o $\mathrm{Ru}, \mathrm{Co}, \mathrm{Ni}, \mathrm{Rh}^{[46]}$. Há também pesquisas recentes relacionadas com a redução do CO presente em hidrogênio proveniente de reforma catalítica, exclusivamente com a finalidade de limpeza do gás de alimentação de células a combustível ${ }^{[42,51,54]}$.

Grande parte das pesquisas envolvendo a reação de metanação e sua utilização em células a combustível está focada principalmente no desenvolvimento 
de unidades pré-célula para limpeza do gás, similarmente ao que é feito utilizandose a oxidação preferencial do $\mathrm{CO}(\operatorname{PrOx})^{[48,50,51]}$, pois mesmo os melhores catalisadores já estudados apresentam uma produção de metano próxima a $6 \%$ em temperaturas tão altas quanto $480 \mathrm{~K}^{[51,54]}$. Utilizada desta maneira, a reação de metanação necessita de um controle operacional maior, haja visto que a temperatura e a pressão da unidade metanadora devem ser diferentes daquela normalmente utilizada na célula, a fim de se obter uma produção satisfatória de metano que possibilite a remoção eficiente do CO.

Recentemente foi observada a produção de metano em uma célula a combustível operando a $85{ }^{\circ} \mathrm{C}$, quando alimentada com $\mathrm{H}_{2}$ contendo 100 ppm e utilizando catalisador $\mathrm{PtRu} / \mathrm{C}^{[42]}$. Entretanto, neste caso, a produção de metano ocorreu somente em regime transiente, ou seja, quando o gás de alimentação foi trocado de $\mathrm{H}_{2}$ puro para $\mathrm{H}_{2}$ contendo 100 ppm de $\mathrm{CO}$ ou vice-versa. Quando operada com alimentação contínua de $\mathrm{H}_{2}$ contendo 100 ppm de CO não foi observada a produção de metano.

A produção contínua de metano a baixas temperaturas é de grande interesse, pois conforme metano é produzido, CO é removido do fluxo de hidrogênio, reduzindo a pressão parcial deste veneno catalítico e, portanto, o grau de recobrimento superficial do catalisador de Pt por CO. Porém, não há relatos na literatura a respeito da utilização da reação de metanação in situ e contínua, ou seja, nas condições de operação de uma célula ( $85^{\circ} \mathrm{C}$ e 1 bar). Aplicada desta maneira, a metanação no interior da célula possibilitaria a confecção de dispositivos compactos e simples, sem necessidade de mais unidades de processamento do gás, diminuindo, portanto, os custos operacionais desta tecnologia. 


\section{OBJETIVOS}

Levando em consideração as observações acima, o presente trabalho apresenta como objetivo o desenvolvimento e caracterização de catalisadores bimetálicos de $\mathrm{Ru}$ e $\mathrm{Pd}$, na forma de $\mathrm{Pd}_{\mathrm{x}} \mathrm{Ru}_{\mathrm{y}} / \mathrm{C}$ submetendo-os posteriormente a tratamento térmico, para a utilização em camadas difusoras de ânodos de células a combustível alimentadas com hidrogênio contendo 100 ppm de CO. Espera-se assim que ocorra uma limpeza no hidrogênio afluente da célula através da promoção da reação de metanação do CO em regime contínuo.

Após a identificação do material mais ativo e das melhores condições para a ocorrência da reação de metanação, novos testes foram realizados com a adição de $\mathrm{CO}_{2}$ no hidrogênio de alimentação da célula, visando mimetizar a composição do gás proveniente de reforma catalítica. Com a utilização destes catalisadores de metanação procura-se obter um sistema de geração de energia mais tolerante às impurezas presentes no hidrogênio proveniente de reforma catalítica, diminuindo os custos relativos à aquisição de combustível de alta pureza. 


\section{PROCEDIMENTO EXPERIMENTAL}

\subsection{Preparação dos catalisadores}

Os catalisadores foram preparados pela co-redução dos precursores metálicos, impregnados em carbono, pelo método do formiato de sódio ${ }^{[55]}$. Abaixo se encontra brevemente descrito o método de preparação.

O suporte catalítico utilizado foi pó de carbono finamente dividido de alta área superficial (C Vulcan, XC-72R Cabot ${ }^{\circledR}$ ), previamente tratado a $850{ }^{\circ} \mathrm{C}$ sob atmosfera de argônio durante 5 h, visando a eliminação das impurezas possivelmente presentes. Os precursores metálicos utilizados foram $\mathrm{RuCl}_{3} \cdot \mathrm{xH}_{2} \mathrm{O}$ (Aldrich, 99,98\%) e $\mathrm{PdCl}_{2}$ (Alfa Aesar, 99,9\%), com os quais foi preparada uma solução aquosa com quantidades adequadas de cada sal, visando obterem-se catalisadores com 40\% em massa de metais em relação ao carbono e com proporção atômica entre os metais como seguem: $100 \% \mathrm{Ru}, \mathrm{Ru}_{7} \mathrm{Pd}_{3}$ e $\mathrm{Ru}_{5} \mathrm{Pd}_{5}$.

À quantidade adequada de pó de carbono $(60 \%$ da massa total do catalisador) foi adicionada solução de formiato de sódio com uma concentração de 0,5 molL $^{-1}$ e em quantidade suficiente para reduzir os precursores metálicos a serem adicionados. $\mathrm{O}$ pH então foi ajustado para 12 através da adição de $\mathrm{NaOH}$ e a suspensão resultante foi agitada mecanicamente e em ultrassom por 45 minutos, de maneira a obter-se a melhor dispersão do carbono na solução de formiato. Após a homogeneização esta suspensão foi mantida em banho-maria a $80^{\circ} \mathrm{C}$ sob agitação mecânica e, previamente à adição dos precursores metálicos, foi desaerada pelo borbulhamento de Argônio durante 10 minutos.

A adição dos precursores foi feita gota a gota, com hidrogênio borbulhando na dispersão de carbono. Após aproximadamente $1 \mathrm{~h}$ de adição o sistema foi mantido em agitação e atmosfera de $\mathrm{H}_{2}$ por mais $1 \mathrm{~h}$, depois da qual a suspensão foi filtrada ainda quente, utilizando-se filtro de membrana de politetrafluoretileno. Após a filtração e subsequentes lavagens com água, a torta obtida foi seca a $90^{\circ} \mathrm{C}$ durante 
$2 \mathrm{~h}$, depois das quais o pó resultante foi armazenado para futuro tratamento e/ou utilização.

\subsection{Tratamento térmico}

Os materiais de $\mathrm{Ru} / \mathrm{C}$ e de $\mathrm{Ru}_{7} \mathrm{Pd}_{3} / \mathrm{C}$ foram submetidos a tratamento térmico em atmosfera de hidrogênio saturada com água, similarmente ao descrito na literatura $^{[56,57]}$. O tratamento térmico consistiu em submeter o catalisador à temperatura de $150{ }^{\circ} \mathrm{C}$ sob fluxo de hidrogênio saturado com água, a 4.8 bar. Esta configuração foi mantida durante $5 \mathrm{~h}$, após as quais o material foi novamente seco a $90{ }^{\circ} \mathrm{C}$ e armazenado para futura preparação de camada difusora e utilização em filtro.

\subsection{Caracterização dos materiais}

Os materiais obtidos após a síntese e também após tratamento em atmosfera de água e hidrogênio foram caracterizados pelas técnicas de Energia Dispersiva de Raio-X (EDX), Difração de Raio-X (DRX), Espectroscopia Fotoeletrônica de Raio-X (XPS) e Microscopia Eletrônica de Transmissão (TEM), como descrito abaixo.

\subsubsection{Energia dispersiva de raio-X (EDX)}

Para a obtenção da proporção mássica entre o carbono e os metais e também a proporção atômica entre Ru e Pd, foi utilizada a técnica de EDX. ${ }^{[40,58]}$. O equipamento utilizado foi um espectrômetro Zeiss-Leica/440 com detector de SiLi. As amostras foram enviadas para análise em pastilhas de 1,6 mm de diâmetro, preparadas pela maceração do catalisador (aproximadamente $30 \mathrm{mg}$ ) com uma emulsão de Teflon com concentração mássica 4\% e afixadas em um suporte com 
cola de prata. Foram obtidas as composições de 5 regiões da amostra, sendo apresentada somente a média desses valores como o resultado.

\subsubsection{Difração de Raio-X (DRX)}

A técnica de difração de Raio-X foi utilizada com a finalidade de se identificar as fases metálicas presentes e caracterizar os materiais, através do cálculo de tamanho médio de cristalito e da obtenção dos parâmetros de rede para os metais no catalisador. $^{[59,60]}$ As medidas foram realizadas num difratômetro URD-6 Carl Zeiss-Jena, a uma velocidade de varredura de 1 grau por minuto, entre $2 \theta$ de 20 a 100 graus. A radiação incidente foi a da banda $\mathrm{KaCu}$, com comprimento de onda igual a $1,5406 \AA$.

\subsubsection{Cálculo do tamanho médio de cristalito}

O tamanho médio dos cristalitos (TMC) das partículas metálicas nos catalisadores foi calculado utilizando-se a equação de Debye-Scherrer, apresentada na Equação 2.

$$
T M C=\frac{10 \cdot K \lambda}{\beta \cos \theta}
$$

onde:

TMC: tamanho médio dos cristalitos(em nm), na direção do plano de difração;

$\mathrm{K}$ : constante de proporcionalidade igual a 0.9 (consideração sobre formato dos cristalitos) ${ }^{[59,60]}$;

$\lambda$ : comprimento de onda da radiação incidente (em $\AA$ );

$\theta$ : ângulo de difração; 
$\beta$ : largura da meia altura do pico de difração, aproximado por uma curva pseudo Voigt (rad).

O pico de difração utilizado para o cálculo do TMC foi o equivalente à reflexão na face (220) do Ru, pois foi o pico mais simétrico, com uma boa intensidade e que se encontra mais distante dos outros picos no difratograma, apresentando, portanto, menores interferências.

\subsubsection{Cálculo dos parâmetros de rede}

O Ru metálico apresenta estrutura cristalina com sistema de empacotamento hexagonal compacto (HCP). Portanto, sua célula unitária pode ser descrita por dois parâmetros de rede, denominados comumente por a e c, como ilustrado na Figura 1.

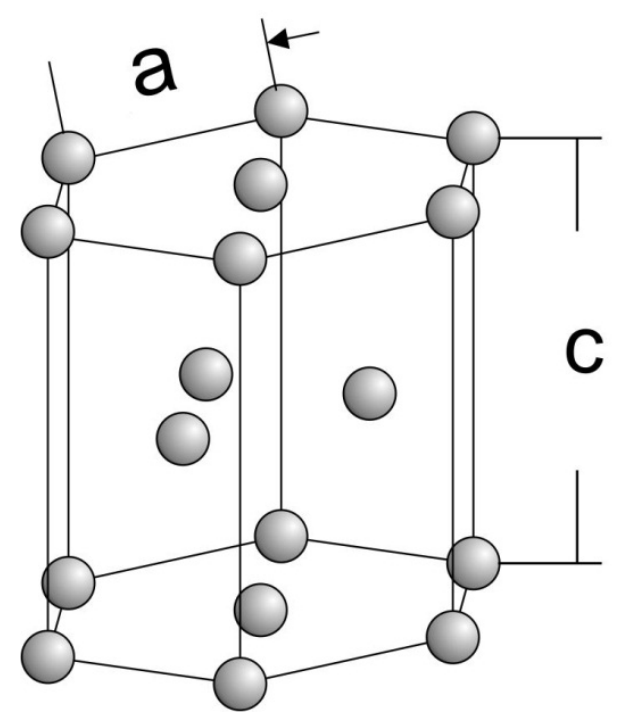

Figura 1: Célula unitária para o sistema cristalino do Ru, HCP ("Hexagonal Close Packing"). a e c são os parâmetros de rede.

Para a obtenção experimental destes parâmetros, é necessária a utilização de duas equações: A equação da Lei de Bragg e a equação para a distância entre dois planos de difração paralelos, no sistema hexagonal compacto, apresentadas abaixo: 


$$
\begin{gathered}
\lambda=2 d \sin \theta \\
\frac{1}{d^{2}}=\frac{4}{3} \frac{h^{2}+h k+k^{2}}{a^{2}}+\frac{l^{2}}{c^{2}}
\end{gathered}
$$

Sendo que:

$\lambda$ : comprimento de onda da radiação incidente (em Å);

h, k, I: Índices de Miller do plano cristalográfico correspondente ao pico de difração utilizado;

d: distância entre dois planos cristalográficos paralelos;

a, c: Parâmetros de rede da célula unitária para o sistema cristalino hexagonal compacto.

\subsubsection{Espectroscopia de Fotoelétrons excitados por Raio-X (XPS)}

A técnica de XPS baseia-se na análise dos fotoelétrons obtidos através da exposição de uma amostra a um feixe de Raio-X mole, ou seja, com energia na faixa de 0,12 a $12 \mathrm{keV}$. Esta janela de energia possibilita a análise dos elétrons de elementos de baixo peso molecular e também dos orbitais mais externos de elementos mais pesados. Com os dados obtidos do número de elétrons contados em determinada energia de excitação, é possível obter informações a respeito do ambiente químico da amostra, estado de oxidação dos elementos, dentre outras.

As análises das amostras de $\mathrm{Ru} / \mathrm{C}$ e de $\mathrm{Ru}_{7} \mathrm{Pd}_{3} / \mathrm{C}$ foram realizadas na linha SXS do Laboratório Nacional de Luz Sincrotron (LNLS). Os espectros foram coletados utilizando-se energia incidente de 1,84 keV obtida através de um monocromador InSb(111). O analisador hemisférico (Specs - phobos 150) foi programado para passagem de $20 \mathrm{eV}$, com passo de 0,2 eV e tempo de aquisição de $200 \mathrm{~ms}$ por ponto. A pressão da câmara de análise foi de 1.3 * $10^{-9} \mathrm{mbar}$. A calibração da energia do fóton do monocromador foi feita na borda $\mathrm{K}$ do silício (1839 eV). Uma calibração adicional da energia do analisador foi feita utilizando-se um 
padrão de folha de ouro, na borda $4 \mathrm{f}$. Todas as análises foram realizadas à temperatura ambiente, com um ângulo de 45 graus em relação ao feixe de incidência.

Para a extração de informações relevantes dos espectros obtidos, utilizou-se o software CasaXPS, no qual foram realizadas simulações matemáticas com 0 ajuste de diversas curvas gaussianas, até que a somatória destas curvas se aproximasse o máximo possível do espectro obtido, de acordo com os valores de energia de ligação disponíveis na literatura. Para a análise do Ru nos catalisadores, utilizou-se a região de energia do orbital $3 p_{3 / 2}(470 \mathrm{a} 450 \mathrm{eV})$.

\subsubsection{Microscopia Eletrônica de Transmissão (TEM)}

Os materiais sintetizados foram também analisados pela técnica de TEM, a fim de se obter o tamanho médio das partículas metálicas, analisar a dispersão dos metais sobre o suporte de carbono e estudar a morfologia do catalisador.

As micrografias foram feitas no LNNano (Laboratório Nacional de Nanotecnologia), situado nas dependências do CNPEM (Centro Nacional de Pesquisa em Energia e Materiais), em Campinas-SP. O equipamento utilizado foi um microscópio 2100 FEG-TEM, com 200 kV de voltagem de aceleração, canhão de elétrons de ZrO/W(100) e detector Gatan com BF e HAADF ("Bright Field" e "High Angle Annular Dark Field"). Com as imagens obtidas utilizando-se o detector BF foi realizada a contagem das partículas, bem como a medida de suas dimensões, a fim de se obter uma distribuição dos tamanhos das partículas metálicas no material. As imagens obtidas com o detector HAADF foram utilizadas meramente para se distinguir a porção metálica dos outros materiais no catalisador, como o suporte de carbono.

Os tamanhos de partículas obtidos por TEM foram comparados com os TMC, obtidos por DRX. A combinação destas duas técnicas possibilita um melhor entendimento da morfologia do material, podendo-se dimensionar os domínios 
cristalinos com o tamanho das partículas e sua dispersão sobre o suporte de carbono.

\subsection{Eletrodos de Difusão Gasosa (EDG)}

Os eletrodos de difusão gasosa (EDG) empregados neste estudo são caracterizados por apresentarem boa condutividade eletrônica e elevada área superficial, permitindo um fluxo gasoso com baixa resistência difusional ${ }^{[61]}$. Para serem utilizados na célula, os EDG foram preparados com camadas difusoras em ambos os lados de um tecido de carbono e uma camada catalítica, em apenas um dos lados. Por convenção, apenas o lado no qual foi depositada somente camada difusora recebeu a denominação de camada de difusão gasosa (CDG). No presente estudo foram empregados eletrodos de $4,62 \mathrm{~cm}^{2}$ de área geométrica.

\subsubsection{Camada de difusão gasosa (CDG)}

A camada de difusão gasosa (CDG) é responsável por manter contato com os canais de difusão de gás e é por onde o gás afluente penetra no eletrodo, difundindo-se para a camada catalítica ${ }^{[62]}$. No presente trabalho as modificações foram realizadas nesta superfície, adicionando-se material catalítico com o intuito de remover o CO antes que este se difunda para a camada catalítica.

Para a preparação desta camada difusora, uma dispersão contendo 85\% de carbono e $15 \%$ de Teflon foi preparada, sabendo-se que cada eletrodo deverá conter 2,55 mg de carbono por centímetro quadrado de área geométrica. Esta dispersão foi então agitada em banho de ultrassom durante 15 minutos, após os quais seu $\mathrm{pH}$ foi ajustado para 3 através da adição gota a gota uma solução de $\mathrm{H}_{2} \mathrm{SO}_{4}$ com concentração de $0,5 \mathrm{molL}^{-1}$. A diminuição do pH promove a desestabilização da dispersão, ocasionando a formação de grandes flocos contendo 
carbono e Teflon $^{\circledR}$, que podem ser filtrados e homogeneamente espalhados sobre o EDG.

Este procedimento foi realizado nos dois lados do tecido de carbono a ser utilizado como EDG do cátodo. No caso do ânodo, numa das faces do tecido o procedimento foi idêntico ao realizado para o cátodo, e na outra face foi empregado o catalisador de Ru a ser estudado. Após o término de todos estes processos, o EDG com as camadas difusoras depositadas foi levado à estufa, primeiramente sob uma temperatura de $280{ }^{\circ} \mathrm{C}$ durante meia hora, de maneira a eliminar os componentes voláteis presentes. Em seguida, a temperatura foi aumentada para $330^{\circ} \mathrm{C}$ por mais meia hora, promovendo a sinterização do Teflon, fixando-se assim a camada difusora no tecido.

Espera-se que com a inserção de Ru e Pd, a CDG também atue como um filtro, promovendo, neste caso, a reação de metanação do CO.

\subsubsection{Camada catalítica}

A camada catalítica é a região na qual ocorrem as reações de oxidação (ânodo) e redução (cátodo). Portanto, deverá manter contato permanente com o eletrólito. Todas as camadas catalíticas deste trabalho foram confeccionadas com a mesma composição utilizando-se a mesma sistemática tanto para o ânodo quanto para o cátodo.

A preparação da camada catalítica consiste na deposição quantitativa de uma tinta contendo pó catalisador e solução de Nafion em álcool isopropílico sobre um lado do EDG, sendo o lado que continha somente carbono, no caso do ânodo. O catalisador utilizado para a preparação da tinta foi Pt/C (ETE-K), contendo 20\% de Pt sobre Carbono em massa. Para um eletrodo de 4,62 $\mathrm{cm}^{2}$, a massa de catalisador utilizada foi 9,2 mg, o que equivale afirmar que cada eletrodo contém 0,4 mg de Pt por $\mathrm{cm}^{2}$. Sobre o catalisador foram adicionados $97 \mu \mathrm{l}$ de solução de Nafion ${ }^{\circledR}$ com concentração de $6 \%$ v/v e gotas de álcool isopropílico, cujo papel é atuar como agente dispersante. Esta suspensão foi colocada sob agitação em ultrassom durante 
15 minutos e então deixada secar, obtendo-se o pó para pintura do eletrodo. A tinta foi reconstituída pela adição de gotas de álcool isopropílico e depositada, com o auxílio de um pincel, sobre uma das faces dos eletrodos. Após a deposição da camada catalítica, o eletrodo foi seco em estufa a $90{ }^{\circ} \mathrm{C}$, durante $1 \mathrm{~h}$ e armazenado até a utilização.

\subsection{Preparação do conjunto Membrana-Eletrodos (MEA)}

O MEA (do inglês "Membrane Electrode Assembly") é o conjunto formado pelo eletrólito, os dois eletrodos e espaçadores, para compensar a altura dos eletrodos em relação à membrana.

Como membrana trocadora de prótons, foi utilizado Nafion ${ }^{\circledR} 115$ (DuPont, 125 $\mu \mathrm{m}$ de espessura) que, para ser utilizada na célula a combustível, passou por um tratamento prévio com a finalidade de ativar os sítios de troca protônica. Este tratamento encontra-se descrito na literatura ${ }^{[63]}$ e consiste basicamente em submergir diversas vezes a membrana em solução de de ácido nítrico e posteriormente em peróxido de hidrogênio, a quente. Após estes pré-tratamentos da membrana, um EDG foi disposto sobre cada uma das faces do eletrólito sólido, mantendo-se as camadas catalíticas em contato com a membrana, para que o transporte protônico entre ânodo e cátodo ocorra com a eficiência desejada. Finalmente, para compensar a espessura dos EDG sobre a membrana, foi utilizado um espaçador de cada lado. Este conjunto foi prensado a quente $\left(130^{\circ} \mathrm{C}, 1000 \mathrm{kgf}\right.$ $\mathrm{cm}^{-2}$ ) durante dois minutos de maneira a unir todos os seus constituintes, e recebe $\mathrm{o}$ nome de MEA (do inglês "Membrane and Electrode Assembly"). 


\subsection{Montagem da célula}

A montagem da célula encontra-se amplamente descrita na literatura ${ }^{[63]}$, sendo, portanto, brevemente descrita.

Inicialmente, o MEA foi disposto entre duas placas de grafite, cada uma com canais de difusão gasosa, por onde o gás percorre e penetra no EDG. Além disso, destas placas também saem fios pelos quais é feito o controle do potencial da célula, pois o grafite é um ótimo condutor eletrônico e, neste caso, encontra-se muito próximo dos eletrodos, diminuindo, portanto, as perdas por queda ôhmica.

Este conjunto de placas de grafite e MEA foi acomodado entre duas placas de alumínio, para facilitar o manuseio da célula e para realizar o controle da corrente elétrica do sistema. Além disso, cartuchos de aquecimento foram inseridos nestas placas, possibilitando o controle da temperatura da célula, com o auxílio de um termopar. Os experimentos foram realizados em duas temperaturas: $85^{\circ} \mathrm{C}$ e $105^{\circ} \mathrm{C}$.

Como a membrana de Nafion deve operar sempre na presença de água, de maneira a garantir o transporte protônico, todo o gás que permeia pelos canais de difusão gasosa deve estar saturado com água. Para satisfazer este propósito utilizaram-se duas garrafas de umidificação: uma para o cátodo e outra para o ânodo, cada uma disposta previamente à respectiva placa de alumínio. As temperaturas das garrafas de umidificação foram ajustadas conforme descrito em trabalhos anteriores ${ }^{[63]}$, sendo a água de umidificação dos gases do ânodo mantida 15 graus e a do cátodo 5 graus acima da temperatura da célula.

A pressão dos gases foi controlada de maneira a se obter uma atmosfera saturada com água. Quando a temperatura da célula foi $85^{\circ} \mathrm{C}$, a garrafa de umidificação anódica estava a $100{ }^{\circ} \mathrm{C}$ e 1 bar e a garrafa de umidificação catódica estava a $90^{\circ} \mathrm{C}$ e 0,7 bar. Quando a temperatura de operação da célula foi $105^{\circ} \mathrm{C}$, a garrafa de umidificação anódica operou a $120^{\circ} \mathrm{C}$ e 2 bar e a garrafa de umidificação catódica operou a $110^{\circ} \mathrm{C}$ e 1,4 bar . 


\subsection{Acoplamento com o espectrômetro de massas}

Na saída dos gases do compartimento anódico da célula foi confeccionada uma interface com um espectrômetro de massas analisador de gases Pfeifer ${ }^{\circledR}$ Omnia Star ${ }^{\mathrm{TM}}$, com analisador quadrupolo. Essa interface é composta de um capilar metálico inserido na placa de grafite, que é conectado ao analisador de gases. Todo o capilar foi mantido aquecido durante as tomadas de medidas, para impedir a condensação de vapores.

Desta maneira, este sistema analisa prontamente o gás efluente anódico, exibindo em tempo real as correntes iônicas dos resíduos de massa a desejados, neste caso, o resíduo de massa 15 , correspondendo à primeira ionização do metano. Com esta configuração, realizaram-se trocas gasosas, alternando-se o gás de alimentação anódica entre hidrogênio puro e hidrogênio contendo: (a) 100 ppm de $\mathrm{CO}$ (b) $75 \mathrm{ppm}$ de $\mathrm{CO}$ (c) $25 \%$ de $\mathrm{CO}_{2}+75 \mathrm{ppm}$ de $\mathrm{CO}$ (d) $25 \%$ de $\mathrm{CO}_{2}$, observando em tempo real as características da reação de metanação, ou seja, em que condições ocorre, se apresenta perfil transiente ou de produção contínua, o efeito do tratamento térmico e o efeito da presença de $\mathrm{CO}_{2}$.

Para quantificar a produção de metano, foram obtidas curvas analíticas utilizando-se um padrão de $50 \mathrm{ppm}$ de $\mathrm{CH}_{4}$ em $\mathrm{H}_{2} \mathrm{e}$, por intermédio de um fluxímetro MKS-Type 247, foram feitas misturas deste padrão em $\mathrm{H}_{2}$ puro, obtendo-se diversas pressões parciais de $\mathrm{CH}_{4}$ sendo o fluxo total igual a $300 \mathrm{ml} \mathrm{min}{ }^{-1}$. Cada curva analítica foi obtida com pelo menos cinco pressões parciais de $\mathrm{CH}_{4}$, correspondendo a concentrações entre 0 ppm e 50 ppm de $\mathrm{CH}_{4}$.

Na Figura 2 encontra-se um exemplo da curva de calibração obtida com o padrão de 50 ppm de metano em hidrogênio, para diversas pressões parciais deste gás.

O ajuste linear nos pontos deste gráfico, de corrente iônica versus concentração, fornece uma equação de reta. A aplicação da equação da reta nas correntes iônicas relativas à razão massa/carga 15, obtidas durante os experimentos 
com o espectrômetro de massas, permitiu se obter diretamente a concentração de metano efluente da câmara anódica.

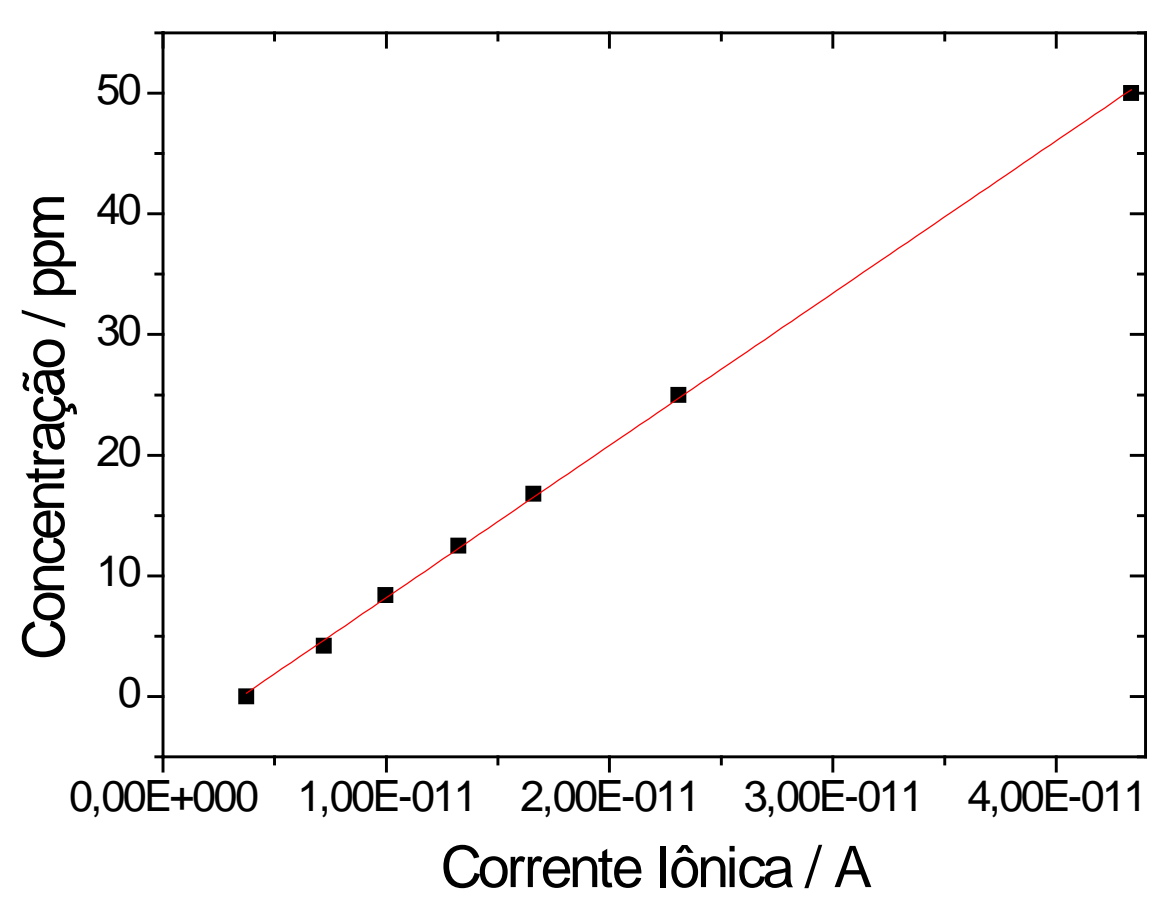

Figura 2: Curva analítica para concentração de metano, utilizando-se espectrômetro de massas na saída do compartimento anódico da célula.

Para que o valor de concentração encontrado seja confiável, os pontos da curva de calibração devem tender à linearidade. Isto é verificado utilizando-se um parâmetro conhecido como coeficiente de correlação r. O valor de r pode ser obtido pela fórmula de Pearson ${ }^{[64]}$ e mostra o quão próximo o conjunto de dados está de representar uma reta. Um coeficiente próximo de 1 indica uma correlação linear crescente, um coeficiente -1 indica uma correlação linear decrescente e um coeficiente próximo de 0 indica que não há correlação linear entre os dados do conjunto. Normalmente um coeficiente $r$ igual a 0,99 indica uma boa correlação linear ${ }^{[64]}$. Nos experimentos realizados neste trabalho, somente curvas de calibração com coeficiente de correlação 0,999 ou superior foram consideradas. 


\subsection{Filtro de linha gasosa}

Para proporcionar um maior controle experimental sobre a reação de metanação foi utilizado também um filtro de linha gasosa, cujo meio filtrante consiste de um cilindro oco de aço poroso, dentro do qual foram acomodados $13 \mathrm{mg}$ do catalisador a ser estudado. Neste dispositivo a temperatura pode ser controlada independentemente da temperatura na célula e o filtro pode operar sem a presença de água. As temperaturas nas quais o filtro foi submetido foram 100, 120, 150 e $200{ }^{\circ} \mathrm{C}$. A sistemática dos testes foi a mesma que para as trocas gasosas realizadas somente com a célula, sendo realizados testes com hidrogênio puro, hidrogênio contendo 100 ppm de CO, hidrogênio contendo 75 ppm de CO, hidrogênio contendo $25 \%$ de $\mathrm{CO}_{2}$ e hidrogênio contendo 75 ppm de $\mathrm{CO}$ e $25 \%$ de $\mathrm{CO}_{2}$, com fluxo de $300 \mathrm{ml} \cdot \mathrm{min}^{-1}$, quantificando-se a produção de $\mathrm{CH}_{4}$ através do monitoramento da corrente iônica cuja relação massa/carga foi de 15, correspondente ao fragmento do metano em sua primeira ionização.

\subsection{Curvas polarização em estado estacionário}

As curvas de polarização foram obtidas numa célula unitária de aproximadamente $5 \mathrm{~cm}^{2}$, com o auxílio de uma Carga dinâmica Electronic Load HP - 6050A. Previamente à obtenção das curvas, a célula foi mantida num potencial de $700 \mathrm{mV}$ (quando da utilização de $\mathrm{H}_{2}$ puro) ou $800 \mathrm{mV}$ (ao se utilizar $\mathrm{H}_{2}$ contendo outros contaminantes) durante $2 \mathrm{~h}$, com a finalidade de se diminuir os efeitos de polarização por ativação durante a obtenção das curvas. As curvas de polarização foram obtidas para diferentes composições de gás do ânodo, sendo sempre comparadas com as obtidas quando hidrogênio puro foi utilizado. Quando somente a metanação do CO foi estudada, hidrogênio contendo 100 ppm deste contaminante foi utilizado nos experimentos. Após observar-se a metanação somente de CO para os diversos materiais presentes em camadas difusoras e avaliar o efeito desta reação nas curvas de polarização e desempenho da célula, foram também obtidas 
curvas de polarização com hidrogênio contendo $25 \%$ de $\mathrm{CO}_{2}$ e também hidrogênio contendo $25 \%$ de $\mathrm{CO}_{2}$ e 75 ppm de $\mathrm{CO}$, similarmente ao hidrogênio gerado por reforma catalítica e depois purificado por Oxidação Preferencial (PrOx) ${ }^{[65]}$.

Como a concentração de $\mathrm{CO}_{2}$ foi elevada, houve, portanto, diluição dos outros gases da mistura. Para fins comparativos, curvas de polarização para hidrogênio diluído em 25\% de Argônio e também hidrogênio contendo 75 ppm de $\mathrm{CO}$ foram obtidas. Desta maneira foi avaliado o efeito da presença de $\mathrm{CO}_{2}$ na reação de metanação, fazendo-se correlação entre os perfis obtidos por espectrometria de massas online e o desempenho da célula.

Todos estes experimentos de polarização em estado estacionário foram realizados a $85^{\circ} \mathrm{C}$ e a $105^{\circ} \mathrm{C}$, conforme descrito previamente na seção 3.9 , e realizados com camadas difusoras convencionais e também com as contendo os materiais de interesse para metanação.

Com os dados de polarização em estado estacionário para as diversas composições do gás anódico, foi possível obter o sobrepotencial anódico, $\eta$, como definido na equação 5:

$$
\eta=E_{H_{2}}-E_{H_{2} / \text { contaminantes }}
$$

Onde $\eta=$ sobrepotencial anódico, $E_{H 2}$ o potencial da célula com hidrogênio puro e $E_{H 2 / c o n t a m i n a n t e s ~} 0$ potencial da célula quando o $\mathrm{H}_{2}$ continha outros gases, como o $\mathrm{CO}$.

Desta maneira, o sobrepotencial anódico é uma medida quantitativa da diminuição do desempenho da célula a combustível quando o hidrogênio utilizado no ânodo não é puro e, com as medidas de sobrepotencial para as diversas composições gasosas, foi possível comparar o efeito que cada contaminante ou condição experimental proporciona nas reações da célula. 


\section{RESULTADOS E DISCUSSÃO}

\subsection{Caracterização Física}

\subsubsection{EDX}

$\mathrm{Na}$ Tabela 2 encontram-se os dados obtidos pela técnica de EDX. Estes resultados mostram que a composição dos catalisadores situou-se próxima da composição teórica, ou seja, 40\% em massa de metal depositado sobre carbono. Os desvios padrão podem ser explicados pelo fato de que o valor obtido é uma média de composições de cinco regiões da amostra e que, portanto, podem variar de acordo com a homogeneidade do material analisado, ou seja, da quantidade de metal ancorada nas partículas de carbono em cada região. No presente estudo, as diferenças entre os desvios padrão sugerem que as amostras apresentaram excelentes graus de homogeneidade.

Já para os valores de proporção atômica entre $\mathrm{Pd}$ e Ru, pode-se observar também uma grande correspondência entre o valor teórico e o obtido via EDX, o que indica que todo metal utilizado na síntese foi incorporado ao catalisador.

Tabela 2: Dados obtidos via EDX representando a proporção mássica entre os metais e o suporte de Carbono e proporção atômica entre os metais dos catalisadores em estudo. t.t. indica que o material foi tratado termicamente e depois analisado via EDX.

\begin{tabular}{lll}
\hline Material & M/C $(\mathrm{m} / \mathrm{m} \%)$ & Ru (\% atômica) \\
\hline $\mathrm{Ru} / \mathrm{C}$ & $(49,5 \pm 0,1)$ & $\mathrm{N} / \mathrm{A}$ \\
$\mathrm{Ru} / \mathrm{C}$ t.t. & $(47 \pm 1)$ & $\mathrm{N} / \mathrm{A}$ \\
$\mathrm{Ru}_{7} \mathrm{Pd}_{3}$ & $(44 \pm 2)$ & $(70 \% \pm 1)$ \\
$\mathrm{Ru}_{7} \mathrm{Pd}_{3}$ t. t. & $(44 \pm 1)$ & $(70,0 \pm 0,2)$ \\
$\mathrm{RuPd}$ & $(44 \pm 2)$ & $(51 \pm 0,8)$ \\
\hline
\end{tabular}




\subsubsection{DRX}

Na Figura 3 estão dispostos os difratogramas de RaioX obtidos para os diversos materiais em estudo, antes e após o tratamento térmico. Pode-se observar que no caso dos materiais contendo somente $\mathrm{Ru}$, houve um aumento na proporção de Ru metálico após o tratamento térmico, notado pela maior definição dos picos de difração referentes aos planos cristalográficos do Ru metálico, indicados em azul na Figura 3 e listados na Tabela 3.

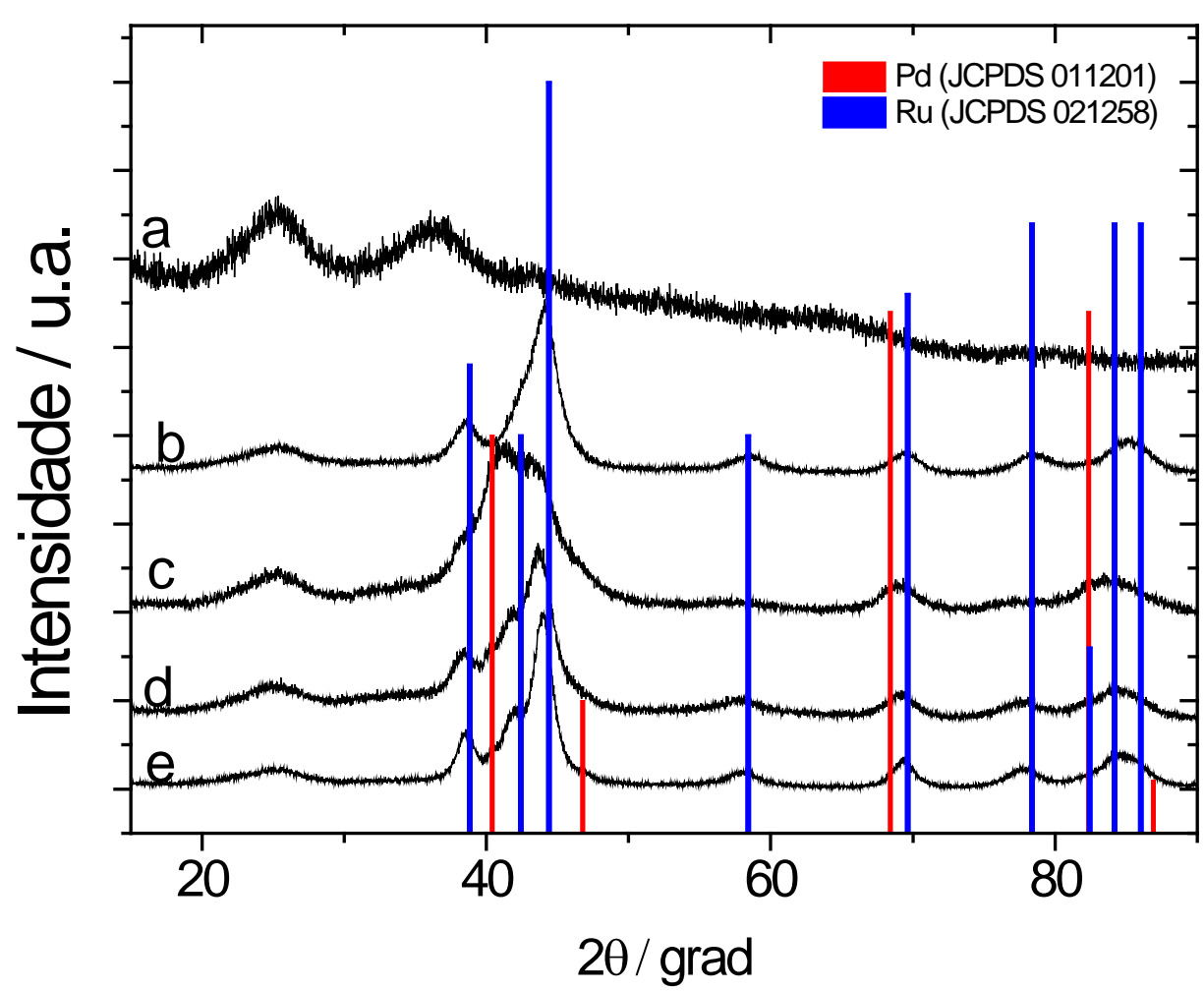

Figura 3: Difratogramas de Raio-X obtidos para os materiais: (a) Ru/C (b) Ru/C após tratamento térmico (c) $\mathrm{Ru}_{7} \mathrm{Pd}_{3} / \mathrm{C}$ (d) $\mathrm{Ru}_{7} \mathrm{Pd}_{3} / \mathrm{C}$ após tratamento térmico e (e) $\mathrm{RuPd} / \mathrm{C}$ 
Tabela 3: Planos cristalográficos e seus respectivos ângulos e intensidade de difração para o Ru, de acordo com dados obtidos o JCPDS ("Joint Committee for Powder Diffraction Structure"), ficha número 021258.

\begin{tabular}{lll}
\hline Plano & $2 \boldsymbol{\theta}$ & $\mathbf{I} / \mathbf{I}_{0}$ \\
\hline$(100)$ & 38,6 & 0,4 \\
$(002)$ & 42,4 & 0,3 \\
$(101)$ & 44,4 & 1 \\
$(102)$ & 58,8 & 0,25 \\
$(110)$ & 69,6 & 0,25 \\
$(103)$ & 79,1 & 0,3 \\
$(200)$ & 82,3 & 0,04 \\
$(102)$ & 85,0 & 0,3 \\
\hline
\end{tabular}

Para os materiais que contém Pd, é possível observar com boa definição os picos de difração antes mesmo de se efetuar o tratamento térmico. No caso do $\mathrm{Ru}_{7} \mathrm{Pd}_{3} / \mathrm{C}$, além dos picos de difração correspondentes ao Ru metálico, é possível observar também um pico de difração ao redor de 40 graus, correspondente à difração na face (111) do $\mathrm{Pd}$, o que indica que, neste caso, houve a presença de fase segregada de Pd. Porém, após o tratamento térmico, não se observou mais a presença deste pico, o que nos leva a inferir que o tratamento promoveu formação de liga entre os dois elementos, com a incorporação do Pd na estrutura do Ru.

Na Tabela 4 estão os parâmetros de rede a e c calculados para os diversos materiais e também os TMC, obtidos com o auxílio da equação de Debye-Scherrer:

Tabela 4: Parâmetros de rede a e c do Ru HCP e tamanho médio de cristalito para os diversos materiais. Os parâmetros a e c também estão comparados com o padrão de Ru.

\begin{tabular}{llll}
\hline Material & $\mathbf{a}(\AA)$ & $\mathbf{c}(\AA)$ & TMC (nm) \\
\hline $\mathrm{Ru} / \mathrm{C}$ t.t. & 2,71 & 4,28 & 2,3 \\
$\mathrm{Ru}_{7} \mathrm{Pd}_{3} / \mathrm{C}$ & 2,72 & 4,37 & 2,6 \\
$\mathrm{Ru}_{7} \mathrm{Pd}_{3} / \mathrm{C}$ t.t. & 2,72 & 4,36 & 2,7 \\
$\mathrm{RuPd} / \mathrm{C}$ & 2,71 & 4,32 & 2,5 \\
$\mathrm{Ru}(\mathrm{JCPDS}$ 021258) & 2,7058 & 4,2819 & \\
\hline
\end{tabular}


Não foi possível realizar os cálculos de TMC e dos parâmetros de rede para o material de Ru/C antes do tratamento térmico devido à ausência de picos no difratograma, o que pode indicar que as partículas formadas continham poucos domínios cristalinos, ou seja, um material com baixo índice de cristalinidade.

Os TMC obtidos foram todos semelhantes entre si, com valores próximos de 2,5 nm, mesmo após o tratamento térmico. Isto demonstra a eficiência da síntese de Ru/C em meio básico contendo formiato de sódio, em atmosfera de hidrogênio. Esta configuração provavelmente promove a pronta redução do Ru assim que uma gota da solução de $\mathrm{RuCl}_{3}$ é adicionada ao sistema, além de agir impedindo a formação de aglomerados devido à elevada força iônica do meio, o que pode ter contribuído para os reduzidos tamanhos de cristalito.

Os parâmetros de rede obtidos para o material de Ru/C se encontram muito próximos daqueles presentes na literatura, apresentando concordância com a estrutura cristalina HCP do rutênio. Quando Pd foi adicionado ao material, não houve alteração no parâmetro a. Porém, notou-se que o parâmetro c aumentou seu valor, em todos os casos. Portanto, especula-se que o Pd adicionado acomodou-se entre os planos principais do sistema cristalográfico do $\mathrm{Ru}$, alongando a célula unitária na direção [001], o que se refletiu num aumento do valor de c.

\subsubsection{XPS}

Na Figura 4 estão os espectros de XPS obtidos para amostras de Ru/C, nos quais é exibida a região de energia de ligação referente ao orbital $3 p_{3 / 2}$ do $R u$. Escolheu-se esta região ao invés da dos orbitais $5 d$, comumente encontrada na literatura, pois o suporte catalítico utilizado neste trabalho foi de carbono. Sendo assim, ocorre a sobreposição dos sinais relativos aos orbitais $5 \mathrm{~d}$ do $\mathrm{Ru}$ com os relativos ao orbital 1 do $\mathrm{C}$, dificultando e até mesmo impossibilitando a resolução dos picos e sua consequente simulação computacional.

A Figura 4a corresponde ao Ru/C sem tratamento térmico, enquanto a Figura 4b corresponde ao mesmo material depois de realizado o tratamento térmico. 
Observando-se estes espectros pode-se chegar à conclusão de que após o tratamento térmico há uma menor quantidade de estados de oxidação para o Ru. Além disso, a proporção relativa de espécies com energia de ligação $461.3 \mathrm{eV}$ (atribuída ao Ru metálico ${ }^{[66]}$ ) aumentou após o tratamento, o que leva a conclusão de que este tratamento térmico atuou como um redutor do Ru presente no catalisador.

O pico situado entre 463.2 e 463.5 eV é atribuído ao Ru (IV) ${ }^{[66]}$, espécie mais estável deste elemento. Em relação ao pico situado próximo de $465 \mathrm{eV}$, há evidências de que seja devido ao Ru (V). Já em relação ao pico ao redor de $467 \mathrm{eV}$, que foi suprimido após o tratamento térmico, não foi encontrado consenso na literatura a respeito do estado de oxidação responsável pelo seu aparecimento. Especula-se que este seja devido ao $\mathrm{Ru}(\mathrm{VII})^{[67]}$. Porém, há artigos que relacionam estes dois picos à presença de espécies oxigenadas de $\mathrm{Ru}$, como $\mathrm{RuO}_{x} \mathrm{H}_{\mathrm{y}}$ ou como $\mathrm{Ru}$ contendo $\mathrm{H}_{2} \mathrm{O}$ adsorvida fortemente em sua superfície ${ }^{[6,68-70]}$.

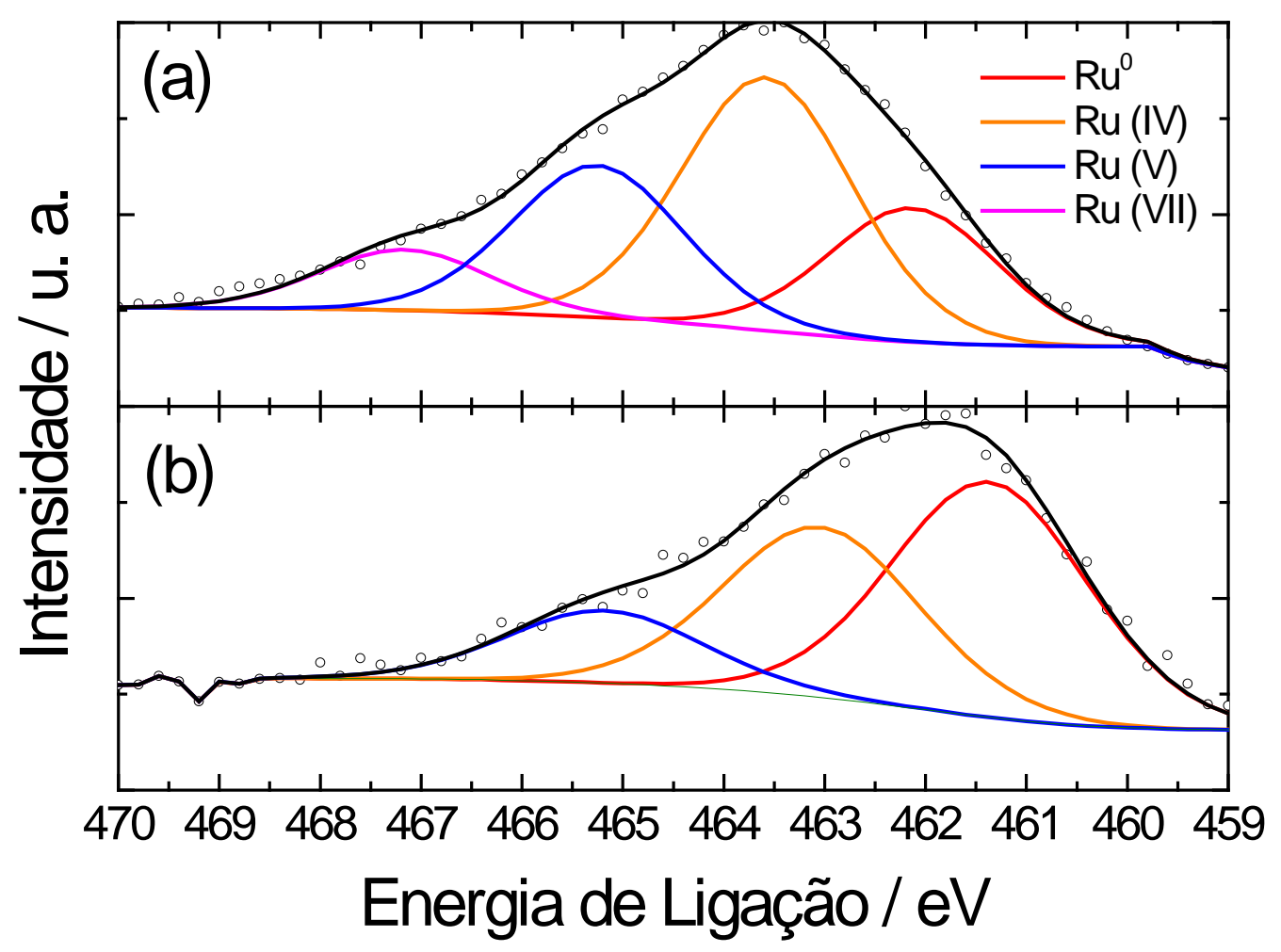

Figura 4: Espectro de XPS para catalisador de Ru/C (a) como preparado, (b) após tratamento térmico. A região de energia corresponde ao orbital $3 p_{3 / 2}$ do $\mathrm{Ru}$ 
Na Figura 5 encontram-se os espectros obtidos por XPS para a região do orbital $3 \mathrm{p}_{3 / 2}$ do $\mathrm{Ru}$ no catalisador $\mathrm{Ru}_{7} \mathrm{Pd}_{3} / \mathrm{C}$. A Figura 5 a contém o espectro para 0 catalisador como preparado e na Figura 5b está o espectro obtido após a realização do tratamento térmico. São notadas as mesmas espécies de Ru que as observadas no catalisador Ru/C recém preparado, com predominância para a espécie de $\mathrm{RuO}_{2}$ (Ru (IV)), com pico em 463.2 eV $^{[66]}$. Outros picos em maiores estados de oxidação também são observados. Porém, como discutido anteriormente, não há consenso na literatura a respeito da atribuição das espécies responsáveis por este sinal ${ }^{[67]}$.

Entretanto, contrariamente ao que o tratamento térmico promoveu no catalisador de Ru/C, não houve alteração apreciável na população e nem no tipo das espécies de $\mathrm{Ru}$ presentes no catalisador de $\mathrm{Ru}_{7} \mathrm{Pd}_{3} / \mathrm{C}$.

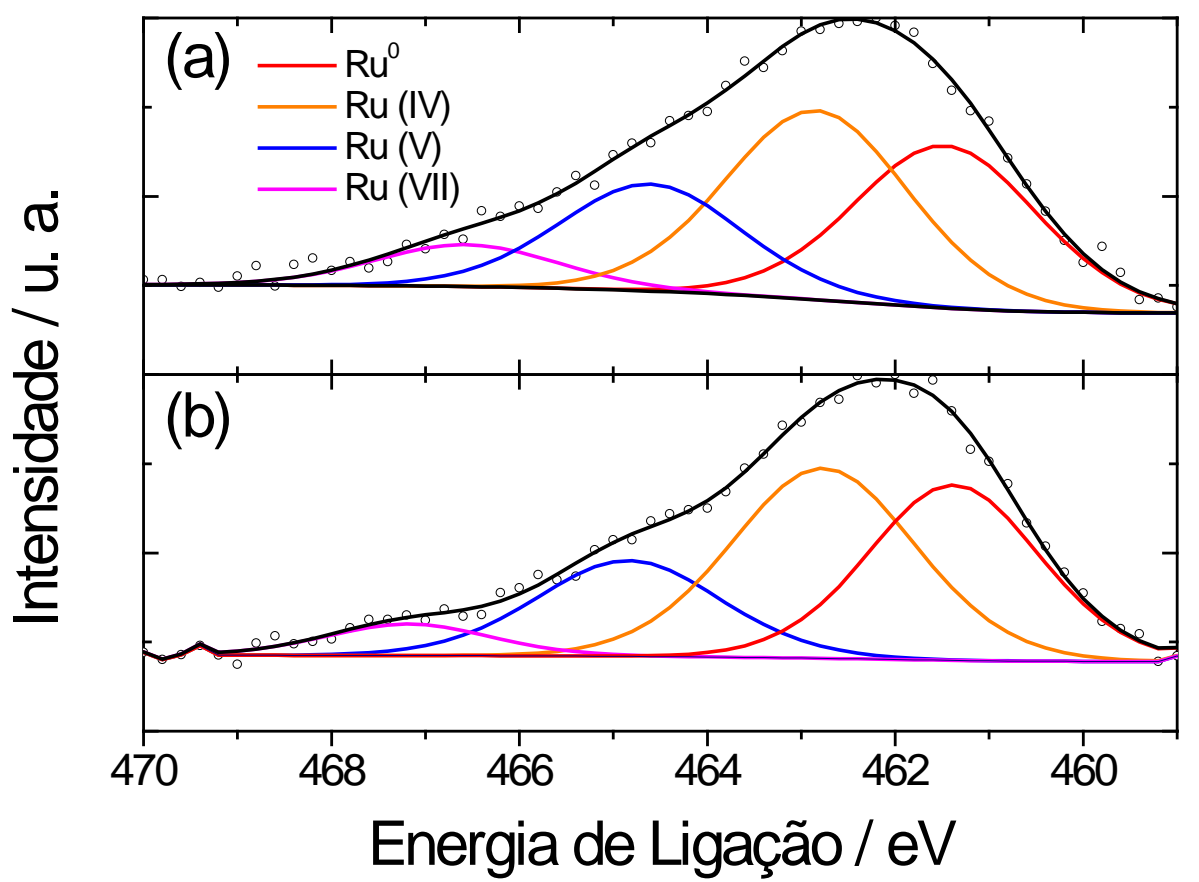

Figura 5: Espectro de XPS para catalisador de $\mathrm{Ru}_{7} \mathrm{Pd}_{3} / \mathrm{C}$ (a) como preparado, (b) após tratamento térmico. A região de energia corresponde ao orbital $3 p_{3 / 2}$ do $\mathrm{Ru}$ 


\subsubsection{TEM}

$\mathrm{Na}$ Figura 6 encontram-se as micrografias dos diferentes materiais sintetizados. Na esquerda da figura estão as imagens de BF ("Bright Field") e na direita estão as imagens de HAADF ("High Angle Annular Dark Field").

Todos os materiais apresentaram uma boa dispersão das partículas metálicas, com exceção do material de Ru/C. Neste, pode-se observar aglomeração de partículas em determinadas regiões. Porém, após o tratamento térmico, não é possível observar a presença das partículas metálicas. Estas são visíveis somente na imagem obtidas por HAADF, onde se pode notar que aparentemente houve um recobrimento do suporte por $\mathrm{Ru}$. 

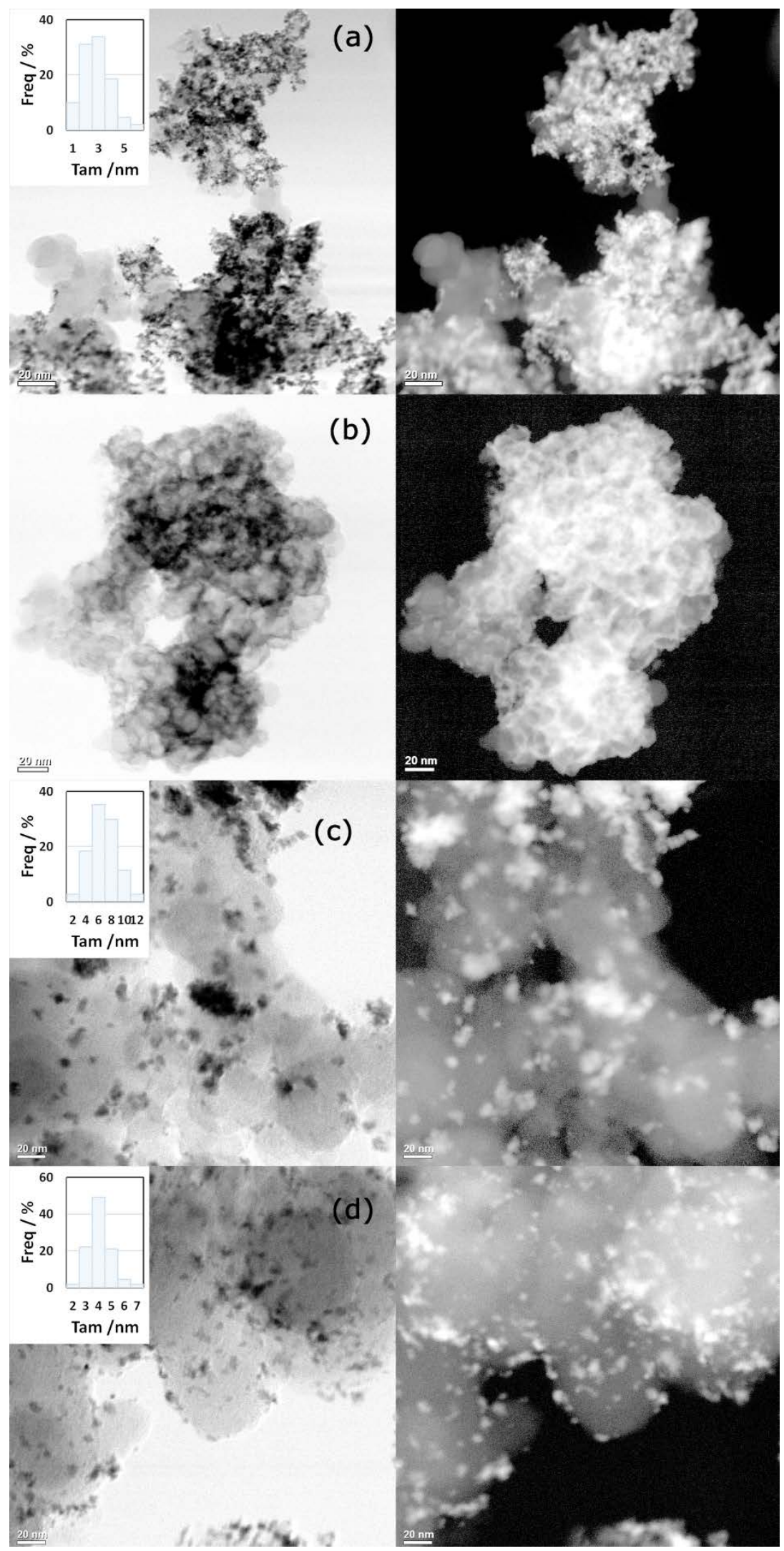

Figura 6: Imagens obtidas por TEM para os materiais: (a)Ru/C, (b) Ru/C após tratamento térmico, (c) $\mathrm{Ru}_{7} \mathrm{Pd}_{3} / \mathrm{C}$ e (d) RuPd/C. Na esquerda estão as imagens obtidas com o detector BF ("Bright Field"); $\mathrm{Na}$ direita estão as imagens obtidas com o detector HAADF ("High-Angle Annular Dark Field"). 
Para os materiais de $\mathrm{Ru}_{7} \mathrm{Pd}_{3} / \mathrm{C}$ e RuPd/C, os tamanhos de partículas obtidos por TEM foram, respectivamente, 5,8 e 3,6 nm. Já os TMC obtidos via DRX para os mesmos materiais, foram 2,6 e 2,5 nm. Estas informações nos permitem concluir que nestes materiais, a partícula catalítica consiste de um domínio formado por um aglomerado de nanocristais responsáveis pelos picos nos gráficos de DRX e pela atividade catalítica do material.

4.2. Camada difusora modificada com $\mathrm{Ru} / \mathrm{C}, \mathrm{Ru}_{7} \mathrm{Pd}_{3} / \mathrm{C}$ e $\mathrm{RuPd} / \mathrm{C}$

\subsubsection{Reação de metanação}

\subsubsection{Efeito da adição de $\mathrm{Pd}$ em Ru/C}

Na Figura 7 encontra-se o perfil de produção de metano (evolução da taxa de produção de metano) obtido quando a célula foi mantida em circuito aberto a $85^{\circ} \mathrm{C}$ e somente Ru/C (sem tratamento térmico) foi utilizado na CDG. Com esta configuração, a célula foi alimentada intermitentemente por $\mathrm{H}_{2}$ e $\mathrm{H}_{2}$ contendo 100 ppm de CO. O perfil observado é muito semelhante ao descrito por Lopes et $a l^{[42]}$, no qual verifica-se uma maior produção de $\mathrm{CH}_{4}$ quando reveza-se o gás de alimentação de $\mathrm{H}_{2}$ contendo $\mathrm{CO}$ para $\mathrm{H}_{2}$ puro. 


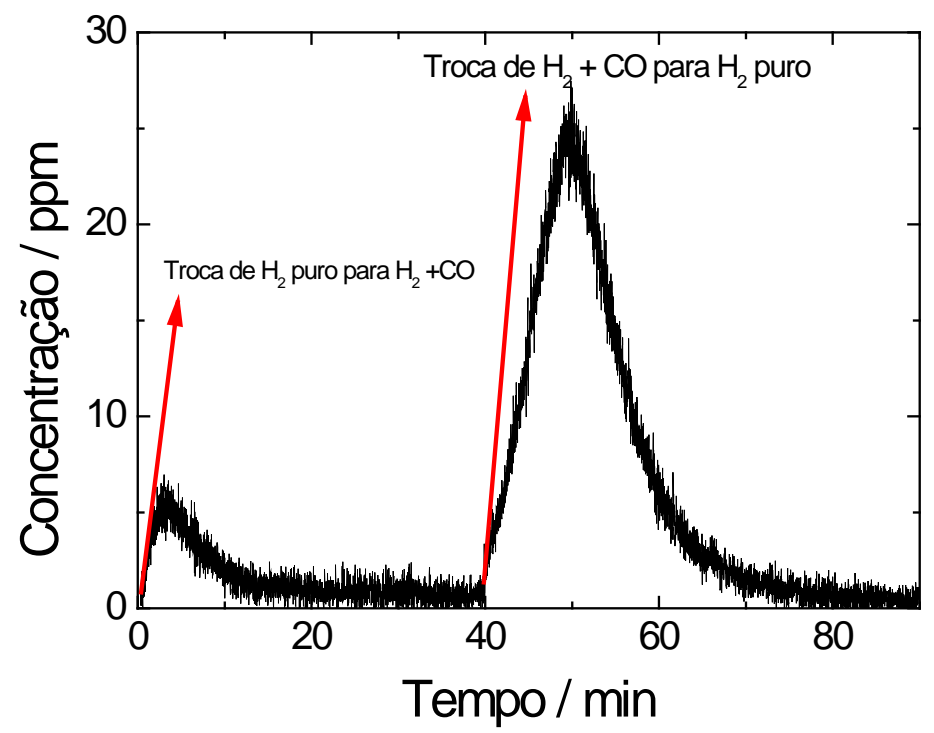

Figura 7: Produção de $\mathrm{CH}_{4}$ durante o revezamento do gás de alimentação anódica de $\mathrm{H}_{2}$ puro para $\mathrm{H}_{2}$ contendo $100 \mathrm{ppm}$ de $\mathrm{CO}$ e de $\mathrm{H} 2$ contendo $100 \mathrm{ppm}$ de $\mathrm{CO}$ para $\mathrm{H} 2$ puro, quando catalisador $\mathrm{Ru} / \mathrm{C}$ foi utilizado na camada difusora anódica, $\mathrm{a} 85^{\circ} \mathrm{C}$

$\mathrm{O}$ caráter transiente da produção de $\mathrm{CH}_{4}$ evidencia que esta reação ocorre somente com espécies adsorvidas na superfície do $\mathrm{Ru}^{[42]}$. Dada a forte interação do Ru com CO, sempre que este estiver presente no fluxo gasoso a superfície será rapidamente recoberta, restando poucos sítios para a adsorção e dissociação de $\mathrm{H}_{2}$, necessários para que ocorra a redução do CO superficial, como demonstrado na reação 8.

$$
\mathrm{CO}_{a d s}+6 \mathrm{H}_{a d s} \leftrightharpoons \mathrm{CH}_{4}+\mathrm{H}_{2} \mathrm{O}
$$

Reação 8: Metanação do CO

$\mathrm{Na}$ situação em que, inicialmente $\mathrm{H}_{2}$ contendo $\mathrm{CO}$ flui através da camada difusora do ânodo, a maior parte da superfície encontra-se bloqueada por $\mathrm{CO}$, sendo, portanto, a quantidade de $\mathrm{H}_{\text {ads }}$ o limitante da reação. Ao se trocar o gás de alimentação para hidrogênio puro, livre de $\mathrm{CO}$, a metanação ocorre e sítios reacionais são liberados, possibilitando a adsorção dissociativa de $\mathrm{H}_{2}$. Esta limpeza da superfície com subsequente aumento do recobrimento por hidrogênio é 
observada pelo aumento na taxa de produção de metano, num mecanismo auto catalítico em que a taxa de metanação aumenta proporcionalmente à quantidade de hidrogênio superficial disponível para reagir. Este efeito prossegue até uma taxa reacional máxima, na qual a quantidade de $\mathrm{CO}_{\text {ads }}$ passa a ser o limitante da reação, dada sua escassez na superfície. Neste momento, conforme a metanação ocorre há uma redução na concentração de $\mathrm{CO}_{\mathrm{ads}}$, o que reflete numa menor taxa de reação, e assim a reação se auto desativa, até a remoção completa do CO da superfície.

Mecanismo similar ocorre quando da troca de $\mathrm{H}_{2}$ puro para $\mathrm{H}_{2}$ contendo 100 ppm de CO. Porém, a área sobre este pico de produção é da ordem de seis vezes menor do que a área sobre o pico de produção da troca de $\mathrm{H}_{2} / \mathrm{CO}$ para $\mathrm{H}_{2}$ puro. Isto ocorre devido à diferença nas espécies que recobrem a superfície em cada situação. Quando a atmosfera que envolve o catalisador é de $\mathrm{H}_{2}$ contendo $\mathrm{CO}$, pode-se considerar que praticamente toda a superfície está recoberta por CO, como explanado acima. Portanto, cada espécie adsorvida produzirá uma molécula de metano ao remover-se o CO da composição da atmosfera. Entretanto, quando o catalisador está sob atmosfera somente de hidrogênio, está é a única espécie que recobre a superfície. Como a reação de metanação envolve seis hidrogênios elementares adsorvidos para cada molécula de metano formada (Reação 8), a cada seis moléculas adsorvidas será formada uma molécula de metano, ao se introduzir $\mathrm{CO}$ no fluxo de $\mathrm{H}_{2}$. Portanto, a quantidade de $\mathrm{CH}_{4}$ produzida na troca de hidrogênio puro para hidrogênio contendo $\mathrm{CO}$ é seis vezes menor do que na troca de hidrogênio contendo CO para hidrogênio puro. ${ }^{[42]}$.

Quando Pd foi adicionado ao catalisador nenhuma melhora foi observada tanto do ponto de vista de maior evolução de metano quanto da obtenção de um perfil de produção estacionária deste gás, que poderia promover uma limpeza contínua da superfície. Muito pelo contrário, o que se observa é um pico menor e com período mais prolongado, como pode ser visualizado na Figura 8, o que indica que a reação foi desfavorecida pela adição de $\mathrm{Pd}$ ao $\mathrm{Ru} / \mathrm{C}$. Além do mais, os transientes da Figura 8 são relacionados à troca de $\mathrm{H}_{2} / \mathrm{CO}$ para $\mathrm{H}_{2}$ puro, pois para estes catalisadores contendo $\mathrm{Pd}$ a quantidade de $\mathrm{CH}_{4}$ produzida na mudança de $\mathrm{H}_{2}$ puro para $\mathrm{H}_{2} / \mathrm{CO}$ situa-se abaixo do limite de detecção do sistema. 
O gráfico de produção de $\mathrm{CH}_{4}$ em $\mathrm{Ru}_{5} \mathrm{Pd}_{5} / \mathrm{C}$ foi omitido pelo fato da produção de metano também encontrar-se abaixo do limite de detecção do aparelho, neste caso também para a troca de $\mathrm{H}_{2} / \mathrm{CO}$ para $\mathrm{H}_{2}$ puro. Estes resultados indicam que $\mathrm{O}$ aumento da concentração de $\mathrm{Pd}$ nas ligas com $\mathrm{Ru}$ promove uma diminuição da cinética da reação de metanação.

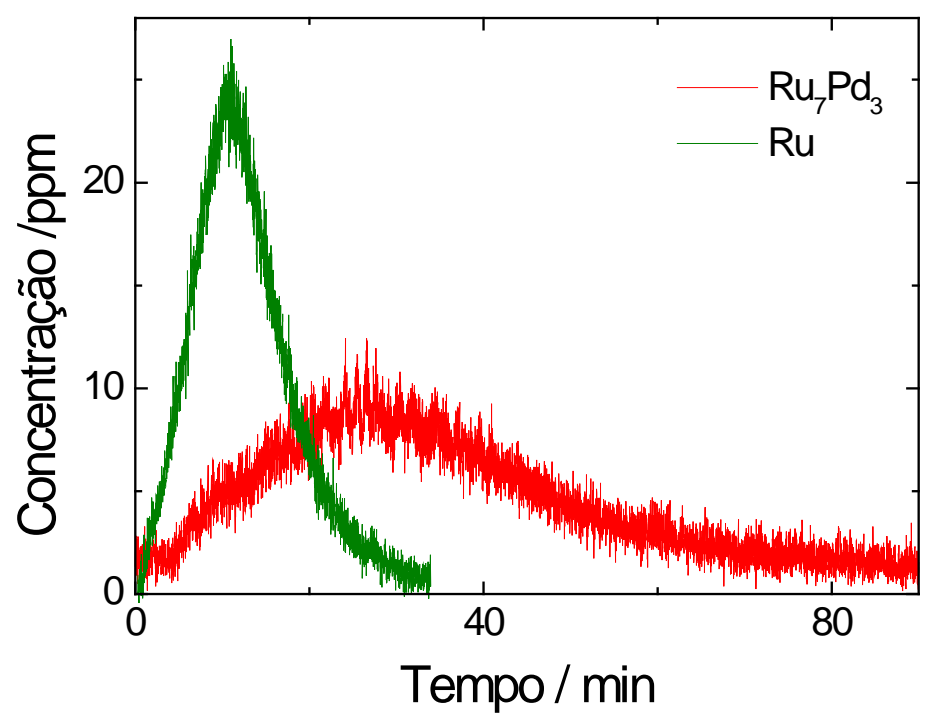

Figura 8: Perfis de produção de $\mathrm{CH}_{4}$ quando troca-se o gás de alimentação anódica de $\mathrm{H}_{2}+100 p p m$ de $\mathrm{CO}$ para $\mathrm{H}_{2}$ puro, utilizando-se $\mathrm{Ru} / \mathrm{C}$ ou $\mathrm{Ru}_{7} \mathrm{Pd}_{3} / \mathrm{C}$ como catalisador na camada difusora anódica.

A área sob a curva de produção de metano para o $\mathrm{Ru}_{7} \mathrm{Pd}_{3} / \mathrm{C}$ permanece essencialmente a mesma que para o Ru/C, indicando que não houve diferença entre o grau de recobrimento para os dois materiais, ou seja, na afinidade do CO pela superfície. A presença de Pd parece então ter reduzido a velocidade da etapa determinante da reação, desfavorecendo o estado de transição. Como o Pd é conhecidamente hidrogenofílico, especula-se, portanto, que nas condições experimentais observadas, a reação de hidrogenação da superfície (Reação 9) não é a etapa determinante de velocidade para a reação.

$$
2 \mathrm{RuPd}+\mathrm{H}_{2} \leftrightharpoons 2 \mathrm{RuPd}-\mathrm{H}
$$


Esta evidência a respeito da etapa determinante de velocidade é corroborada por Schouten et. al ${ }^{[71]}$, que propõem um mecanismo para a redução do $\mathrm{CO}_{2}$ à diversos compostos, entre eles o $\mathrm{CH}_{4}$. No mecanismo de conversão do $\mathrm{CO}_{2}$ à $\mathrm{CH}_{4}$, $\mathrm{CO}_{2}$ é adsorvido na superfície do catalisador e dissocia-se produzindo uma espécie oxigenada e $\mathrm{CO}$ superficial. Os autores também propõem que a etapa determinante para a transformação de $\mathrm{CO}$ em $\mathrm{CH}_{4}$ é a quebra da ligação $\mathrm{CO}$, formando água e uma espécie de $\mathrm{CH}_{2}$ adsorvida, como mostrado na Reação 10:

$$
4 \mathrm{Ru}-\mathrm{H}+\mathrm{Ru}-\mathrm{CO} \leftrightharpoons \mathrm{Ru}-\mathrm{CH}_{2}+\mathrm{H}_{2} \mathrm{O}+4 \mathrm{Ru}
$$

Reação 10: Proposta de etapa determinante de velocidade para a redução do $\mathrm{CO}$, via quebra de ligação CO.

Panagiotopoulou e sua equipe ${ }^{[72]}$ realizaram experimentos para elucidar o mecanismo de metanação do $\mathrm{CO}$ e a seletividade desta reação na presença de $\mathrm{CO}_{2}$, utilizando catalisador de $\mathrm{Ru} / \mathrm{TiO}_{2}$. Os autores propõem que existem dois mecanismos para a metanação do CO:

$\rightarrow$ Adsorção dissociativa, gerando espécies oxigenadas superficiais e consequente hidrogenação da espécie de carbono formada. Esta reação ocorreria somente em temperaturas inferiores a $250{ }^{\circ} \mathrm{C}$, sendo as espécies oxigenadas produzidas durante a adsorção dissociativa as responsáveis pela inativação do catalisador para a metanação, após certo tempo, como ilustrado nas Reações 11 e 12:

$$
\begin{aligned}
2 R u+C O & \leftrightharpoons R u \sim C+R u O \\
4 R u-H+R u \sim C+R u O & \leftrightharpoons R u \sim C H_{2}+R u-H_{2} O+4 R u
\end{aligned}
$$

$\rightarrow$ Hidrogenação direta de espécies carboniladas, geradas pela adsorção não dissociativa do CO. Neste caso, ocorre somente em temperaturas superiores a 250 ${ }^{\circ} \mathrm{C}$ e é o caminho preferencial para a metanação do $\mathrm{CO}_{2}$, após este ter se dissociado para formação do intermediário carbonilado, como demonstrado nas Reações 13 e 14: 


$$
\begin{aligned}
\mathrm{CO}+2 \mathrm{Ru} & \leftrightharpoons \mathrm{RuCORu} \\
\mathrm{RuCORu}+6 \mathrm{Ru}-\mathrm{H} & \leftrightharpoons \mathrm{CH}_{4}+\mathrm{H}_{2} \mathrm{O}+8 \mathrm{Ru}
\end{aligned}
$$

\subsubsection{Efeito do aumento da temperatura}

Após a identificação do efeito nulo ou negativo da adição de Pd no material de Ru/C para a metanação, novos testes foram realizados utilizando-se este material, com o intuito de tornar a produção de $\mathrm{CH}_{4}$ contínua quando da presença de $\mathrm{H}_{2}$ contendo 100 ppm de CO. A Figura 9 mostra o resultado obtido ao se aumentar em $20{ }^{\circ} \mathrm{C}$ a temperatura de operação da célula.

Pode-se inferir que neste caso houve produção contínua de $\mathrm{CH}_{4}$, à qual ocorre devido ao menor recobrimento superficial pelo $\mathrm{CO}$, comparativamente a $85^{\circ} \mathrm{C}^{[73]}$, e também pela remoção mais eficiente das espécies oxigenadas formadas pela adsorção dissociativa do $\mathrm{CO}^{[72]}$. Portanto, menos sítios de $\mathrm{Ru}$ estarão bloqueados, podendo o hidrogênio adsorver-se dissociativamente em paralelo à adsorção do CO dando prosseguimento à reação de metanação.

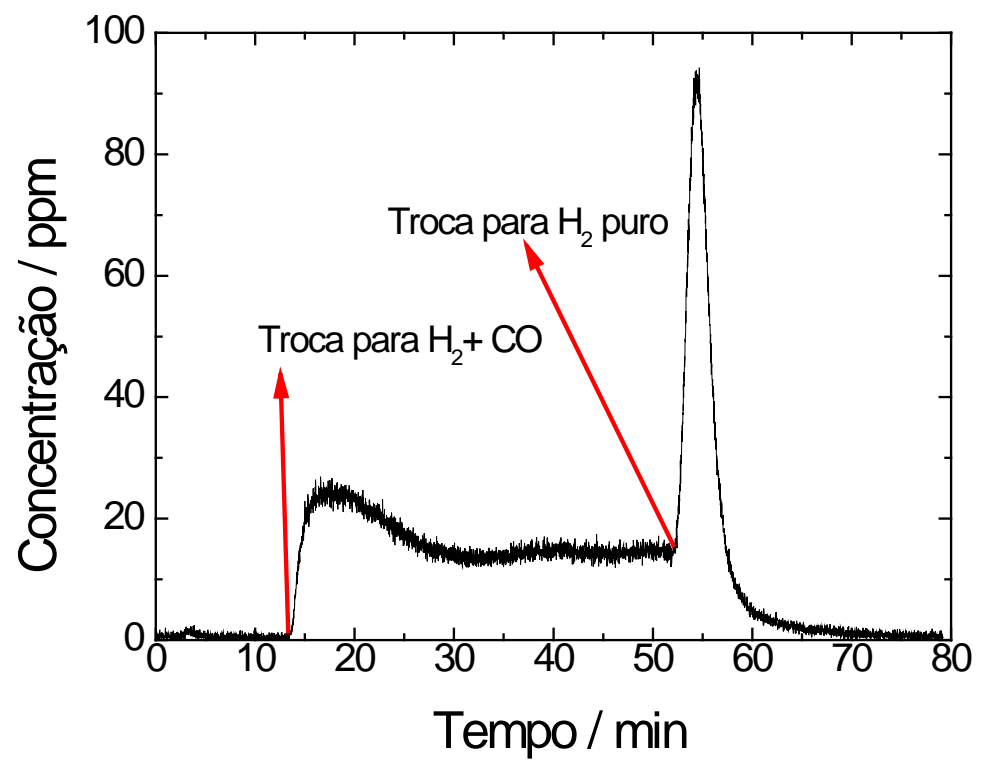

Figura 9: Perfil de produção de $\mathrm{CH}_{4}$ a $105^{\circ} \mathrm{C}$ em catalisador Ru/C sem tratamento térmico, quando utilizado em CDG. 


\subsubsection{Efeito do tratamento térmico em Ru/C}

O material de Ru/C também foi tratado termicamente, em atmosfera de hidrogênio saturado com água, conforme descrito na parte experimental (seção 3.2). Após este tratamento térmico, foram confeccionadas CDG utilizando-se este catalisador tratado ao invés de se utilizar somente $C$, como feito no método convencional. Na Figura 10 encontra-se o perfil de produção de metano, a $85{ }^{\circ} \mathrm{C}$, para camada difusora contendo este material tratado termicamente.

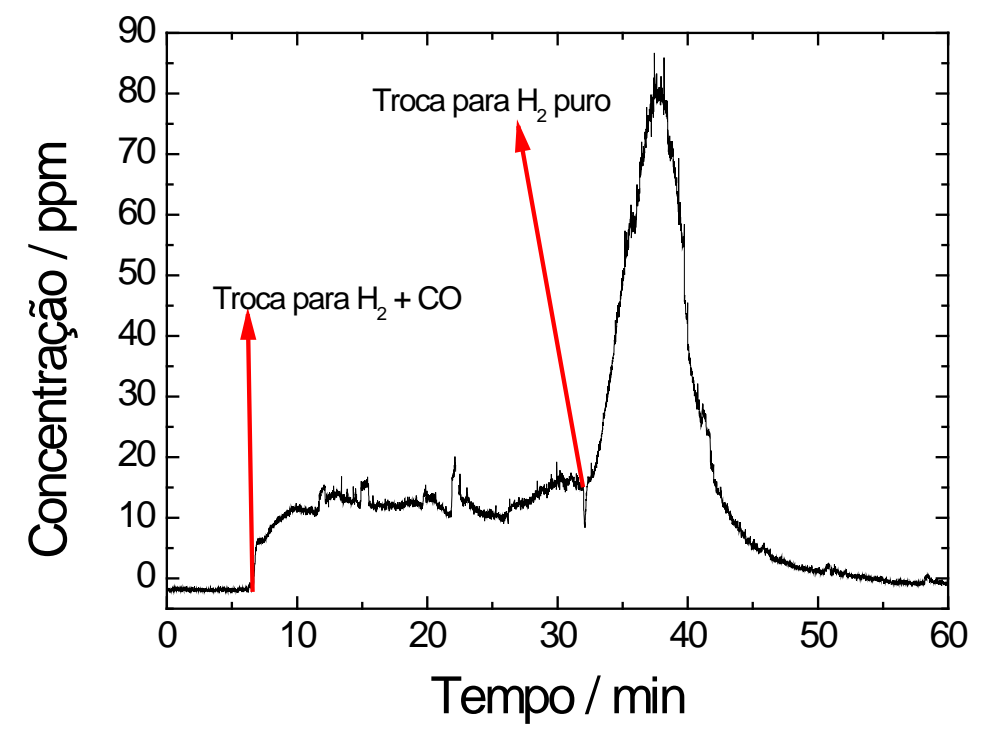

Figura 10: Perfil de produção de $\mathrm{CH}_{4}$ a $85^{\circ} \mathrm{C}$ em catalisador de Ru/C tratado termicamente e utilizado em CDG.

Este resultado mostra que houve uma melhora significativa na capacidade metanadora deste material a $85^{\circ} \mathrm{C}$. O perfil de metanação obtido nesta temperatura com o material tratado termicamente se assemelha muito ao obtido a $105{ }^{\circ} \mathrm{C}$ com Ru/C sem o tratamento térmico, porém, somente quando a temperatura reacional foi de $105^{\circ} \mathrm{C}$. Além da maior taxa de conversão de $\mathrm{CO}$ a $\mathrm{CH}_{4}$, o tratamento térmico proporcionou ao Ru/C a propriedade de promover a reação de metanação de uma maneira contínua. 
Ao elevar-se a temperatura da reação para $105{ }^{\circ} \mathrm{C}$, houve um aumento na produção de metano. Aproximadamente $80 \%$ do $\mathrm{CO}$ foi convertido $\mathrm{a}^{\mathrm{CH}_{4}}$ nessas condições, conforme ilustrado na Figura 11. Além disso, não houve produção transiente de metano ao se efetuar a troca do gás reacional, de $\mathrm{H}_{2}$ contendo $\mathrm{CO}$ para hidrogênio puro, como ocorreu a $85{ }^{\circ} \mathrm{C}$. Especula-se que nestas condições reacionais as espécies oxigenadas formadas pela adsorção dissociativa do CO sejam prontamente eliminadas, resultando em baixo recobrimento por espécies adsorvidas e proporcionando maior superfície reacional para a adsorção dissociativa do $\mathrm{H}_{2}$.

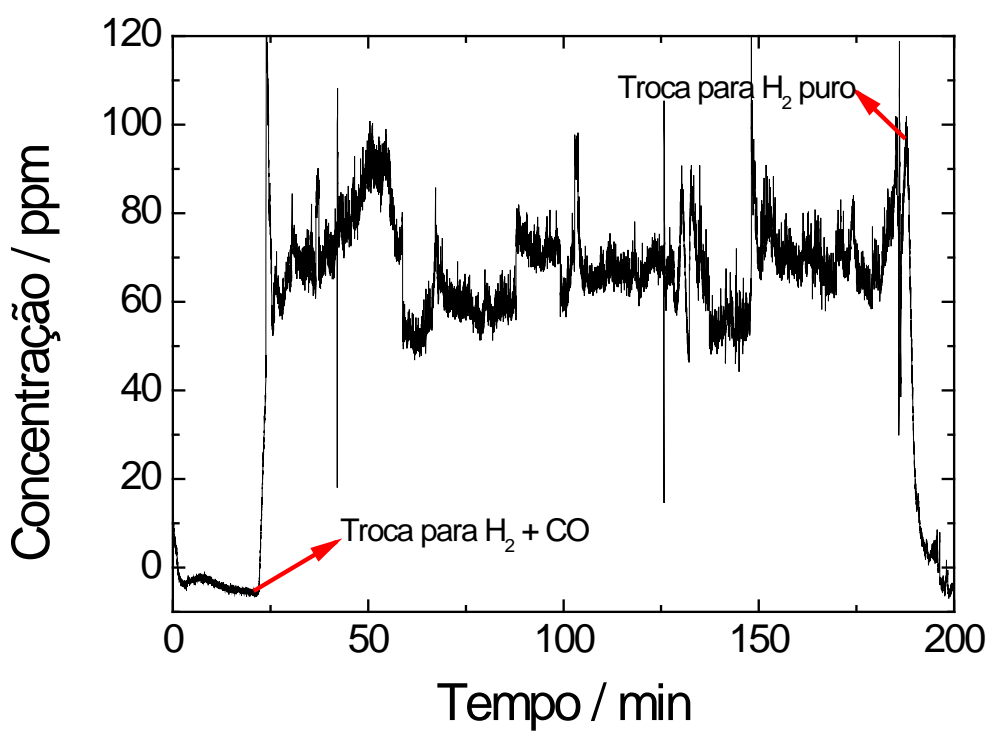

Figura 11: Perfil de produção de $\mathrm{CH}_{4}$ a $105^{\circ} \mathrm{C}$ em catalisador de $\mathrm{Ru} / \mathrm{C}$ tratado termicamente e utilizado em CDG.

Estas informações sobre produção de $\mathrm{CH}_{4}$ contínua e elevada após o tratamento térmico, juntamente com os dados obtidos por XPS possibilitam inferir que a espécie de Ru responsável pela metanação seja o Ru metálico. Além disso, observou-se a ausência do pico de energia de ligação referente às espécies oxidadas hidratadas de Ru nos espectros de XPS do material tratado termicamente. Esta informação pode indicar que essas espécies de Ru são responsáveis pela forte interação com espécies oxigenadas que bloqueiam a superfície e que, portanto, a sua ausência pode promover uma melhora na taxa reacional. 
Entretanto, mais experimentos seriam necessários para se estabelecer com clareza uma relação entre as espécies catalíticas e as espécies intermediárias reacionais.

\subsubsection{Curvas de polarização e de sobrepotencial anódico}

$\mathrm{Na}$ Figura 12 são apresentadas as curvas de polarização da célula a combustível e as curvas de sobrepotencial anódico quando foram utilizadas camadas difusoras preparadas pelo método convencional, contendo somente $\mathrm{C}$, e pelo método modificado, utilizando-se Ru/C. Os resultados obtidos para os materiais contendo $\mathrm{Pd}$ a $85{ }^{\circ} \mathrm{C}$ foram muito similares aos resultados obtidos com as camadas difusoras contendo somente Ru/C e por isso foram omitidos. Para a temperatura de $105^{\circ} \mathrm{C}$ foram somente levantadas as curvas de polarização em estado estacionário para o material de $\mathrm{Ru} / \mathrm{C}$, que apresentou melhor atividade frente à reação de metanação. Os dados das Figuras 12 referem-se ao material sem tratamento térmico.

A $85{ }^{\circ} \mathrm{C}$ a modificação da camada difusora não trouxe benefícios para 0 desempenho da célula, chegando até mesmo a piorar o desempenho quando densidades de corrente mais altas foram exigidas do sistema. Por outro lado, ao operar a $105{ }^{\circ} \mathrm{C}$, a célula a combustível exibiu desempenho superior quando da presença de Ru/C na camada difusora, como observado pelo menor incremento do sobrepotencial a partir de $0,5 \mathrm{~A} \mathrm{~cm}^{-2}$. Nas outras regiões da curva de sobrepotencial, o desempenho da camada difusora convencional e daquela contendo Ru/C foram semelhantes. 


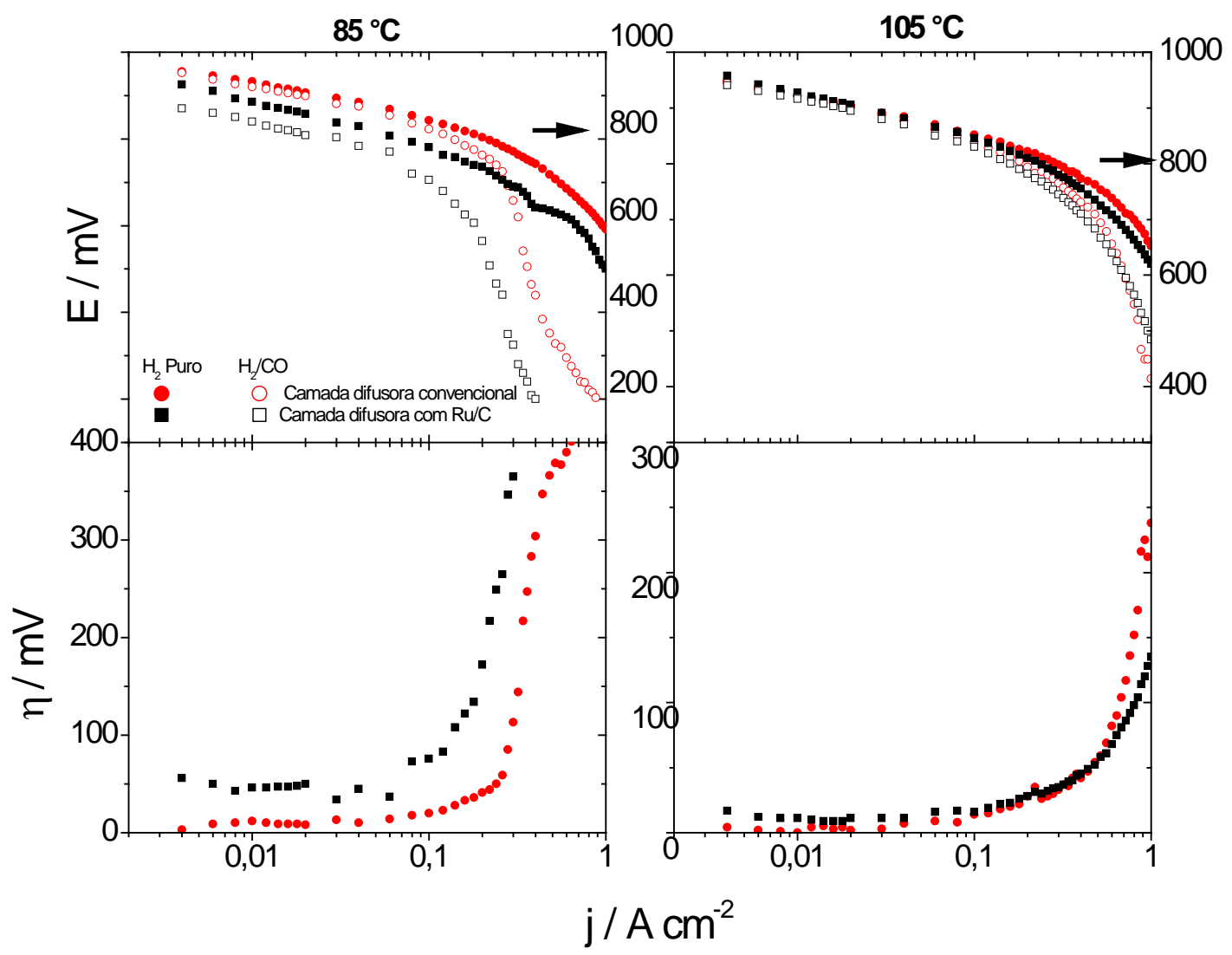

Figura 12: Comparação de curvas de sobrepotencial anódico para camada difusora contendo somente C e posteriormente Ru/C, em duas diferentes temperaturas.

Estes fatos podem ser explicados através da observação da produção de $\mathrm{CH}_{4}$ nas Figuras 8 e 9. Na Figura 8 , a $85^{\circ} \mathrm{C}$ nota-se que não houve produção contínua de metano em nenhum momento, além do que a presença de $\mathrm{Pd}$ no material $\mathrm{Ru} / \mathrm{C}$ não promoveu melhora no desempenho do sistema na remoção contínua do CO do gás de entrada no ânodo. Quando a célula operou a $105{ }^{\circ} \mathrm{C}$ observou-se uma melhora geral no desempenho do sistema, que pode ser explicada pela produção de metano em regime estacionário (Figura 9), reduzindo a pressão parcial de CO que penetra na camada catalítica, mitigando os efeitos de envenenamento por $\mathrm{CO}$. Como a produção de $\mathrm{CH}_{4}$ neste material não tratado foi baixa, da ordem de 15 ppm, o menor envenenamento por CO somente é observado quando maiores densidades de corrente, ou seja, maiores fluxos de reagentes são requeridos. 
Os resultados obtidos para Ru/C tratado termicamente serão discutidos na seção 4.4.2.

\subsection{Filtro de linha gasosa}

A célula a combustível de membrana de troca protônica apresenta limitações quanto à temperatura de operação. A membrana deve operar sempre em atmosfera saturada com água para que não ocorra seu ressecamento, o que inviabilizaria o mecanismo de transporte dos prótons. A partir de $100{ }^{\circ} \mathrm{C}$ a pressão de vapor da água cresce exponencialmente, sendo que já em $120{ }^{\circ} \mathrm{C}$ o sistema deve operar a 2 atm para saturar o gás de entrada com água. Outro fator importante é que a temperatura de transição vítrea da membrana de Nafion situa-se próxima de $130{ }^{\circ} \mathrm{C}$. Acima desta temperatura a membrana perde as características físicas necessárias para utilização em células a combustível.

Para contornar estes problemas e poder realizar experimentos em temperaturas mais elevadas foi utilizado um filtro de linha gasosa, que consistiu de um cilindro oco de aço poroso, dentro do qual o catalisador foi acomodado. Desta maneira, o gás fluiu para dentro do cilindro, passando pelo meio filtrante contendo catalisador e deixando o filtro depois de atravessar suas paredes porosas.

\subsubsection{Perfis de metanação}

\subsubsection{Efeito da Temperatura}

$\mathrm{Na}$ Figura 13 encontram-se os perfis de produção de metano para o filtro operando em diversas temperaturas com o catalisador Ru/C. No instante zero, somente $\mathrm{H}_{2}$ puro estava passando pelo filtro. A partir de $5 \mathrm{~min}$, trocou-se o gás de alimentação de $\mathrm{H}_{2}$ puro para $\mathrm{H}_{2}$ contendo 100 ppm de $\mathrm{CO}$. 


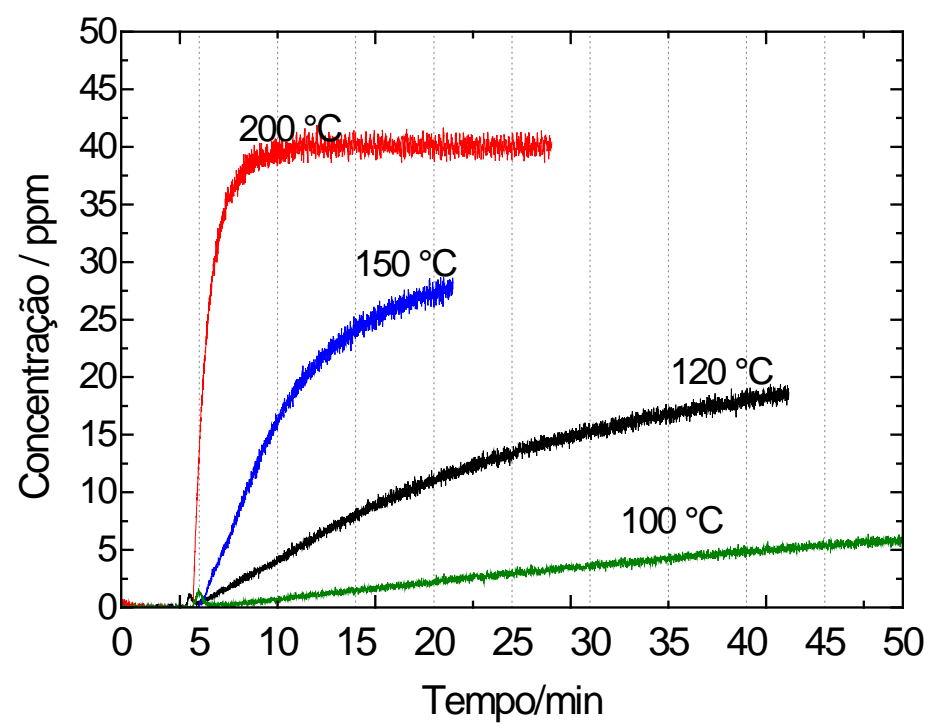

Figura 13: Conversão de $\mathrm{CO}$ a $\mathrm{CH}_{4}$ em Ru/C como preparado e acomodado num filtro de linha gasosa, em diversas temperaturas e sob fluxo de $\mathrm{H}_{2}$ contendo 100 ppm de $\mathrm{CO}$.

Exceto para a temperatura reacional de $100^{\circ} \mathrm{C}$, foi observada a produção de $\mathrm{CH}_{4}$ tendendo ao regime estacionário. O que mais diferencia os perfis nas diversas temperaturas de operação é o tempo em que o regime estacionário é alcançado e a quantidade de metano produzida por minuto. A $200{ }^{\circ} \mathrm{C}$ a produção de metano alcança seu máximo (40 ppm) quase no mesmo instante em que ocorre a troca de $\mathrm{H}_{2}$ puro para $\mathrm{H}_{2}$ contendo 100 ppm de $\mathrm{CO}$, convertendo cerca de $40 \%$ do $\mathrm{CO}$ em $\mathrm{CH}_{4}$.

\subsubsection{Efeito do tratamento térmico}

Após os testes nas diferentes temperaturas, os catalisadores Ru/C e $\mathrm{Ru}_{7} \mathrm{Pd}_{3} / \mathrm{C}$ foram tratados a $150{ }^{\circ} \mathrm{C}$ sob fluxo de $\mathrm{H}_{2}$ saturado com água, a 4,8 bar durante $5 \mathrm{~h}$, dentro do próprio filtro. Após este período o filtro foi novamente aquecido a $200{ }^{\circ} \mathrm{C}$ sob fluxo de hidrogênio seco e após 1 h o gás de alimentação foi 
trocado para $\mathrm{H}_{2}$ contendo 100 ppm de CO, para avaliar o poder de metanação destes materiais tratados. Na Figura 14 encontram-se os perfis obtidos.

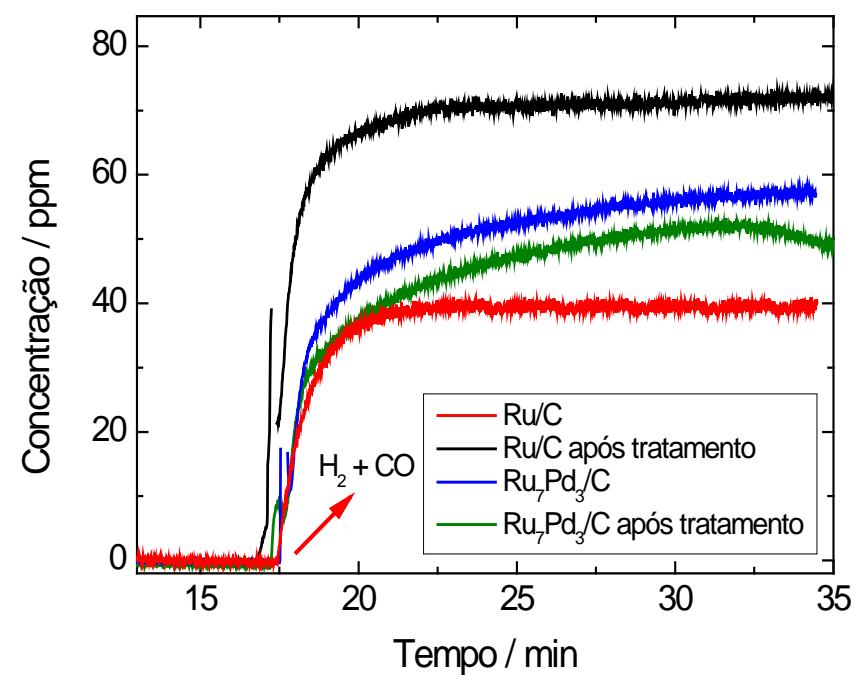

Figura 14: Perfis de conversão de $\mathrm{CO}$ a $\mathrm{CH}_{4}$ em filtro de linha gasosa a $200{ }^{\circ} \mathrm{C}$ para os catalisadores antes e após o tratamento térmico

Similarmente ao que já foi observado quando os catalisadores foram utilizados em CDG, o tratamento térmico influenciou positivamente a reação de metanação do $\mathrm{CO}$, em particular quando foi realizada sobre o material de $\mathrm{Ru} / \mathrm{C}$. Previamente ao tratamento, a taxa de conversão de $\mathrm{CO}$ a $\mathrm{CH}_{4}$ a $200{ }^{\circ} \mathrm{C}$ foi de $40 \%$. Após o tratamento, o novo material passou a converter aproximadamente $76 \%$ do $\mathrm{CO}$ em $\mathrm{CH}_{4}$ sob as mesmas condições. Porém, quando este mesmo tratamento foi realizado com o catalisador de $\mathrm{Ru}_{7} \mathrm{Pd}_{3} / \mathrm{C}$, não houve melhora observável. $A$ taxa de metanação do CO permaneceu praticamente inalterada, sendo que as diferenças situam-se na faixa do limite de detecção do espectrômetro de massas. No item 4.2.1.3 foram discutidos alguns dos prováveis motivos para explicar tal comportamento, sendo a presença de maior quantidade de Ru metálico a provável responsável pela ativação do $\mathrm{Ru} / \mathrm{C}$, e no caso do $\mathrm{Ru}_{7} \mathrm{Pd}_{3} / \mathrm{C}$, as espécies com elevado estado de oxidação, portadoras de espécies oxigenadas e que não foram removidas com o tratamento térmico, são as prováveis responsáveis pelo pior desempenho deste material. 


\subsubsection{Curvas de sobrepotencial}

$\mathrm{Na}$ Figura 15 estão dispostas de maneira comparativa as curvas de sobrepotenciais para a célula a combustível empregando o material de Ru/C em camada difusora e, após tratamento térmico, empregado também em filtro de linha gasosa, além da camada difusora. O filtro de linha operou em $200{ }^{\circ} \mathrm{C}$ e as curvas correspondem ao desempenho de uma célula unitária operando a $85^{\circ} \mathrm{C}$.

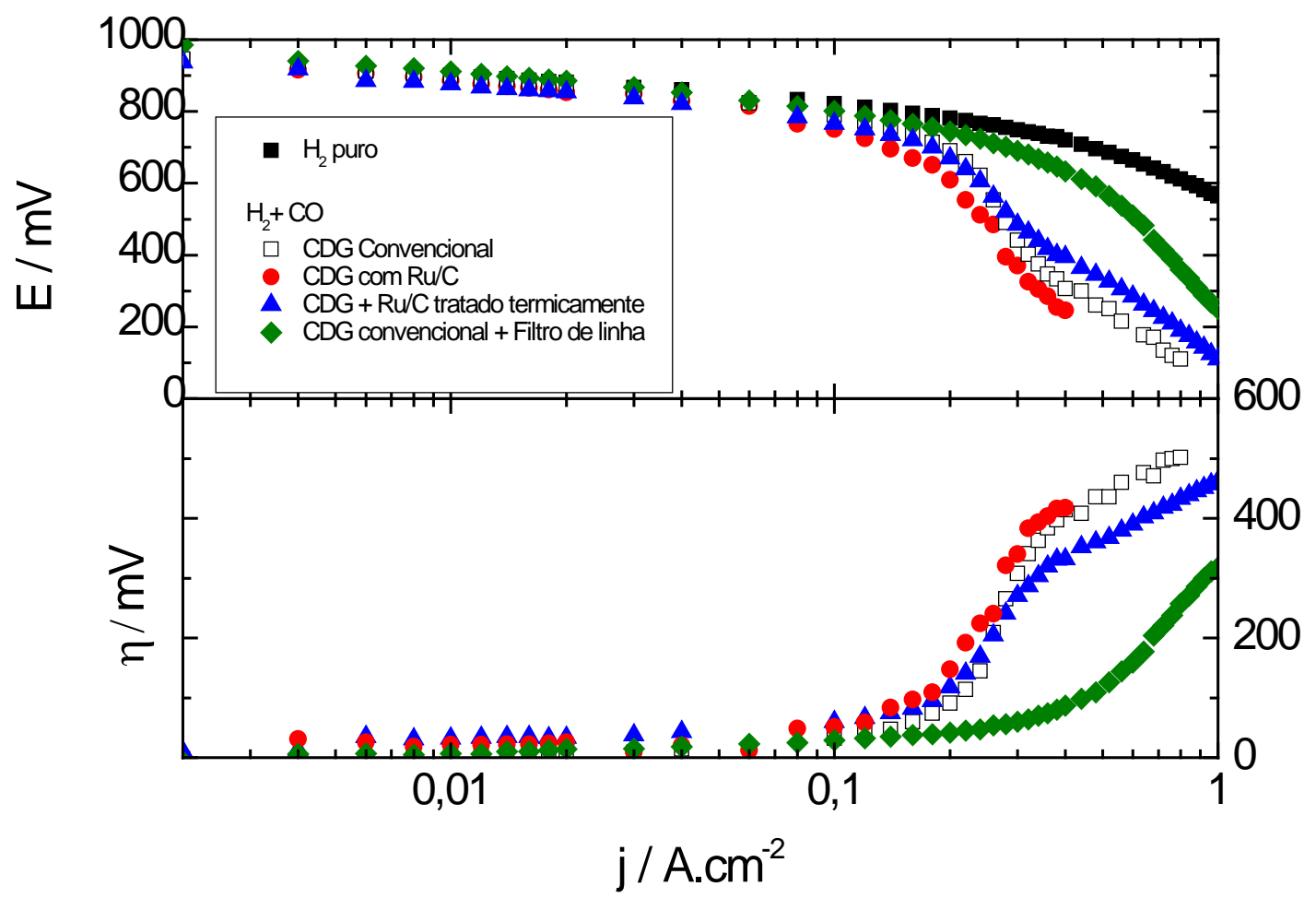

Figura 15: Curvas de polarização e de sobrepotencial anódico para células a combustível operando a $85^{\circ} \mathrm{C}$ e empregando Ru/C para a conversão do $\mathrm{CO}$ em $\mathrm{CH}_{4}$.

Quando o material Ru/C submetido ao tratamento térmico foi utilizado no filtro de linha gasosa, acoplado antes do ânodo, a célula a combustível apresentou um desempenho consideravelmente superior ao das outras configurações. Operando nesta configuração, foi possível à célula apresentar sobrepotencial de $100 \mathrm{mV}$ em densidade de corrente de 0,4 $\mathrm{A} \mathrm{cm}^{-2}$. Este incremento de desempenho é correlacionado com a alta eficiência do catalisador utilizado no filtro em converter 
$\mathrm{CO}$ a $\mathrm{CH}_{4}$, como ilustrado na Figura 14, chegando a converter 76\% (76 ppm dos 100 ppm iniciais) do CO presente, reduzindo a pressão parcial de CO na camada catalítica e, portanto, liberando mais sítios para a oxidação do $\mathrm{H}_{2}$.

Quando os materiais foram utilizados na camada difusora não houve alteração nas curvas de polarização, exceto quando Ru/C tratado termicamente foi utilizado. Neste caso, a partir de 0,3 A. $\mathrm{cm}^{-2}$ houve uma diminuição no sobrepotencial, se comparado com as camadas difusoras contendo outros materiais. Esta melhora no desempenho se deve ao fato de o catalisador Ru/C tratado termicamente produzir metano em regime contínuo, mesmo quando a temperatura do meio reacional foi $85^{\circ} \mathrm{C}$, conforme foi observado na Figura 10 .

Estes dados demonstram que Ru/C pode ser aplicado em sistemas com células a combustível de baixa temperatura para a remoção do $\mathrm{CO}$ presente no hidrogênio. Porém, apesar de o tratamento térmico ter demonstrado ser eficiente para melhorar as características deste catalisador, mais estudos são necessários a fim de viabilizar a sua utilização em CDG.

4.4. O efeito da presença de $\mathrm{CO}_{2}$

Com a finalidade de se aproximar o sistema da célula a combustível de uma situação operacional, um pouco mais realista, foi pesquisado o efeito da presença de $\mathrm{CO}_{2}$ no gás de alimentação anódica. Portanto, os catalisadores também foram estudados na presença de $\mathrm{H}_{2}, \mathrm{CO}, \mathrm{CO}_{2}$ e vapor de água, uma composição similar à do hidrogênio disponível comercialmente, quando obtido via reforma catalítica. Para se estudar também a seletividade do catalisador de Ru/C perante a metanação do $\mathrm{CO}$ na presença de $\mathrm{CO}_{2}$, experimentos similares aos realizados somente com $\mathrm{CO}$ e $\mathrm{H}_{2}$ foram também feitos com $\mathrm{CO}_{2}$, sendo os resultados apresentados a seguir. 


\subsubsection{Perfis de metanação}

\subsubsection{Metanação de $\mathrm{CO}$ e $\mathrm{CO}_{2}$ em filtro de linha gasosa}

Na Figura 16 encontram-se os gráficos de produção de metano quando o hidrogênio continha ou 75 ppm de $\mathrm{CO}$ ou $25 \%$ de $\mathrm{CO}_{2}$ ou ambos, sendo indicados os momentos em que o gás de alimentação anódica foi alterado. O catalisador utilizado neste caso foi o Ru/C tratado termicamente, pois como já foi observado este material foi o que apresentou o melhor desempenho para a reação de metanação. Este material foi acomodado no filtro de linha de gases, de maneira que todo hidrogênio deveria passar por ele antes de entrar na câmara anódica. A temperatura do reator foi de $200{ }^{\circ} \mathrm{C}$ em todos os casos.
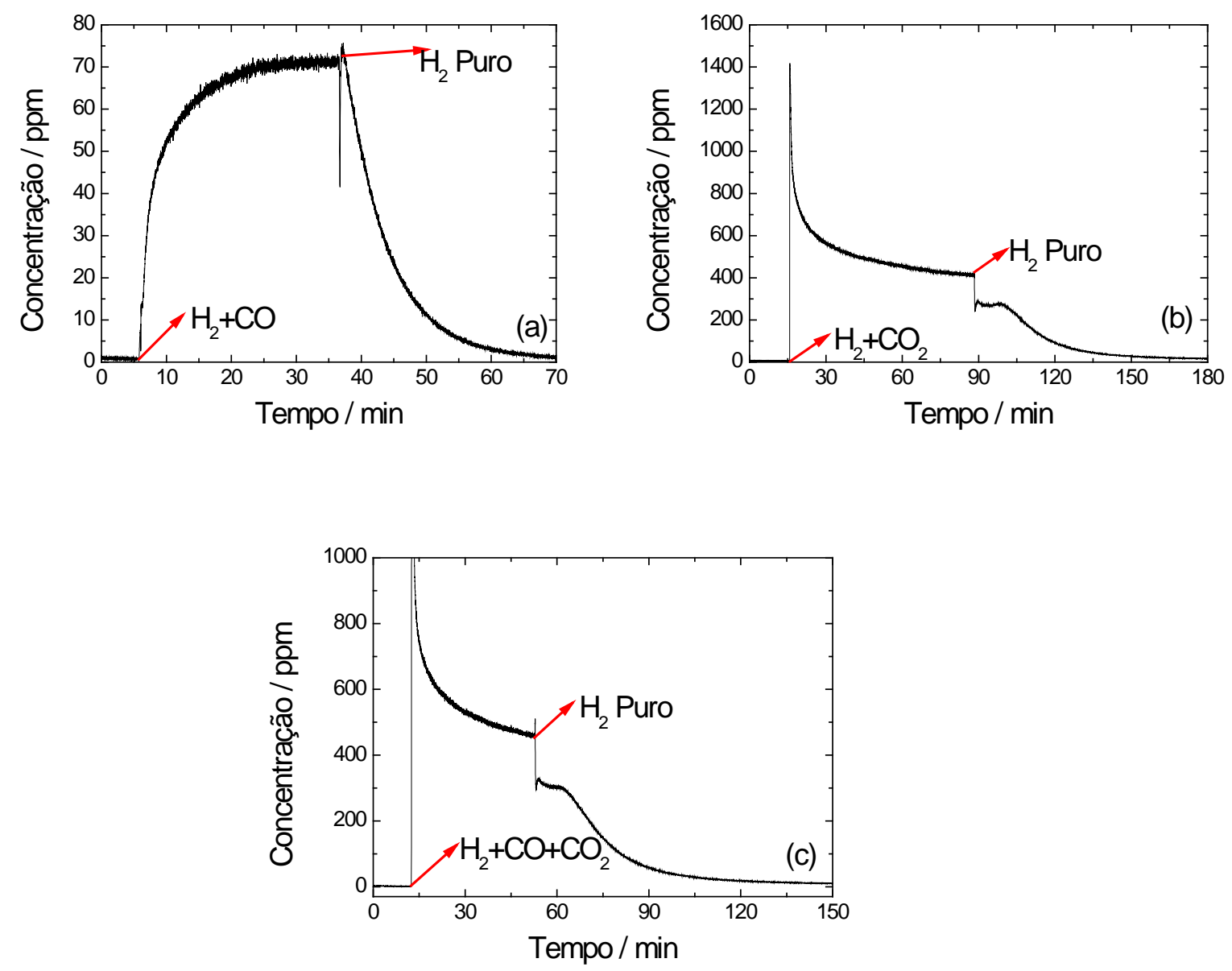

Figura 16: Curvas de produção de $\mathrm{CH}_{4}$ quando $\mathrm{Ru} / \mathrm{C}$ tratado termicamente foi utilizado em filtro de linha de gases, operando a $200^{\circ} \mathrm{C}$, e o gás de alimentação foi (a) $\mathrm{H}_{2}$ contendo $75 \mathrm{ppm}$ de $\mathrm{CO}$ (b) $\mathrm{H}_{2}$ contendo $25 \%$ de $\mathrm{CO}_{2}$ e (c) $\mathrm{H}_{2}$ contendo $25 \%$ de $\mathrm{CO}_{2}+75$ ppm de CO. 
Observando-se a Figura 16a nota-se que há a formação de aproximadamente 75 ppm de $\mathrm{CH}_{4}$ em regime estacionário. Isto significa que os $75 \mathrm{ppm}$ de $\mathrm{CO}$ presentes inicialmente foram totalmente convertidos a metano, promovendo a completa limpeza do hidrogênio. Na Figura 16b pode-se observar que $\mathrm{CO}_{2}$ também é convertido em $\mathrm{CH}_{4}$ nessas condições. Esta conversão ocorre provavelmente por dois intermediários: um fortemente adsorvido e o outro fracamente adsorvido. A presença do intermediário fracamente adsorvido é notada ao se remover $0 \mathrm{CO}_{2}$ do fluxo gasoso. Neste momento há uma abrupta redução na concentração de metano, indicando que este metano estava sendo prontamente formado a partir do $\mathrm{CO}_{2}$, não havendo forte interação com o material. Porém, a produção não cessa imediatamente, ocorrendo formação de $\mathrm{CH}_{4}$ durante certo tempo. Esta formação de $\mathrm{CH}_{4}$ mesmo na ausência de reagente no fluxo gasoso sugere que há na superfície do catalisador algum intermediário fortemente adsorvido e precursor do produto reacional. Quando se adicionou $\mathrm{CO}$ à mistura de $\mathrm{CO}_{2}$ e hidrogênio (Figura 16c), não foi observada alteração no perfil de produção de metano, nem mesmo na região de produção por intermediários fortemente adsorvidos. Este fato pode indicar que o intermediário fortemente adsorvido é similar à espécie superficial formada pela adsorção do CO no catalisador.

\subsubsection{Metanação de $\mathrm{CO}$ e $\mathrm{CO}_{2}$ em CDG}

A Figura 17 apresenta a produção de metano para diversas composições gasosas como reagentes, a $85^{\circ} \mathrm{C}$, utilizando-se $\mathrm{Ru} / \mathrm{C}$ tratado termicamente utilizado na CDG. Estes dados mostram que ao se utilizar camada difusora anódica modificada pela adição de Ru/C tratado termicamente há produção de 50 ppm de $\mathrm{CH}_{4}$ a $85{ }^{\circ} \mathrm{C}$ quando $25 \%$ de $\mathrm{CO}_{2}$ estavam misturados com $\mathrm{H}_{2}$. Verifica-se também que, quando $\mathrm{CO}_{2}$ e $\mathrm{CO}$ estiveram presentes no hidrogênio, a produção de $\mathrm{CH}_{4}$ manteve-se inalterada. Entretanto, quando esta mistura foi substituída por $\mathrm{H}_{2}$ puro, foi observado um pico transiente de produção de $\mathrm{CH}_{4}$, não observado quando somente $\mathrm{CO}_{2}$ estava presente no hidrogênio. Este fato pode indicar que, apesar da metanação do $\mathrm{CO}_{2}$ ocorrer através da formação de um intermediário similar ao $\mathrm{CO}$, 
este intermediário é originado em um sítio diferente no Ru/C de onde se adsorve o CO presente no fluxo de hidrogênio.
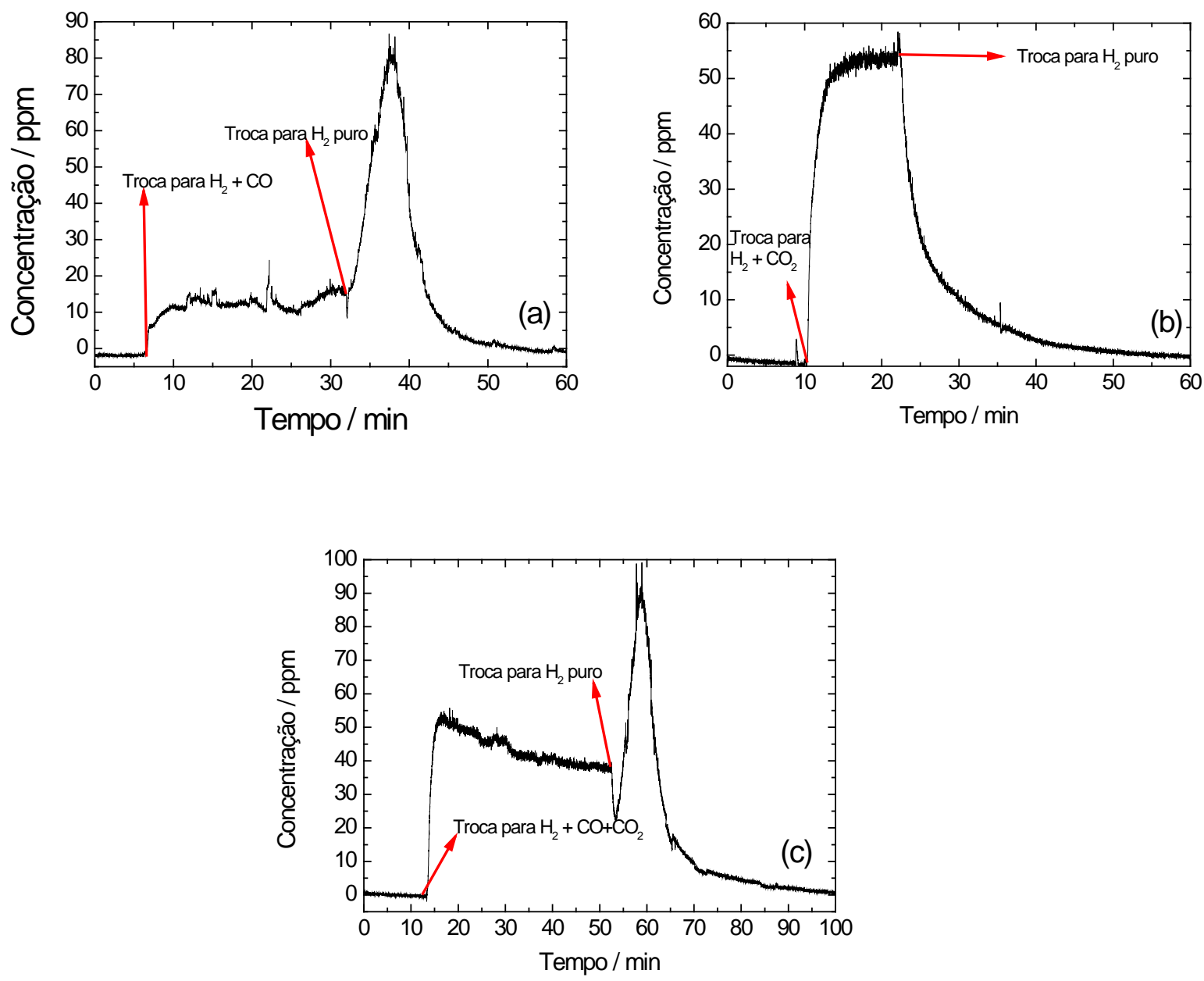

Figura 17: Curvas de produção de $\mathrm{CH}_{4}$ quando $\mathrm{Ru} / \mathrm{C}$ tratado termicamente foi utilizado em CDG de ânodo de célula a combustível, operando a $85^{\circ} \mathrm{C}$, e o gás de alimentação anódica foi (a) $\mathrm{H}_{2}$ contendo $75 \mathrm{ppm}$ de $\mathrm{CO}$ (b) $\mathrm{H}_{2}$ contendo $25 \%$ de $\mathrm{CO}_{2}$ e (c) $\mathrm{H}_{2}$ contendo $25 \%$ de $\mathrm{CO}_{2}+75$ ppm de CO.

Na Figura 18 estão os gráficos de produção de metano em misturas contendo $\mathrm{CO}, \mathrm{H}_{2}$ e $\mathrm{CO}_{2}$, tal qual exposto na Figura anterior, porém, na temperatura de $105^{\circ} \mathrm{C}$. Este acréscimo de $20^{\circ} \mathrm{C}$ possibilitou uma elevação significativa na taxa reacional da conversão de $\mathrm{CO}$ em $\mathrm{CH}_{4}$. A $85^{\circ} \mathrm{C}$ produzia-se somente $10 \mathrm{ppm}$ de metano, que passou para 70 a 75 ppm a $105{ }^{\circ} \mathrm{C}$, o que significa que praticamente todo $\mathrm{CO}$ foi removido. Observa-se também que, consistentemente, nesta temperatura inexiste o transiente de produção de metano a partir do $\mathrm{CO}$. Quando $\mathrm{CO}_{2}$ foi adicionado à 
mistura de $\mathrm{CO}$ e $\mathrm{H}_{2}$, houve a produção de $\mathrm{CH}_{4}$ de maneira quase que aditiva às produções observadas somente para $\mathrm{CO}$ e somente para $\mathrm{CO}_{2}$ quando presentes no hidrogênio. Esta observação é consistente com aquela feita anteriormente de que a produção de $\mathrm{CH}_{4}$ se dá por mecanismos distintos quando $\mathrm{CO}$ e $\mathrm{CO}_{2}$ são os reagentes precursores. Assim o metano seria produzido por duas rotas independentes e que, portanto, não influenciam na taxa reacional uma da outra.
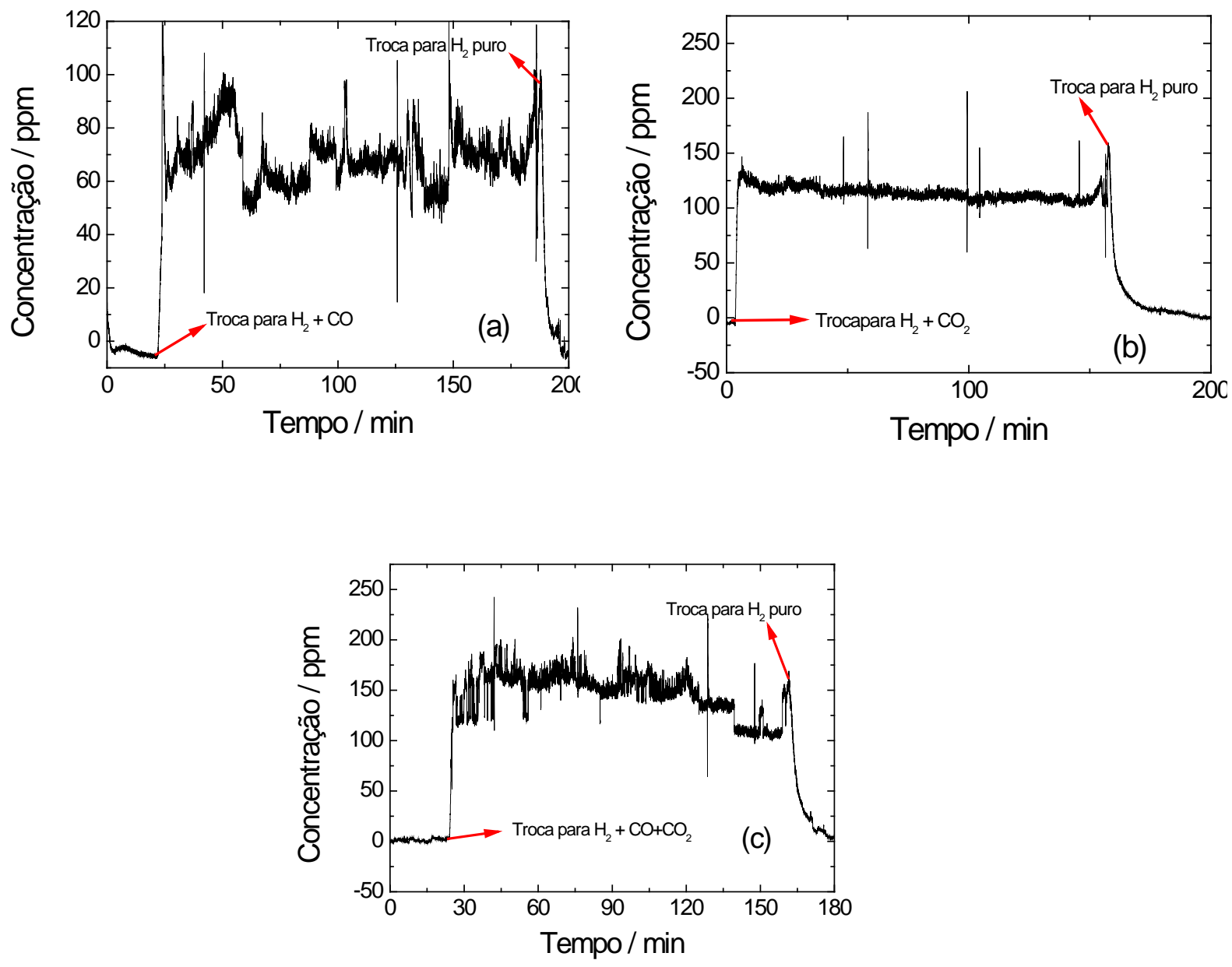

Figura 18: Curvas de conversão de $\mathrm{CO}$ a $\mathrm{CH}_{4}$ quando $\mathrm{Ru} / \mathrm{C}$ tratado termicamente foi utilizado em CDG de ânodo de célula a combustível, operando a $105^{\circ} \mathrm{C}$, e o gás de alimentação anódica foi (a) $\mathrm{H}_{2}$ contendo 75 ppm de $\mathrm{CO}$ (b) $\mathrm{H}_{2}$ contendo $25 \%$ de $\mathrm{CO}_{2}$ e (c) $\mathrm{H}_{2}$ contendo $25 \%$ de $\mathrm{CO}_{2}+75$ ppm de $\mathrm{CO}$. 


\subsubsection{Curvas de Polarização em estado estacionário}

Na Figura 19 são mostradas as curvas de polarização da célula e de sobrepotencial do ânodo quando o hidrogênio continha algum contaminante. Nota-se que a presença do $\mathrm{CO}_{2}$ no fluxo gasoso conjuntamente com o hidrogênio alterou, embora de maneira não muito significativa, os perfis das curvas de polarização em estado estacionário tanto para CDG preparadas pelo método convencional quanto para CDG preparadas com Ru/C tratado termicamente. No caso do eletrodo convencional houve um ligeiro decréscimo de atividade do eletrodo na presença de $\mathrm{CO}_{2}$ tanto na ausência como na presença de $\mathrm{CO}$. Este resultado evidencia uma contaminação do eletrodo de Pt possivelmente por CO gerado pela RWGSR neste mesmo catalisador. Já no caso do eletrodo com Ru/C este efeito é um pouco minimizado pela conversão do $\mathrm{CO}$ e do $\mathrm{CO}_{2} \mathrm{a} \mathrm{CH}_{4}$, conforme observado pelos resultados de espectrometria de massa.

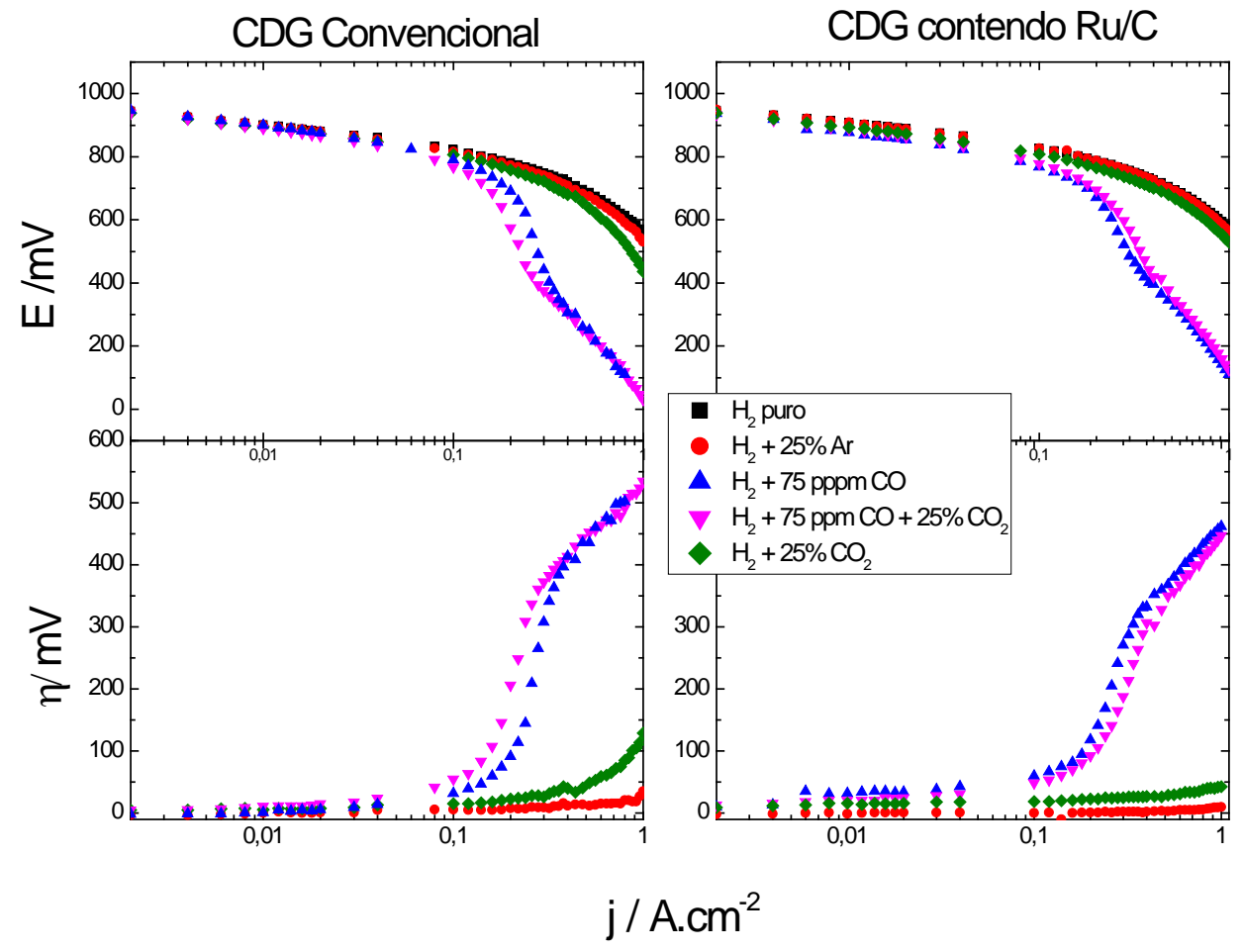

Figura 19: Curvas de polarização de células a combustível operando a $85^{\circ} \mathrm{C}$ e com camada difusora contendo Ru/C tratado termicamente. Além disso, estão representadas também as curvas de polarização obtidas com hidrogênio contendo $\mathrm{CO}$ e também $\mathrm{CO}_{2}$. 
Na Figura 20 estão as curvas de polarização e de sobrepotencial anódico, obtidas de maneira similar à Figura 19, porém para experimentos realizados numa temperatura $20^{\circ} \mathrm{C}$ mais elevada, ou seja, a $105^{\circ} \mathrm{C}$.

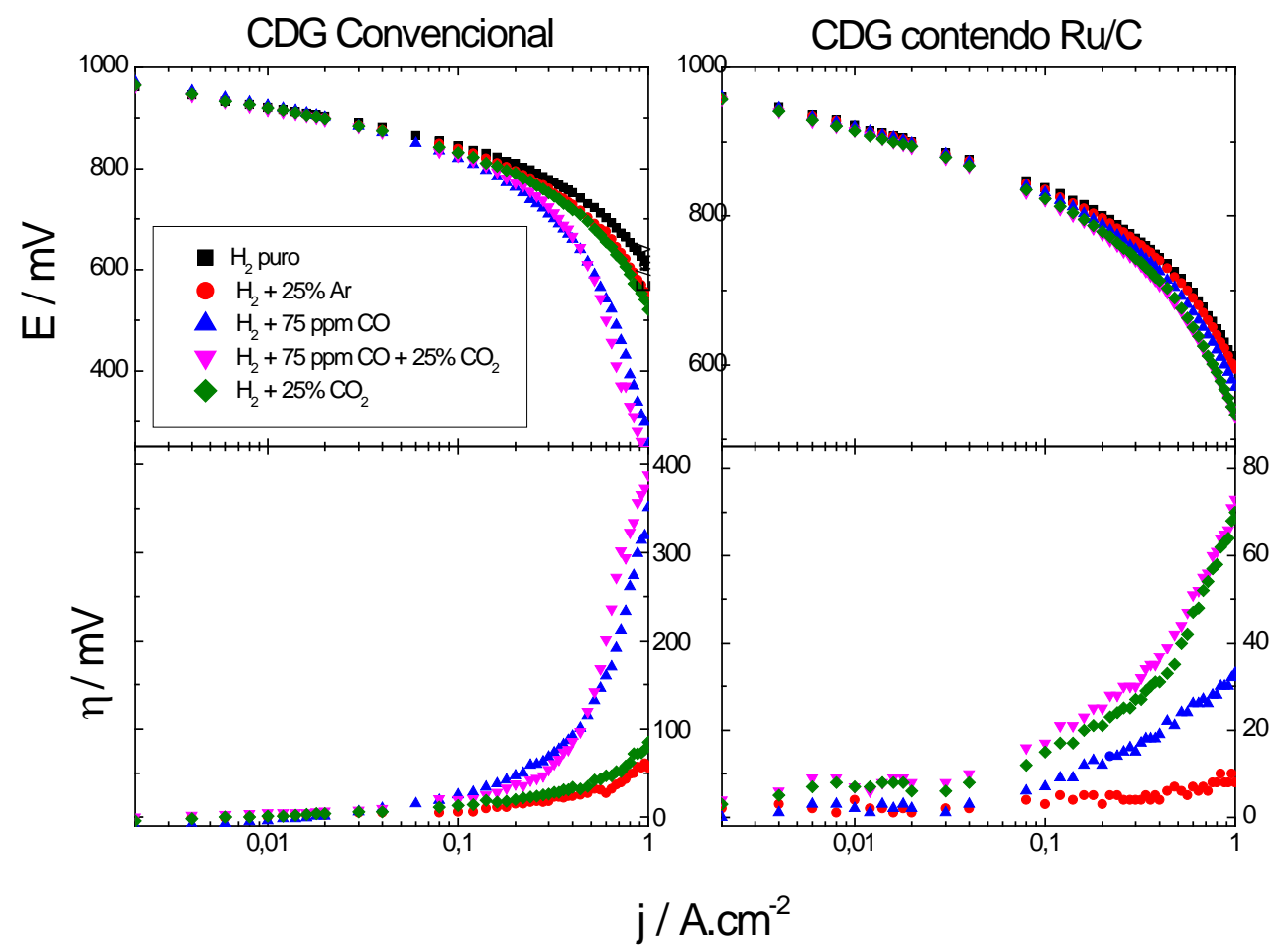

Figura 20: Curvas de polarização de células a combustível operando a $105^{\circ} \mathrm{C}$ e com camada difusora contendo Ru/C tratado termicamente. Além disso estão representadas também as curvas de polarização obtidas com hidrogênio contendo $\mathrm{CO}$ e também $\mathrm{CO}_{2}$

Nota-se inicialmente que o efeito da presença de $\mathrm{CO}_{2}$ é pouco significativo para o eletrodo contendo apenas carbono na camada difusora. No entanto, quando CO foi adicionado, ocorreu um decréscimo no potencial de célula, tal qual a $85^{\circ} \mathrm{C}$, porém, não tão pronunciado, e cujo provável responsável é a forte interação do CO pela $\mathrm{Pt}$, reduzindo os sítios para a oxidação de $\mathrm{H}_{2}$, como já explicado.

Observando-se as curvas de polarização para o sistema com Ru/C nota-se que quando somente $\mathrm{CO}$ e hidrogênio estiveram presentes o sobrepotencial anódico foi menor do que quando somente $\mathrm{o}_{2}$ e $\mathrm{CO}_{2}$ foram utilizados. Estes resultados são coerentes com o fato de que quando a célula operou a $105{ }^{\circ} \mathrm{C}$ houve produção 
contínua de $\mathrm{CH}_{4}$ em todas as condições de presença de contaminantes, sendo esta produção maior quando houve a presença somente de $\mathrm{CO}_{2}$ no hidrogênio, se comparado com a produção de $\mathrm{CH}_{4}$ no fluxo de $\mathrm{H}_{2}$ somente com $\mathrm{CO}$, e mais elevada ainda quando estes dois contaminantes foram incorporados conjuntamente ao $\mathrm{H}_{2}$. Porém, devido à reduzida quantidade de $\mathrm{CO}$, se comparado à quantidade utilizada de $\mathrm{CO}_{2}$, a produção de $\mathrm{CH}_{4}$ foi capar de remover praticamente todo contaminante, o que explica os menores sobrepotenciais obtidos.

$\mathrm{Na}$ presença de $\mathrm{CO}_{2}$, é possível que ocorra a reversão da reação deslocamento gás-água, tanto em Pt quanto em $\mathrm{Ru}$, produzindo $\mathrm{CO}$ a partir do $\mathrm{CO}_{2}$. A ocorrência desta reação tem sido inequivocamente comprovada para o eletrodo de $\mathrm{P}^{\left[{ }^{[74]}\right.}$ e é a provável responsável pela redução no desempenho que foi observada no sistema que utilizou camada difusora convencional.

Quando $\mathrm{CO}$ foi adicionado à mistura de $\mathrm{CO}_{2}$ e $\mathrm{H}_{2}$, não houve piora de desempenho, pois Ru/C converte eficientemente $\mathrm{CO}$ a $\mathrm{CH}_{4}$ por rota catalítica diferente daquela para a conversão de $\mathrm{CO}_{2}$ a $\mathrm{CH}_{4}$. Portanto, este catalisador apresenta elevado potencial de utilização para a purificação de gás de síntese com finalidade de utilização em célula a combustível, pois converte $\mathrm{CO}$ a $\mathrm{CH}_{4} \mathrm{com}$ elevada taxa reacional, mesmo na presença de $\mathrm{CO}_{2}$ e em temperaturas tão baixas quanto $105^{\circ} \mathrm{C}$. 


\section{CONCLUSÕES}

A $85{ }^{\circ} \mathrm{C}$ o material Ru/C como preparado somente promove a metanação do CO na presença de hidrogênio quando o gás de alimentação anódica é trocado de $\mathrm{H}_{2}$ de alta pureza para $\mathrm{H}_{2} / \mathrm{CO}$ e vice-versa, ou seja, em situações transientes. Porém, a $105{ }^{\circ} \mathrm{CH}_{4}$ é produzido continuamente, embora com baixa taxa de conversão, mas o suficiente para se observar uma melhora no desempenho da célula. Quando Pd foi adicionado ao catalisador, o único efeito foi a diminuição na cinética de metanação, o que indica que este material retarda a reação de metanação nas condições estudadas e, da maneira como se estruturou no catalisador, não foi eficaz como um promotor da redução do CO.

$\mathrm{O}$ tratamento térmico melhorou a atividade do material $\mathrm{Ru} / \mathrm{C}$, que passou a reduzir o $\mathrm{CO}$ de maneira constante mesmo a $85{ }^{\circ} \mathrm{C}$. Entretanto, os melhores resultados de metanação foram obtidos quando este material esteve presente em CDG, a $105^{\circ} \mathrm{C}$ e quando foi utilizado em filtro de linha gasosa, promovendo esta reação a $200{ }^{\circ} \mathrm{C}$, mostrando a viabilidade técnica para se utilizar $\mathrm{Ru} / \mathrm{C}$ tratado termicamente para remover o $\mathrm{CO}$ de uma célula funcionando em baixas temperaturas. Esta maior atividade perante a reação de metanação se refletiu na diminuição do sobrepotencial anódico das curvas de polarização em estado estacionário, devido à remoção do CO do hidrogênio combustível.

Os efeitos observados nas curvas de polarização, ao adicionar-se $\mathrm{CO}_{2}$ à mistura gasosa anódica de uma célula com CDG convencional, foram decorrentes da diminuição do desempenho eletrocatalítico do eletrodo, provavelmente pela produção de CO no catalisador de Pt pela RWGSR. Mesmo utilizando-se Ru/C na CDG, a $85^{\circ} \mathrm{C}$ não houve produção de $\mathrm{CH}_{4}$ apreciável para melhorar o desempenho da célula. Quando CDG modificada foi utilizada a $105^{\circ} \mathrm{C}$ com hidrogênio contendo $\mathrm{CO}_{2}$ houve uma piora no desempenho se comparado à célula utilizando somente CO. Esta piora também pode ser atribuída à ocorrência da RWGSR no catalisador de Pt. Entretanto, mesmo com esta piora no desempenho, a célula a combustível operou de maneira mais eficiente do que nas outras configurações, comprovando, portanto, a viabilidade técnica em se utilizar este catalisador em um sistema prático. 


\section{REFERÊNCIAS BIBLIOGRÁFICAS}

1 SOLOMON, S.; QIN, D.; MANNING, M.; CHEN, Z.; MARQUIS, M.; AVERYT, K.B.; TIGNOR, M.; MILLER, H.L. Climate change 2007: The physical science basis. In: SOLOMON, S., D. QIN, M. MANNING, Z. CHEN, M. MARQUIS e K.B. AVERYT, M. T. A. H. L. M. Fourth assessment report of the intergovernmental panel on climate change. New York: Cambridge University, 2007. p. 95-99.

2 ORGANIZATION OF THE PETROLEUM EXPORTING COUNTRIES (OPEC). World oil outlook 2012. Vienna, Austria, 2012. p. 25-71.

3 EDOPKA, D. A.; AGHEYISI, J. E. Evaluation of environmental and social impact of crude oil exploitation in delta state, Nigeria. Journal of Sustainable Development and Environmental Protection, v. 2, n. 3, p. 29, 2012.

4 ROCHA, A. F.; GOY, L. ONS aciona térmicas para garantir abastecimento de energia. O Estado de Sâo Paulo, São Paulo, 2012. Disponível em: < http://www.estadao.com.br/noticias/geral,ons-aciona-termicas-para-garantirabastecimento-de-energia,947498,0.htm >. Acesso em: 21 fev. 2013.

5 INTERNATION ENERGY AGENCY (IEA). Medium-term oil\&gas markets. Paris, 2010. p. $19-25$.

6 RAJ, N. T.; INIYAN, S.; GOIC, R. A review of renewable energy based cogeneration technologies. Renewable and Sustainable Energy Reviews, v. 15, n. 8, p. 3640-3648, 2011.

7 SOBRINO, F. H.; MONROY, C. R.; PÉREZ, J. L. H. Biofuels and fossil fuels: Life Cycle Analysis (LCA) optimisation through productive resources maximisation.

Renewable and Sustainable Energy Reviews, v. 15, n. 6, p. 2621-2628, 2011.

8 PHALAN, B. The social and environmental impacts of biofuels in Asia: An overview. Applied Energy, v. 86, p. S21-S29, 2009.

9 GAO, F.; ZHAO, L. E.; WANG, X. The research review about the effect of bio-fuel development on agricultural market and agriculture. Agriculture and Agricultural Science Procedia, v. 1, p. 488-494, 2010.

10 BAHADORI, A.; NWAOHA, C. A review on solar energy utilisation in Australia. Renewable and Sustainable Energy Reviews, v. 18, p. 1-5, 2013.

11 SUN, X.; HUANG, D.; WU, G. The current state of offshore wind energy technology development. Energy, v. 41, n. 1, p. 298-312, 2012.

12 HEPBASLI, A. Development of geothermal energy utilization in Turkey: a review. Renewable and Sustainable Energy Reviews, v. 8, n. 5, p. 433-460, 2004. 
13 WANG, S.; YUAN, P.; LI, D.; JIAO, Y. An overview of ocean renewable energy in China. Renewable and Sustainable Energy Reviews, v. 15, n. 1, p. 91-111, 2011.

14 SHEINBAUM-PARDO, C.; RUIZ, B. J. Energy context in Latin America. Energy, v. 40, n. 1, p. 39-46, 2012.

15 VON HIPPEL, D.; SAVAGE, T.; HAYES, P. Overview of the Northeast Asia energy situation. Energ Policy, v. 39, n. 11, p. 6703-6711, 2011.

16 ANDÚJAR, J. M.; SEGURA, F. Fuel cells: history and updating. A walk along two centuries. Renewable and Sustainable Energy Reviews, v. 13, n. 9, p. 2309-2322, 2009.

17 DUPONT FUEL CELLS. Dupont nafion PFSA membranes. 2009. Disponível em: <http://www2.dupont.com/FuelCells/en_US/assets/downloads/dfc101.pdf>. Acesso em: 29 jun. 2013.

$18 \mathrm{HOU}, \mathrm{Y}$.; WANG, B.; YANG, Z. A method for evaluating the efficiency of PEM fuel cell engine. Applied Energy, v. 88, n. 4, p. 1181-1186, 2011.

19 YAMADA, N.; MOHAMAD, M. N. A. Efficiency of hydrogen internal combustion engine combined with open steam Rankine cycle recovering water and waste heat. International Journal of Hydrogen Energy, v. 35, n. 3, p. 1430-1442, 2010.

20 STOLTEN, D. Hydrogen and fuel cells: fundamental, technologies and applications. New York: WILEY-VCH, 2010. p. 63.

21 SCHONFELD, E. John Doerr On Bloom Energy Launch: "This Is Like The Google IPO". The Washington Post, 2010. Disponível em: < http://www.washingtonpost.com/wpdyn/content/article/2010/02/24/AR2010022403400.html >. Acesso em: 27 mar. 2013.

22 MEHTA, V.; COOPER, J. S. Review and analysis of PEM fuel cell design and manufacturing. Journal of Power Sources, v. 114, n. 1, p. 32-53, 2003.

23 BRAUN, P. V.; CHO, J. PIKUL, J.; JAMES, H; KING, W. P.; ZHANG, H. High power rechargeable batteries. Current Opinion in Solid State and Materials Science, v. 16, n. 4, p. 186-198, 2012.

24 WANG, Y.; CHEN, K. S.; MISHLER,J.; CHO, S. C.; ADROHER, X. C. A review of polymer electrolyte membrane fuel cells: Technology, applications, and needs on fundamental research. Applied Energy, v. 88, n. 4, p. 981-1007, 2011.

25 LEGER, J.; ROUSSEAU, S.; COUTANCEAU, C.; HAHN, F.; LAMY, C. How bimetallic electrocatalysts does work for reactions involved in fuel cells?Example of ethanol oxidation and comparison to methanol. Electrochimica Acta, v. 50, n. 2526, p. 5118-5125, 2005. 
26 RAMASAMY MANOHARAN, J. P. Possibilities of prevention of formation of poisoning species on direct methanol fuel cell anodes. Journal of Power Sources, v. 96, p. 220-225, 2001.

27 ANTOLINI, E. Catalysts for direct ethanol fuel cells. Journal of Power Sources, v. 170, n. 1, p. 1-12, 2007.

28 JABLONSKI, A.; LEWERA, A. Electrocatalytic oxidation of ethanol on Pt, Pt-Ru and Pt-Sn nanoparticles in polymer electrolyte membrane fuel cell-Role of oxygen permeation. Applied Catalysis B: Environmental, v. 115-116, p. 25-30, 2012.

29 PURGATO, F. L. S.; PRONIER, S.; OLIVI, P.; ANDRADE, A. R.; LÉGER, J. M.; TREMILIOSI-FILHO, G.; KOKOH, K. B. Direct ethanol fuel cell: Electrochemical performance at $90^{\circ} \mathrm{C}$ on Pt and PtSn/C electrocatalysts. Journal of Power Sources, v. 198, p. 95-99, 2012.

30 VIELSTICH, W.; PAGANIN, V. A.; ALVES, O. B.; CIAPINA, E. G. On the pathways of methanol and ethanol oxidation. In: VIELSTICH, W.;YOKOKAWA, H.; GESTEIGER, H. A. (Ed.). Handbook of fuel cells: fundamentals, technology and applications. New York: John Wiley, 2009. v.5, p.174-182.

31 METHANOL INSTITUTE. Methanol to hydrogen fueling stations. 2003.

Disponível em: <http://www.fuelcellmarkets.com/content/images/articles/methanol-tohydrogen.pdf>. Acesso em: 30 jun. 2013.

32 MIDILLI, A.; AY, M.; DINCER, I.; ROSEN, M. A. On hydrogen and hydrogen energy strategies. Renewable and Sustainable Energy Reviews, v. 9, n. 3, p. 255271, 2005.

33 HULTMAN, M.; YARAS, A. The socio-technological history of hydrogen and fuel cells in Sweden 1978-2005; mapping the innovation trajectory. International

Journal of Hydrogen Energy, v. 37, n. 17, p. 12043-12053, 2012.

34 BOCKRIS, J. O. M. The hydrogen economy: Its history. International Journal of Hydrogen Energy, v. 38, n. 6, p. 2579-2588, 2013.

35 ABBAS, H. F.; WAN DAUD, W. M. A. Hydrogen production by methane decomposition: A review. International Journal of Hydrogen Energy, v. 35, n. 3, p. 1160-1190, 2010.

36 LUTZ, A. E.; BRADSHAW, R. W.; KELLER, J. O.; WITMER, D. E. Thermodynamic analysis of hydrogen production by steam reforming. International Journal of Hydrogen Energy, v. 28, p. 159-167, 2003.

37 CHENG, X.; SHI, Z.; GLASS, N.; ZHANG, L.; ZHANG, J.; SONG, D.; LIU, Z.; WANG, H.; SHEN,J. A review of PEM hydrogen fuel cell contamination: Impacts, mechanisms, and mitigation. Journal of Power Sources, v. 165, n. 2, p. 739-756, 2007. 
38 POSTOLE, G.; AUROUX, A. The poisoning level of Pt/C catalysts used in PEM fuel cells by the hydrogen feed gas impurities: The bonding strength. International Journal of Hydrogen Energy, v. 36, n. 11, p. 6817-6825, 2011.

39 WEE, J.-H.; LEE, K.-Y. Overview of the development of CO-tolerant anode electrocatalysts for proton-exchange membrane fuel cells. Journal of Power Sources, v. 157, n. 1, p. 128-135, 2006.

40 SANTIAGO, E. I.; CAMARA, G. A.; TICIANELLI, E. A. CO tolerance on PtMo/C electrocatalysts prepared by the formic acid method. Electrochimica Acta, v. 48, n. 23, p. 3527-3534, 2003.

41 SANTIAGO, E. I.; PAGANIN, V. A.; DO CARMO, M.; GONZALEZ, E. R.; TICIANELLI, E. A. Studies of CO tolerance on modified gas diffusion electrodes containing ruthenium dispersed on carbon. Journal of Electroanalytical Chemistry, v. 575, n. 1, p. 53-60, 2005.

42 LOPES, P. P.; TICIANELLI, E. A. The CO tolerance pathways on the Pt-Ru electrocatalytic system. Journal of Electroanalytical Chemistry, v. 644, n. 2, p. 110-116, 2010.

43 EHTESHAMI, S. M. M.; CHAN, S. H. A review of electrocatalysts with enhanced $\mathrm{CO}$ tolerance and stability for polymer electrolyte membarane fuel cells.

Electrochimica Acta, v. 93, p. 334-345, 2013.

44 PEREIRA, L. G. S.; PAGANIN, V. A.; TICIANELLI, E. A. Investigation of the CO tolerance mechanism at several Pt-based bimetallic anode electrocatalysts in a PEM fuel cell. Electrochimica Acta, v. 54, n. 7, p. 1992-1998, 2009.

45 PANAGIOTOPOULOU, P.; KONDARIDES, D. I.; VERYKIOS, X. E. Selective methanation of $\mathrm{CO}$ over supported Ru catalysts. Applied Catalysis B:

Environmental, v. 88, n. 3-4, p. 470-478, 2009.

46 PANAGIOTOPOULOU, P.; KONDARIDES, D. I.; VERYKIOS, X. E. Selective methanation of $\mathrm{CO}$ over supported noble metal catalysts: Effects of the nature of the metallic phase on catalytic performance. Applied Catalysis A: General, v. 344, n. 12, p. 45-54, 2008.

47 DAGLE, R. A.; WANG, Y.; XIA, G.; STROHM, J. J.; HOLLADAY, J.; PALO, D. R. Selective $\mathrm{CO}$ methanation catalysts for fuel processing applications. Applied Catalysis A: General, v. 326, n. 2, p. 213-218, 2007.

48 DJINOVIĆ, P.; GALLETTI, C.; SPECCHIA, S.; SPECCHIA, V. Ru-based catalysts for $\mathrm{CO}$ selective methanation reaction in H2-rich gases. Catalysis Today, v. 164, n. 1, p. 282-287, 2011.

49 JIMÉNEZ, V.; SÁNCHEZ, P.; PANAGIOTOPOULOU, P.; VALVERDE, J. L.; ROMERO, A. Methanation of $\mathrm{CO}, \mathrm{CO} 2$ and selective methanation of $\mathrm{CO}$, in mixtures of $\mathrm{CO}$ and $\mathrm{CO} 2$, over ruthenium carbon nanofibers catalysts. Applied Catalysis A: General, v. 390, n. 1-2, p. 35-44, 2010. 
50 BATISTA, M. S.; SANTIAGO, E. I.; ASSAF, E. M.; TICIANELLI, E. A. Evaluation of the water-gas shift and $\mathrm{CO}$ methanation processes for purification of reformate gases and the coupling to a PEM fuel cell system. Journal of Power Sources, v. 145, n. 1, p. 50-54, 2005.

51 GALLETTI, C.; SPECCHIA, S.; SARACCO, G.; SPECCHIA, V. CO-selective methanation over $\mathrm{Ru}-\mathrm{YAl}_{2} \mathrm{O}_{3}$ catalysts in $\mathrm{H}_{2}$-rich gas for PEMFC applications.

Chemical Engineering Science, v. 65, n. 1, p. 590-596, 2010.

52 GALLETTI, C.; SPECCHIA, S.; SPECCHIA, V. CO selective methanation in H2rich gas for fuel cell application: Microchannel reactor performance with Ru-based catalysts. Chemical Engineering Journal, v. 167, n. 2-3, p. 616-621, 2011.

53 ECKLE, S.; AUGUSTIN, M.; ANFANG, H.; BEHM, R. J. Influence of the catalyst loading on the activity and the CO selectivity of supported Ru catalysts in the selective methanation of $\mathrm{CO}$ in $\mathrm{CO} 2$ containing feed gases. Catalysis Today, v. 181, n. 1, p. 40-51, 2012.

54 KIM, Y. H.; PARK, E. D.; LEE, H. C.; LEE, D. Selective CO removal in a $\mathrm{H}_{2}$-rich stream over supported Ru catalysts for the polymer electrolyte membrane fuel cell (PEMFC). Applied Catalysis A: General, v. 366, n. 2, p. 363-369, 2009.

55 GONZALEZ, E. R.; TICIANELLI, E. A.; PINHEIRO, A. L. N.; PEREZ, J. Processo de obtenção de catalisador de platina ancorada em substrato através da redução por ácido. BR n. PI9702816-9, 02 set. 1997.

56 ROLISON, D. R.; HAGANS, P. L.; SWIDER, K. E.; LONG, J. W. Role of hydrous ruthenium oxide in Pt-Ru direct methanol fuel cell anode electrocatalysts: The importance of mixed electron/proton conductivity. Langmuir, v. 15, n. 3, p. 774-779, 1999.

57 LONG, J. W.; STROUD, R. M.; SWIDER, K. E.; ROLISON, D. R. How to make electrocatalysts more active for direct methanol oxidation - avoid PtRu bimetallic alloys! Journal of Physical Chemistry B, v. 104, n. 42, p. 9772-9776, 2000.

58 LOPES, P. P.; TICIANELLI, E. A.; VARELA, H. Potential oscillations in a proton exchange membrane fuel cell with a Pd-Pt/C anode. Journal of Power Sources, v. 196, n. 1, p. 84-89, 2011.

59 LOPES, T.; ANTOLINI, E.; COLMATI, F.; GONZALEZ, E. R. Carbon supported Pt-Co (3:1) alloy as improved cathode electrocatalyst for direct ethanol fuel cells. Journal of Power Sources, v. 164, n. 1, p. 111-114, 2007.

60 LOPES, T.; ANTOLINI, E.; GONZALEZ, E. Carbon supported Pt-Pd alloy as an ethanol tolerant oxygen reduction electrocatalyst for direct ethanol fuel cells.

International Journal of Hydrogen Energy, v. 33, n. 20, p. 5563-5570, 2008. 
61 MILLINGTON, B.; WHIPPLE, V.; POLLET, B. G. A novel method for preparing proton exchange membrane fuel cell electrodes by the ultrasonic-spray technique. Journal of Power Sources, v. 196, n. 20, p. 8500-8508, 2011.

62 PARK, G.-G.; SOHN, Y.-J.; YANG, T.-H.; YOON, Y.-G.; LEE, W.-Y.; KIM, C.-S. Effect of PTFE contents in the gas diffusion media on the performance of PEMFC. Journal of Power Sources, v. 131, n. 1-2, p. 182-187, 2004.

63 PAGANIN, V. A.; TICIANELLI, E. A.; GONZALEZ, E. R. Development and electrochemical studies of gas diffusion electrodes for polymer electrolyte fuel cells. Journal of Applied Electrochemistry, v. 26, n. 3, p. 297-304, 1996.

64 MILLER, J. C.; MILLER, J. N. Estadística y quimiometría para química analítica. Madri: Pearson Education, 2008. p. 152.

65 MOHANTY, P.; PATEL, M.; PANT, K. K. Hydrogen production from steam reforming of acetic acid over $\mathrm{Cu}-\mathrm{Zn}$ supported calcium aluminate. Bioresource Technology, v. 123, p. 558-65, 2012.

66 PIRES, F. I.; CORRADINI, P. G.; PAGANIN, V. .A.; ANTOLINI, E.; PEREZ, J. Effect of the degree of alloying of PtRu/C (1:1) catalysts on ethanol oxidation. Ionics, v. 19, n. 7 , p. 1037-1045, 2012.

67 MONTIEL, M.; HERNÁNDEZ-FERNÁNDEZ, P.; FIERRO, J. L. G.; ROJAS, S.; OCÓN, P. Promotional effect of upper Ru oxides as methanol tolerant electrocatalyst for the oxygen reduction reaction. Journal of Power Sources, v. 191, n. 2, p. 280288, 2009.

68 SALGADO, J. R. C.; FERNANDES, J. C. S.; BOTELHO, A. M.; FERRARIA, A. M.; DUARTE, R. G.; FERREIRA, M. G. S. Pt-Ru nanoparticles supported on functionalized carbon as electrocatalysts for the methanol oxidation. Electrochimica Acta, v. 56, n. 24, p. 8509-8518, 2011.

69 ANTONETTI, C.; OUBENALI, M.; RASPOLLI, A. M. G.; SERP, P.; VANUCCI, G. Novel microwave synthesis of ruthenium nanoparticles supported on carbon nanotubes active in the selective hydrogenation of $p$-chloronitrobenzene to $p$ chloroaniline. Applied Catalysis A: General, v. 421-422, p. 99-107, 2012.

70 HSIEH, T.-F.; CHUANG, C.-C.; CHEN, W.-J.; HUANG, J.-H.; CHEN, W.-T.; SHU, C.-M. Hydrous ruthenium dioxide/multi-walled carbon-nanotube/titanium electrodes for supercapacitors. Carbon, v. 50, n. 5, p. 1740-1747, 2012.

71 SCHOUTEN, K. J. P.; KWON, Y.; HAM, C. J. M.; QIN, Z.; KOPER, M. T. M. A new mechanism for the selectivity to $\mathrm{C} 1$ and $\mathrm{C} 2$ species in the electrochemical reduction of carbon dioxide on copper electrodes. Chemical Science, v. 2, n. 10, p. 1902, 2011.

72 PANAGIOTOPOULOU, P.; KONDARIDES, D. I.; VERYKIOS, X. E. Mechanistic aspects of the selective methanation of $\mathrm{CO}$ over Ru/TiO2 catalyst. Catalysis Today, v. 181, n. 1, p. 138-147, 2012. 
73 DAVIES, J. C.; TSOTRIDIS, G. Temperature-dependent kinetic study of CO desorption from Pt PEM fuel cell anodes. Journal of Physical Chemistry C, v. 112, p. 3392-3397, 2008.

74 KIM, S. S.; PARK, K. H.; HONG, S. C. A study of the selectivity of the reverse water-gas-shift reaction over Pt/TiO2 catalysts. Fuel Processing Technology, v. 108, p. 47-54, 2013. 